Prepared in cooperation with Eagle River Watershed Council

\title{
Assessment of Diel Cycling in Nutrients and Trace Elements in the Eagle River Basin, 2017-18
}
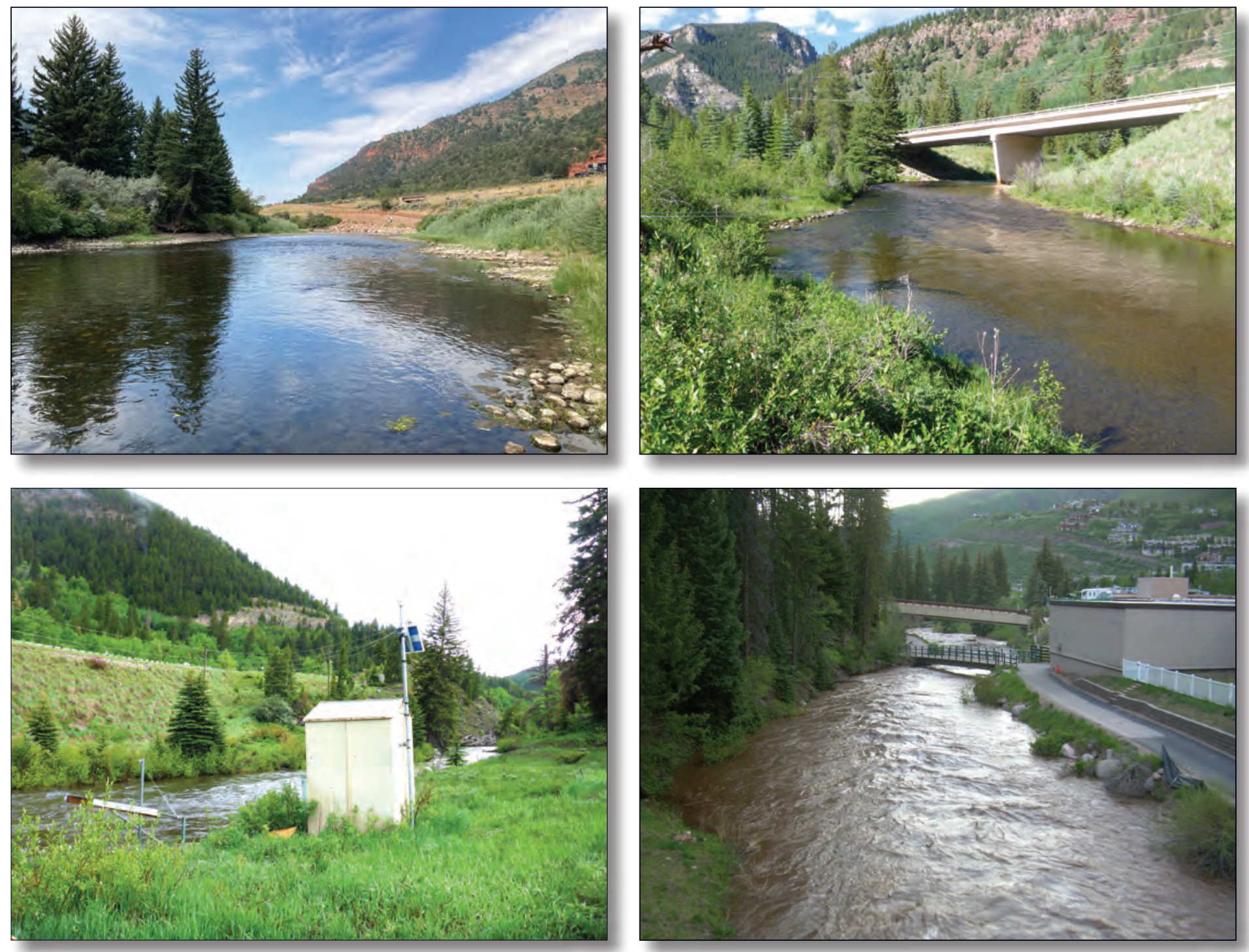

Scientific Investigations Report 2021-5066 
Cover. Eagle River near Minturn, Colo., looking upstream. [Photograph by U.S. Geological Survey, June 18, 2019] Eagle River near Minturn, Colo., looking downstream. [Photograph by U.S. Geological Survey, June 25, 2018] Gore Creek above Red Sandstone Creek at Vail, Colo., looking downstream. [Photograph by U.S. Geological Survey, May 26, 2006] Eagle River below Milk Creek near Wolcott, Colo., looking downstream. [Photograph by U.S. Geological Survey, August 27, 2020] 


\section{Assessment of Diel Cycling in Nutrients and Trace Elements in the Eagle River Basin, 2017-18}

By Rodney J. Richards and Mark F. Henneberg

Prepared in cooperation with Eagle River Watershed Council

Scientific Investigations Report 2021-5066 


\section{U.S. Geological Survey, Reston, Virginia: 2021}

For more information on the USGS - the Federal source for science about the Earth, its natural and living resources, natural hazards, and the environment—visit https://www.usgs.gov or call 1-888-ASK-USGS.

For an overview of USGS information products, including maps, imagery, and publications, visit https://store.usgs.gov/.

Any use of trade, firm, or product names is for descriptive purposes only and does not imply endorsement by the U.S. Government.

Although this information product, for the most part, is in the public domain, it also may contain copyrighted materials as noted in the text. Permission to reproduce copyrighted items must be secured from the copyright owner.

Suggested citation:

Richards, R.J., and Henneberg, M.F., 2021, Assessment of diel cycling in nutrients and trace elements in the Eagle River Basin, 2017-18: U.S. Geological Survey Scientific Investigations Report 2021-5066, 36 p., https://doi.org/10.3133/sir20215066.

Associated data for this publication: U.S. Geological Survey, 2019a, USGS water data for the Nation: U.S. Geological Survey National Water Information System database, accessed June 2019, https://doi.org/10.5066/F7P55KJN.

U.S. Geological Survey, 2019b, USGS 09065500 Gore Creek at upper Station, near Minturn, CO, in USGS water data for the Nation: U.S. Geological Survey National Water Information System database, accessed May 23, 2019, at https://doi.org/10.5066/F7P55KJN.

U.S. Geological Survey, 2019c, USGS 09063000 Eagle River at Redcliff, CO, in USGS water data for the Nation: U.S. Geological Survey National Water Information System database, accessed May 23, 2019, at https://doi.org/10.5066/F7P55KJN.

ISSN 2328-0328 (online) 


\section{Acknowledgments}

The authors wish to thank the Eagle River Watershed Council for funding this study and Eagle County for acting as the fiscal agent. The authors want to express gratitude to Robert Runkel (U.S. Geological Survey) for providing technical assistance and guidance. 



\section{Contents}

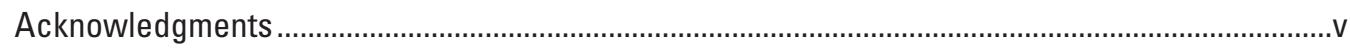

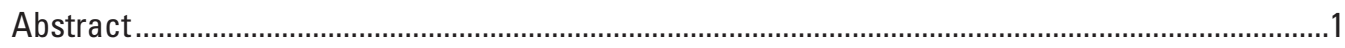

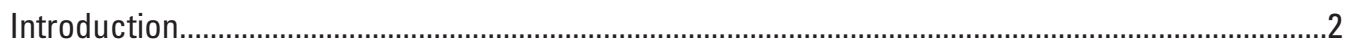

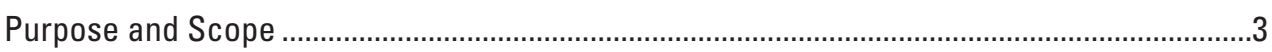

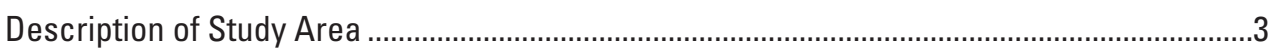

Mechanisms of Diel Cycling .........................................................................................

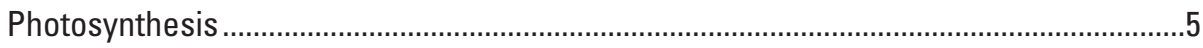

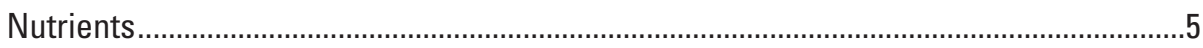

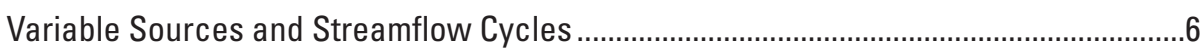

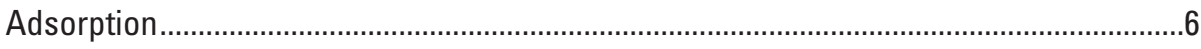

Importance of Iron and Manganese Reactions..................................................................

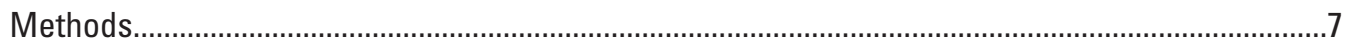

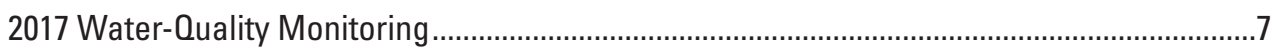

2018 Water-Quality Data Collection .....................................................................................

Evaluation of 2017 Water-Quality Monitor Data.........................................................................

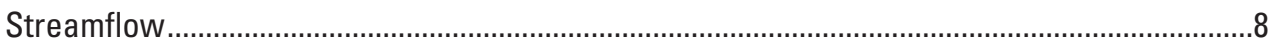

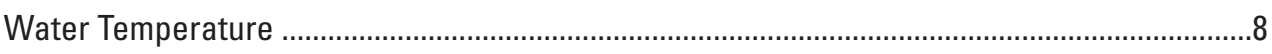

Specific Conductance ................................................................................................. 10

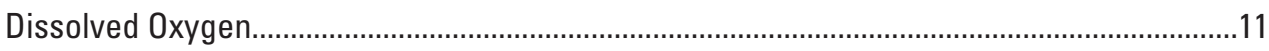

$\mathrm{pH}$

Photosynthetically Active Radiation................................................................................

Overview of 2017 Diel Patterns........................................................................................12

Assessment of Diel Cycling in Nutrient and Trace-Element Concentrations ..................................12

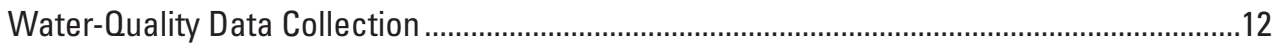

Quality Assurance and Quality Control ...............................................................................13

Water-Quality Properties.....................................................................................................

Diel Cycle and Magnitude in Nutrients ..............................................................................

Diel Cycle and Magnitude in Trace Elements .....................................................................17

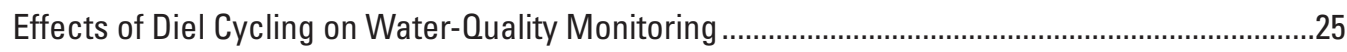

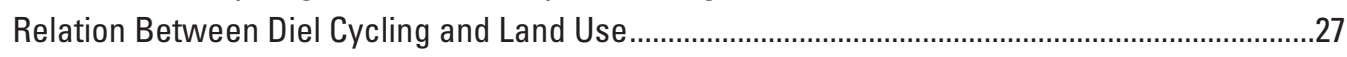

Summary

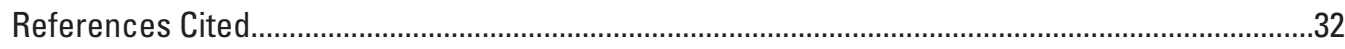

\section{Figures}

1. Map showing location of five water-quality sampling sites along the Eagle River and Gore Creek used to assess diel cycling, Eagle County, Colorado

2. Graphs showing 2017 variation in water temperature, $\mathrm{pH}$, streamflow, specific conductance, dissolved oxygen, photosynthetically active radiation, and daily average photosynthetically active radiation at site $A, 09065500, B, 09066325, C$, zoomed in specific conductance and streamflow at site $09066325, D, 09063000$, $E, 09064600$, and $F, 394220106431500$ 
3. Graphs showing diel variation of $\mathrm{pH}$, carbon dioxide, dissolved oxygen, and water temperature during water-quality sample collection September 5-11, 2018, at sites $A, 09064600, B, 09066325$, and $C, 394220106431500$, Eagle County, Colorado

4. Graphs showing water-quality monitoring data measured in August and September 2018, in conjunction with water-quality sampling at sites $A$, 09064600, B, 09066325, and C, 394220106431500, Eagle County, Colorado

5. Graph showing filtered nitrate plus nitrite concentrations and $A, \mathrm{pH}$, $B$, dissolved oxygen, and $C$, streamflow measurements from water-quality samples collected September 10-11, 2018, at site 394220106431500, Eagle County, Colorado.

6. Graphs showing diel variation of filtered zinc, filtered manganese, and total recoverable iron in water-quality samples collected at sites $A, 09064600$ and $B, 394220106431500$ from September 10-11, 2018, Eagle County, Colorado

7. Graphs showing diel variation of filtered manganese and zinc in relation to $\mathrm{pH}$, dissolved oxygen, and streamflow measured in relation to water-quality samples collected at sites $A, 09064600$ and $B, 394220106431500$ from September 10-11, 2018, Eagle County, Colorado.

8. Graph showing comparison of total manganese and filtered manganese concentrations in water-quality samples collected September 10-11, 2018, at site 394220106431500, Eagle County, Colorado

9. Graphs showing frequency of historical water-quality samples in terms of time of day at sites $A, 09064600$ and $B, 394220106431500$ with sampling results from September 2018 included, Eagle County, Colorado.

10. Graphs showing median historical filtered manganese, filtered zinc, and filtered nitrate plus nitrite concentration each hour for historical samples collected from July through October at sites $A, 09064600$ and $B, 394220106431500$, Eagle County, Colorado.

11. Map showing land use in the Eagle River Basin, Eagle County, Colorado .......................28

12. Graphs showing water-quality monitoring data from September 10 September 12, 2017, comparing pH, dissolved oxygen, and water temperature at sites $A, 09065500$ and $B, 394220106431500$, Eagle County, Colorado..

\section{Tables}

1. Sites in the Eagle River Basin assessed for diel cycling in nutrients and trace elements, Eagle County, Colorado..

2. Summary of 2017 water-quality monitoring deployments at five sites in the Eagle River Basin, Eagle County, Colorado

3. Results of sample-replicate analysis during September 2018 water-quality sampling, Eagle County, Colorado...

4. Summary of water-quality properties collected with water-quality samples in September 2018, Eagle County, Colorado

5. Summary of nutrient data collected at three sites in the Eagle River Basin, September 2018, Eagle County, Colorado

6. Summary of trace-element data collected at three sites in the Eagle River Basin, September 2018, Eagle County, Colorado. 


\section{Conversion Factors}

U.S. customary units to International System of Units

\begin{tabular}{|c|c|c|}
\hline Multiply & By & To obtain \\
\hline \multicolumn{3}{|c|}{ Length } \\
\hline inch (in.) & 2.54 & centimeter $(\mathrm{cm})$ \\
\hline inch (in.) & 25.4 & millimeter $(\mathrm{mm})$ \\
\hline mile (mi) & 1.609 & kilometer (km) \\
\hline \multicolumn{3}{|c|}{ Area } \\
\hline acre & 4,047 & square meter $\left(\mathrm{m}^{2}\right)$ \\
\hline square mile $\left(\mathrm{mi}^{2}\right)$ & 2.590 & square kilometer $\left(\mathrm{km}^{2}\right)$ \\
\hline \multicolumn{3}{|c|}{ Volume } \\
\hline gallon (gal) & 3.785 & liter $(\mathrm{L})$ \\
\hline \multicolumn{3}{|c|}{ Flow rate } \\
\hline cubic foot per second $\left(\mathrm{ft}^{3} / \mathrm{s}\right)$ & 0.02832 & cubic meter per second $\left(\mathrm{m}^{3} / \mathrm{s}\right)$ \\
\hline \multicolumn{3}{|c|}{ Mass } \\
\hline kilogram (kg) & 2.205 & pound avoirdupois (lb) \\
\hline
\end{tabular}

Temperature in degrees Celsius $\left({ }^{\circ} \mathrm{C}\right)$ may be converted to degrees Fahrenheit $\left({ }^{\circ} \mathrm{F}\right)$ as follows: ${ }^{\circ} \mathrm{F}=\left(1.8 \times{ }^{\circ} \mathrm{C}\right)+32$.

Temperature in degrees Fahrenheit $\left({ }^{\circ} \mathrm{F}\right)$ may be converted to degrees Celsius $\left({ }^{\circ} \mathrm{C}\right)$ as follows:

$$
{ }^{\circ} \mathrm{C}=\left({ }^{\circ} \mathrm{F}-32\right) / 1.8 \text {. }
$$

\section{Datum}

Vertical coordinate information is referenced to the [North American Vertical Datum of 1988 (NAVD 88)].

Horizontal coordinate information is referenced to the [North American Datum of 1983 (NAD 83)]. Altitude, as used in this report, refers to distance above the vertical datum.

\section{Supplemental Information}

Specific conductance is given in microsiemens per centimeter at 25 degrees Celsius $(\mu \mathrm{S} / \mathrm{cm}$ at $\left.25^{\circ} \mathrm{C}\right)$.

Concentrations of chemical constituents in water are given in either milligrams per liter (mg/L) or micrograms per liter $(\mu \mathrm{g} / \mathrm{L})$.

Streamflow is given in cubic feet per second $\left(\mathrm{ft}^{3} / \mathrm{s}\right)$. 


\section{Abbreviations}

\begin{tabular}{ll}
$<$ & less than \\
$>$ & greater than \\
${ }^{\circ} \mathrm{C}$ & degrees Celsius \\
${ }^{\circ} \mathrm{F}$ & degrees Fahrenheit \\
$\mathrm{ft} 3 / \mathrm{s}$ & cubic feet per second \\
$\mathrm{Cd}$ & Cadmium \\
$\mathrm{Cu}$ & Copper ${ }^{2+}$ \\
$\mathrm{in}$. & inch \\
$\mathrm{Mn}$ & Manganese \\
$\mu \mathrm{g} / \mathrm{L}$ & micrograms per liter \\
$\mu \mathrm{m}$ & micrometer \\
$\mu \mathrm{S} / \mathrm{cm}$ & microsiemens per centimeter \\
$\mathrm{mg} / \mathrm{L}$ & milligrams per liter \\
$\mathrm{mi}{ }^{2}$ & square mile \\
$\mu \mathrm{mol} / \mathrm{m}{ }^{2} / \mathrm{s}$ & micromoles per square meter per second \\
$\mathrm{NWIS}$ & National Water Information System \\
$\mathrm{N}$ & Nitrogen \\
$\mathrm{P}$ & Phosphorus \\
$\mathrm{PAR}$ & Photosynthetically Active Radiation \\
$\mathrm{RPD}$ & Relative Percent Difference \\
$\mathrm{QA} / \mathrm{OC}$ & Quality Assurance/Quality Control \\
$\mathrm{USGS}$ & U.S. Geological Survey \\
$\mathrm{Zn}$ & zinc \\
\hline
\end{tabular}




\title{
Assessment of Diel Cycling in Nutrients and Trace Elements in the Eagle River Basin, 2017-18
}

\author{
By Rodney J. Richards and Mark F. Henneberg
}

\section{Abstract}

Diel cycles are known to occur in all types of waters, and increasing studies indicate routine water samples may not provide an accurate snapshot in concentrations of trace elements and nutrients. Diel behavior in neutral to alkaline $\mathrm{pH}$ ranges is independent of streamflow variability and concentration. Extensive historical U.S. Geological Survey (USGS) water-quality data have been collected in the Eagle River Basin during daylight hours, which is defined as the period of time between one-half hour prior to sunrise and one-half hour after sunset. However, no USGS data have been collected throughout the nighttime, defined as the time between one-half hour after sunset and one-half hour prior to sunrise, making the evaluation of diel cycles impossible. To assess the importance of diel cycling within the Eagle River Basin, the USGS, in cooperation with Eagle River Watershed Council, developed a study to assess the mechanisms, patterns, and magnitude of change during the diel cycle for selected constituents. Water-quality monitors at five USGS streamgage sites (09065500, Gore Creek at Upper Station, near Minturn, Colorado, 09063000, Eagle River at Red Cliff, Colorado, 09064600, Eagle River near Minturn, Colorado, 09066325, Gore Creek above Red Sandstone Creek at Vail, Colorado, and 394220106431500, Eagle River below Milk Creek near Wolcott, Colorado) were deployed in 2017 to evaluate the water-quality field parameters and to determine if water conditions were favorable for the diel cycling of nutrients and trace elements. Based on the evaluation of water-quality parameters, three of the five sites were sampled for nutrient and traceelement concentrations in 2018 to confirm the presence and magnitude of diel cycling. Historical data were also analyzed to assess the effect of time of day on measured nutrient and trace-element concentrations. An assessment of the effect of land use on diel cycling was also investigated.

Measurable nutrients displayed a diel cycle at all three sites with the largest percentage change at the most downstream site (394220106431500), located on the Eagle River. More notable diel cycles at this site include filtered nitrate plus nitrite, which varied 179 percent, with concentrations from 0.24 to 0.67 milligrams per liter $(\mathrm{mg} / \mathrm{L})$ and filtered orthophosphate, which varied 71 percent, with concentrations from 0.07 to $0.12 \mathrm{mg} / \mathrm{L}$. Filtered nitrate plus nitrite at site 09066325 varied 57 percent, ranging from 0.14 to $0.22 \mathrm{mg} / \mathrm{L}$. Maximum concentrations occurred prior to noon, decreased through the afternoon (between noon and sunset), and increased during the night (between sunset and sunrise). That pattern is consistent with nutrient uptake in response to daytime (between sunrise and sunset) photosynthesis along with biologically driven denitrification and nitrification cycles. Nutrient concentrations at sites 09064600 and 09066325 were generally low and below laboratory reporting limits, which is the smallest measured concentration that nutrients could be measured by a given analytical method.

Trace-element concentrations were detectable at all sites with the largest percentage change at the most downstream site (394220106431500) and exhibited diel concentration variation from 11.6 to 284 percent. Appreciable diel cycles included filtered copper (0.98-1.40 micrograms per liter $[\mu \mathrm{g} / \mathrm{L}], 42.9$ percent), filtered zinc (less than $[<]$ $4.00-5.50 \mu \mathrm{g} / \mathrm{L}$, greater than $[>] 37.5$ percent), total manganese $(9.70-19.5 \mu \mathrm{g} / \mathrm{L}, 101$ percent), and total arsenic $(0.30-0.40 \mu \mathrm{g} / \mathrm{L}, 33.3$ percent $)$. The largest percentage change in concentration was filtered manganese $(2.84-10.9 \mu \mathrm{g} / \mathrm{L}$, 284 percent). Diel cycles at site 09064600 ranged from 9.1 to 64.5 percent across the trace elements measured. Dissolved trace elements with appreciable diel cycles during the sampling period include filtered cadmium $(0.09-0.12 \mu \mathrm{g} / \mathrm{L}$, 33.3 percent $)$, filtered copper $(0.99-1.40 \mu \mathrm{g} / \mathrm{L}, 41.4$ percent $)$, and total arsenic $(0.20-0.30 \mu \mathrm{g} / \mathrm{L}, 50$ percent $)$. The largest percentage change was filtered zinc $(38.3-63.0 \mu \mathrm{g} / \mathrm{L}$, 65 percent). Trace-element concentrations at site 09066325 were below laboratory reporting limits for many parameters, and no diel cycle could be assessed for these parameters. However, total recoverable iron, filtered barium, filtered manganese, and filtered selenium exhibited changes in concentrations of $<10.0-19.4 \mu \mathrm{g} / \mathrm{L}(>94$ percent $)$, $115-121 \mu \mathrm{g} / \mathrm{L}$ (5 percent), $1.44-1.72 \mu \mathrm{g} / \mathrm{L}$ (19.4 percent), and $0.25-0.28 \mu \mathrm{g} / \mathrm{L}$ (12 percent), respectively. At sites 09064600 and 394220106431500, maximum trace-element concentrations occurred during nighttime with some variation regarding the timing of the peak. The exceptions to this were filtered copper, total arsenic, and filtered selenium, which had maximum concentrations around noon or as the sun disappeared below the horizon. The timing of minimum concentrations occurred in the afternoon for many trace elements, with 
filtered copper, total arsenic, and filtered selenium having minimum concentrations in the morning or just prior to the appearance of the sun.

Analysis of historical data also showed evidence of diel cycling. Historical samples collected from July through October were used to identify diel cycling in base-flow conditions. The resulting diel pattern in the median concentration for filtered manganese, filtered zinc at water-quality site 09064600 , and filtered manganese and filtered nitrate plus nitrite at water-quality site 39422016431500 were consistent with the diel pattern in the September 2018 samples, and indicate time of day can bias sampling results even during daylight hours.

Diel cycling in the Eagle River Basin appears to be driven primarily by instream, biological processes. However, land use, particularly human effects downstream from urban areas, mining, and agriculture, may affect these processes. At some locations, diel variations in nutrient and trace-element concentrations are small enough to be of low concern. At other locations, however, variations in concentrations up to 284 percent in the data collected for this study and 214 percent in base-flow historical data, indicate daytime-only sampling, particularly in late afternoon, can underestimate daily average nutrient and trace-element concentrations. When feasible, the potential of diel cycling warrants consideration in sample design to account for the potential of diel cycles, or at a minimum, be recognized as a component of the river dynamic and the potential consequences that diel cycles may have in data interpretation and river management decisions.

\section{Introduction}

Previous investigations have documented the occurrence of daily fluctuations in the concentrations of dissolved constituents in various streams, known as diel cycling (Lorens, 1981; Fuller and Davis, 1989; Fuller and others, 1993;

Zachara and others, 1991; Tesoriero and Pankow, 1995; Fowle and Fein, 2000; Trivedi and Axe, 2000; Nimick and others, 2003; Nimick and others, 2011; Gammons and others, 2015). Diel cycles are known to occur in all types of waters; however, there has historically been more interest in streams and watersheds actively mined or undergone mitigation from mining activities. The traditional conclusion is one water sample collected during daylight hours, which is defined as the period of time between one-half hour prior to sunrise and one-half hour after sunset, provides an accurate snapshot of concentrations for that day. However, increasing studies now indicate concentrations of trace elements and nutrients can exhibit diel behavior in neutral to alkaline $\mathrm{pH}$ ranges independent of streamflow variability and concentration (Nimick and others, 2003; Nimick and others, 2011; Gammons and others, 2015).

Although useful in capturing a snapshot of the instream condition, periodic water-quality samples collected during daylight hours can be misleading and can potentially fail to capture the entire range of variability throughout the daylight and nighttime, defined as the time between one-half hour after sunset and one-half hour prior to sunrise, as is the case with positively charged trace elements, which have maximum values occurring at night. The occurrence and magnitude of diel cycling is important to understand as periodic water-quality samples are used to evaluate management strategies, establish baseline conditions, evaluate long-term trends, establish criteria for aquatic biota, and evaluate compliance of water-quality criteria (Nimick and others, 2003).

Diel cycles in stream systems are well documented. McKnight and others (1988) and Sullivan and others (1998) reported fluctuations in filtered iron in acidic mine drainage in Colorado. Fuller and Davis (1989) documented daily cycling of dissolved arsenic in Whitewood Creek, South Dakota, which is a mined watershed with tailing piles. They attributed the approximate 40 percent change in arsenic concentration to cycles in $\mathrm{pH}$ as a result of photosynthesis and the resulting shift in adsorption and desorption response. Nimick and others (1998) documented a 20 percent change in arsenic downstream from natural sources of arsenic in Yellowstone National Park. Both studies recognized diel cycles in arsenic appear to be offset from the peak in $\mathrm{pH}$, and the highest concentrations were observed in the late afternoon. Bourg and Bertin (1996) and Brick and Moore (1996) appear to be the first to document divalent metals exhibiting diel cycles in alkaline streams. Data from the Clark Fork in Montana demonstrated dissolved manganese and zinc concentrations have diel cycles; the Lot River in France also exhibited diel cycling in dissolved zinc. Both reports documented highest concentrations in the early morning hours. Nimick and others (2003) documented diel cycling of numerous trace elements including arsenic, cadmium, copper, manganese, nickel, and zinc in historical mine-affected areas in Montana and Idaho. Diel cycles of the different metals all varied in magnitude; however, some metals exhibited changes in concentrations up to 300 percent during the day. In more recent studies, Gammons and others (2015) built on the previous knowledge base and demonstrated many trace elements exhibit diel patterns. In neutral and alkaline systems, both cationic and anionic elements tend to exhibit diel cycles, whereas in acidic streams, iron tends to be the primary element exhibiting diel cycling.

Extensive historical water-quality data exist in the Eagle River Basin; however, no samples have been collected during a 24-hour cycle, making the evaluation of diel cycles impossible. To assess the importance of diel cycling within the Eagle River Basin, the U.S. Geological Survey (USGS) - in cooperation with Eagle River Watershed Council—conducted a study to monitor diel cycles of water-quality properties at multiple locations within the Eagle River Basin. Five selected sites were monitored using multiparameter water-quality sondes, and water-quality samples were collected at three of the five sites during a 24-hour period to determine existence and magnitude of diel variability. 


\section{Purpose and Scope}

This purpose of this report is to characterize data describing diel cycles in water-quality properties, nutrients, and select trace-element concentrations during base-flow conditions at up to five sites within the Eagle River Basin from 2017 to 2018 (table 1). The sites were selected in part to assess the effect of land use (natural forest, mining affected, agricultural affected, and urban affected) on diel cycling, and extend from Red Cliff, Colorado, on the Eagle River; above Vail, Colorado, on Gore Creek to downstream from Wolcott, Colorado. USGS streamgage site 394220106431500 was selected to capture as much of the land-use types as possible to assess whether the magnitude of diel cycling of trace elements and nutrients varies across multiple land-use practices.

For the selected sites in the study area, in situ waterquality monitoring deployments occurred in summer and early fall 2017, and in September 2018. Discrete water-quality samples, consisting of samples collected every $4-5$ hours at 3 sites, were collected to assess the variability of waterquality properties, nutrients, and trace elements. This report (1) characterizes the diel variability and patterns in waterquality properties during the 2017 in situ water-quality monitoring deployments; (2) assesses and characterizes the diel variability in nutrients and trace elements; (3) assesses and compares patterns and diel cycles from discrete samples collected in 2018 to historical samples; (4) assesses the relation between observed diel cycles to land use within the basin.

\section{Description of Study Area}

The Eagle River, located in central Colorado, drains approximately 970 square miles $\left(\mathrm{mi}^{2}\right)$ before flowing into the Colorado River (Seaber and others, 1987). The headwaters originate in the southernmost region of the basin and flow northward until joining Gore Creek and then turning westward until terminating at the confluence with the Colorado River. The largest tributary, Gore Creek, drains approximately $100 \mathrm{mi}^{2}$, flowing westward through Vail, Colorado, and terminates near Minturn, Colorado, at the confluence with the Eagle River (fig. 1).
The air temperature and precipitation are typical of many basins in central and western Colorado. Monthly average air temperatures range from 5.7 degrees Fahrenheit $\left({ }^{\circ} \mathrm{F}\right)$ $\left(-14.6\right.$ degrees Celsius) to $77.7^{\circ} \mathrm{F}$ ( 25 degrees Celsius $)$ in the Vail area and from $3.6^{\circ} \mathrm{F}$ ( -15.8 degrees Celsius) to $85.4^{\circ} \mathrm{F}$ (29.7 degrees Celsius) in the area near Eagle, Colorado. Average annual precipitation ranges from 10.9 inches (in.) in the Eagle area to 22.4 inches in the Vail area. Much of the precipitation is in the form of snow in the winter months, averaging $48.0 \mathrm{in}$. in the Eagle area, and 183 in. in the Vail area along with occasional rain showers in the spring and late summer, early fall (Western Regional Climate Center, 2019). Streamflow is dictated primarily by snowmelt runoff in the late spring and normally peaks in late May or early June, followed by receding flows through the summer months. Base-flow conditions normally begin in late August or early September and persist until snowmelt begins the following year (U.S. Geological Survey, 2019a).

USGS streamgage 09065500, Gore Creek at Upper Station, near Minturn, Colorado, drains the main stem of Gore Creek upstream from most urban activity and has little human activity upstream from the site (fig. 1). Underlying geology is predominately Precambrian age granite with some potential glacial gravels and alluvium along the valley bottom (Tweto, 1979). The water-quality concerns at this site are minimal regarding trace elements and nutrients based on historical concentrations. Designated as a natural forest and background site for the study, the potential for diel effect was low based on historical concentrations sampled at the site. Trace elements and nutrients are typically below analytical detection limits (U.S. Geological Survey, 2019b).

USGS streamgage 09063000, Eagle River at Red Cliff, Colorado, is located on the upstream end of Red Cliff and drains the upper portion of the main stem Eagle River (fig. 1). The underlying geology is dominated by the Minturn formation, a mixture of arkosic sandstone, conglomerates, shale, and limestone; some isolated areas have glacial gravels and alluvium (Tweto, 1979). There is also minimal human activity upstream from this site, other than the former military base, Camp Hale, and limited water storage from the Climax Molybdenum Company mine near the headwaters. Also designated as a natural forest site for the study, the potential for diel effect was low based on historical concentration for trace elements and nutrients (U.S. Geological Survey, 2019c).

Table 1. Sites in the Eagle River Basin assessed for diel cycling in nutrients and trace elements, Eagle County, Colorado.

[USGS, U.S. Geological Survey; CO, Colorado; -, no information]

\begin{tabular}{|c|c|c|c|c|}
\hline $\begin{array}{c}\text { USGS } \\
\text { streamgage number }\end{array}$ & $\begin{array}{c}\text { USGS } \\
\text { streamgage name }\end{array}$ & $\begin{array}{l}\text { 4-parameter } \\
\text { monitor }\end{array}$ & $\begin{array}{l}\text { Sampling } \\
\text { date }\end{array}$ & $\begin{array}{l}\text { Time between } \\
\text { samples }\end{array}$ \\
\hline 09065500 & Gore Creek at upper Station, near Minturn, CO & Yes & - & - \\
\hline 09063000 & Eagle River at Redcliff, $\mathrm{CO}$ & Yes & - & - \\
\hline 09064600 & Eagle River near Minturn, CO & Yes & September 5-6, 2018 & $4-5$ hours \\
\hline
\end{tabular}




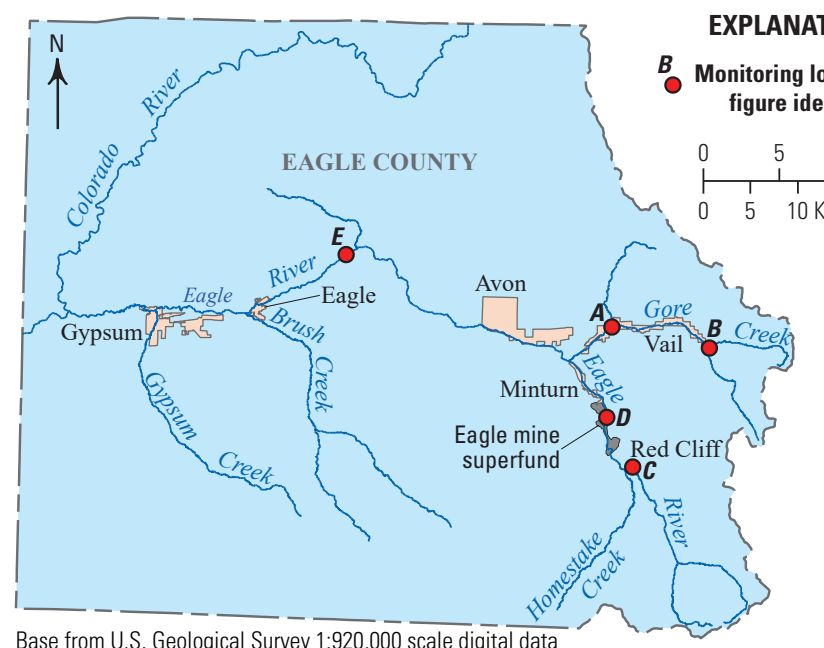

Base from U.S. Geological Survey 1:920,000 scale digital data
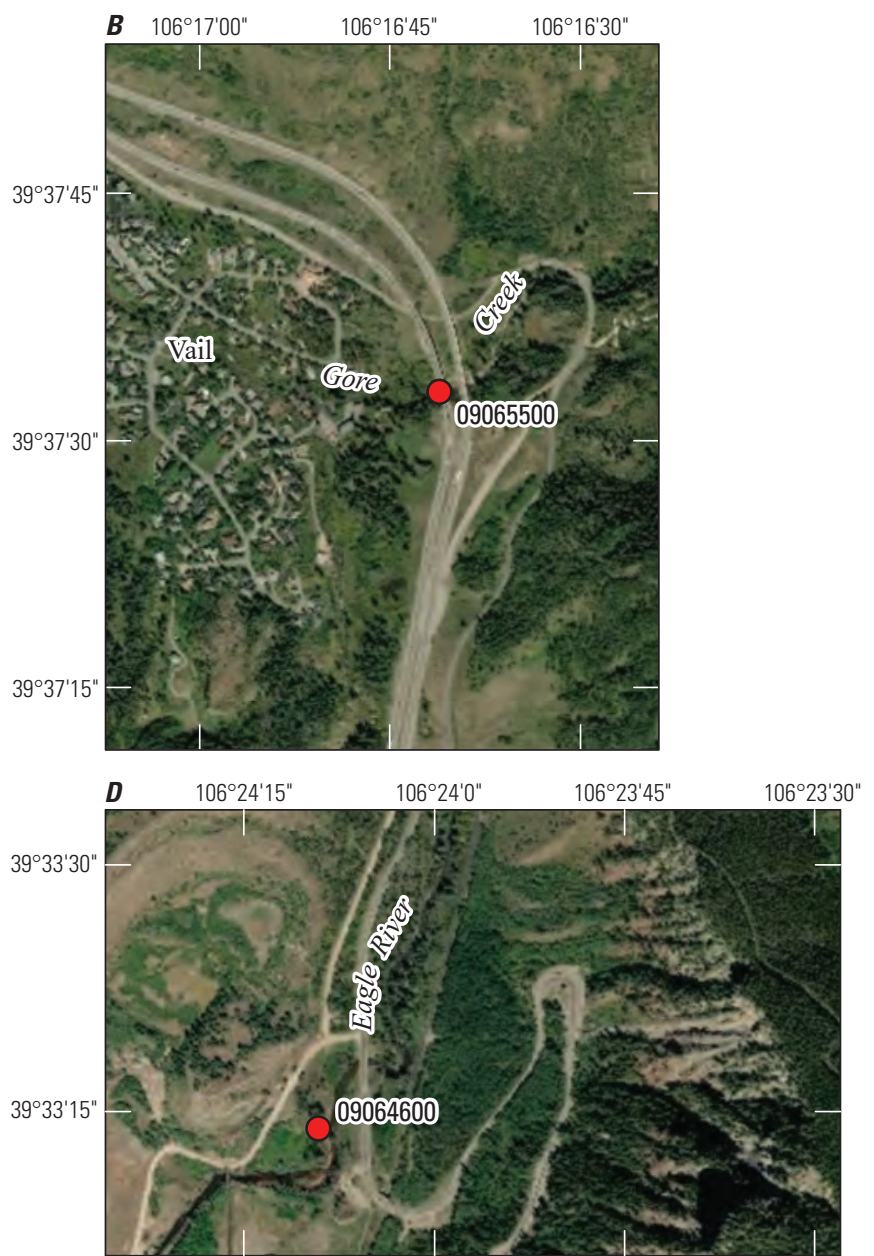
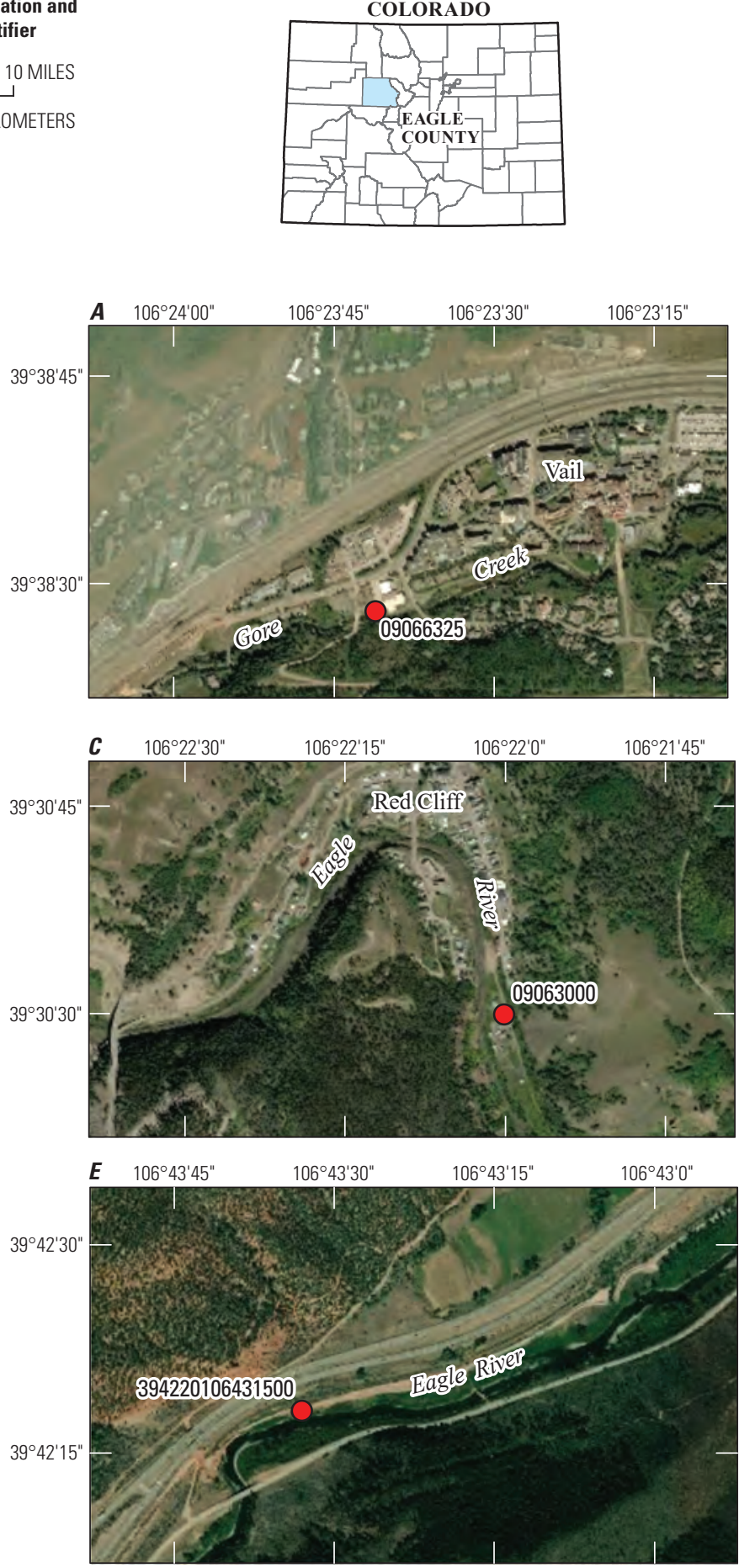

Map images is the intellectual property of Esri and is used herein under license. Copyright $(2019$ Esri and its licensors. All rights reserved,1:24,000 North American Datum of 1983

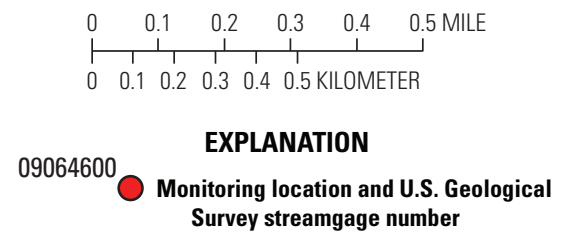

Survey streamgage number

Figure 1. Location of five water-quality sampling sites along the Eagle River and Gore Creek used to assess diel cycling, Eagle County, Colorado. 
USGS streamgage 09064600, Eagle River near Minturn, Colorado, is located along the main stem of the Eagle River within the Eagle Mine Superfund (fig. 1). Mining activities began in the mid-to-late-1800s, with the discovery of gold and silver in the region. By the late-1800s, zinc was the dominate ore being mined at the Eagle Mine, and it operated as one of the largest zinc mines in the United States (Colorado Department of Public Health and Environment and U.S. Environmental Protection Agency, 2008). Operation of the mine began to wind down in the early 1980s, and the mine began producing more copper and silver during this time. Production at the Eagle Mine ended in 1984, and it was designated as a superfund site in 1986 (Colorado Department of Public Health and Environment and U.S. Environmental Protection Agency, 2008). The majority of major remediation was completed in 1996, and recently postremediation operation and maintenance were amended to improve the quality of water entering the Eagle River, focusing on cadmium, copper, zinc, and arsenic (Colorado Department of Public Health and Environment and U.S. Environmental Protection Agency, 2018). This site was designated as a mine-affected location and potential for diel signals in trace elements exists. The lack of upstream nutrient inputs and historical samples with low nutrient concentrations reduces the likelihood of detecting a diel signal in nutrient concentrations (U.S. Geological Survey, 2019c).

USGS streamgage 09066325, Gore Creek above Red Sandstone Creek at Vail, Colorado, is located along the Gore Creek in Vail. Located near the downstream end of Vail, the site drains a large area of urban development, including the ski area, golf course, and numerous housing developments (fig. 1). This site location was a good candidate for an urban site, because there are few other inputs upstream to affect the potential diel signal.

USGS streamgage 394220106431500, Eagle River below Milk Creek near Wolcott, Colorado, drains the majority of the Eagle River Basin. Multiple urban areas, historical mining, and some agricultural land use allow this site to integrate the range of the land uses in the basin and assess how multiple factors combine to affect the diel signal in the Eagle River as a whole. These land uses allow the potential for a strong diel signal in nutrients that may not be present at the other sites and potentially in trace elements.

\section{Mechanisms of Diel Cycling}

Diel variations result from numerous processes. These processes can be physical, chemical, or biological, and in most systems, a combination of multiple processes is responsible for creating diel cycles (Nimick and others, 2011). The processes most applicable to the stream conditions in the Eagle River are discussed.

\section{Photosynthesis}

Oxygen and carbon dioxide concentrations can exhibit substantial diel cycles. These gases are important in controlling the variables affecting water geochemistry, including $\mathrm{pH}$ and reduction-oxidation states. Diel changes in $\mathrm{pH}$ are mainly due to the photosynthesis and respiration by aquatic plants and animals. As carbon dioxide is consumed and oxygen is released during the process of photosynthesis, $\mathrm{pH}$ increases throughout the day. Respiration overtakes photosynthesis during the nighttime period, consuming oxygen and releasing carbon dioxide, decreasing $\mathrm{pH}$. The temperature solubility of the gases can produce a diel cycle in concentrations, with higher concentrations at night when the temperatures are lower. However, the diel cycles of both oxygen and carbon dioxide are commonly dominated by photosynthesis and respiration by aquatic plants, algae, and other microbes (Odum, 1956). Photosynthesis and respiration both undergo diel cycles with photosynthesis exceeding respiration during the day, producing oxygen and consuming carbon dioxide; respiration consumes oxygen and produces carbon dioxide at night when photosynthesis stops (Forget and others, 2009).

Although these gases typically maintain an inverse relation throughout the diel cycle in streams, the production and consumption of the gases due to biological processes overwhelms the temperature solubility in the water. These biological processes lead to increasing and higher concentrations of dissolved oxygen during the day as a result of photosynthesis, even though dissolved oxygen solubility is decreasing as temperature increases (Loperfido and others, 2009). Similarly, carbon dioxide concentrations can decrease during the day as a result of photosynthesis, especially in highly productive streams and during productive portions of the year (Raymond and others, 1997; Guasch and others 1998; Dawson and others, 2001). Other processes besides photosynthesis, respiration, and temperature-dependent gas solubility affecting dissolved oxygen and carbon dioxide concentrations include kinetics of gas exchange with the atmosphere, temperature dependence of primary production, mixing, photolysis, and redox reactions (Loperfido and others, 2009). Although dissolved oxygen has little effect on stream geochemistry, it is documented by Harris and Smith (2009) in highly productive streams the consumption of dissolved oxygen by microbes during the night can create anoxic conditions. A study by Harrison and others (2005) documented diel changes in a wastewater dominated system ranging from more than 300 percent saturated to anoxic in only a few hours and resulted in the subsequent diel changes in redox-sensitive solutes including nitrate, nitrite, nitrogen, manganese, and iron following the conventional redox ladder presented in Stumm and Morgan (1996).

\section{Nutrients}

The concentrations of many nutrients, predominately in nitrogen species, have a diel cycle. The assimilation of nitrate by primary producers is thought to be the main cause of diel 
cycling, and the magnitude is dependent on numerous variables, including, light conditions, temperature, and autotrophic and heterotrophic activities (Hessen and others, 1997; Kent and others, 2005; Mulholland and others, 2006). However, in stream reaches downstream from wastewater discharge, the diel cycle of nutrient concentrations is dominated by nitrification (ammonia oxidation) and denitrification (nitrate reduction). The rate of nitrification is greater when water temperature, dissolved oxygen, and $\mathrm{pH}$ are higher (Warwick, 1986). During this process, nitrate and nitrite concentrations increase throughout the day, resulting in a decrease of ammonia (Johnson and others, 2002; Harrison and others, 2005; Harris and Smith, 2009; Smith and others, 2009; Gammons and others, 2011). In less productive and pristine streams, ammonia concentrations do not exhibit the same diel cycles (Roberts and Mulholland, 2007; Johnson and Tank, 2009). Nitrate and nitrite are also consumed during denitrification processes where they are reduced by specialized bacteria and release nitrogen gas as a byproduct. The processes of nitrification and denitrification are continually occurring throughout the day if oxygen and hydrogen are available for the processes.

\section{Variable Sources and Streamflow Cycles}

Diel patterns in water chemistry can be associated with changes in streamflow patterns during the day. Changes in streamflow patterns can be a result of numerous mechanisms but are typically a result of groundwater/surface water interaction, human inputs, or seasonal changes in streamflow patterns. Streams gaining or losing water to groundwater interaction, human inputs, or seasonal changes can display diel patterns because of dilution or concentration of the dissolved constituents in the water column. Diel patterns in streamflow for the western United States are typically a result of either changing rates in melting snowpack or consumption by vegetation (evapotranspiration) (Lundquist and Cayan, 2002). The variation in streamflow during the melting snowpack is documented, and the timing of the peaks and troughs are known to shift as the snowpack begins to thin (Grover and Harrison, 1966). The amplitude of the associated snowmelt peak, especially in high elevation streams, can be as much as 25 percent of the average daily streamflow (Lundquist and Cayan, 2002). Stream loses to evaporation and consumption by vegetation also create daily fluctuations in streamflow.

\section{Adsorption}

Adsorption has been documented as an important process affecting trace elements in neutral and alkaline systems. Adsorption reactions are temperature and $\mathrm{pH}$ controlled (Fuller and Davis, 1989; Nimick and others, 2003, 2011; Gammons and others, 2015). Adsorption reactions are documented to explain the diel cycle patterns of both cations and anions, which tend to exhibit opposite cycles. The reactions are also known to be fast and easily reversible allowing responses to continual instream changes throughout the day (Fuller and others, 1993; Fowle and Fein, 2000; Trivedi and Axe, 2000).

Numerous studies demonstrated the dependence of adsorption of ions onto metal oxide surfaces as temperature dependent (Machesky, 1990; Angove, and others, 1998; Trivedi and Axe, 2000; Scheckel and Sparks, 2001). Adsorption of cations is an endothermic reaction and increases with increasing temperature. The adsorption of anions, however, is an exothermic reaction and increases with decreasing temperature (Nimick and others, 2003, 2011). Based on reported enthalpy values in Machesky (1990) and Trivedi and Axe $(2000,2001)$, the theoretical adsorption enthalpy order would be zinc $\left(\mathrm{Zn}^{2+}\right)$ greater than $(>)$ cadmium $\left(\mathrm{Cd}^{2+}\right)>$ manganese $\left(\mathrm{Mn}^{2+}\right)>$ copper $\left(\mathrm{Cu}^{2+}\right)$, and the magnitude of the concentration change during the diel cycle would be highest in $\mathrm{Zn}$ and lowest in $\mathrm{Cu}$. Although temperature is documented as playing a role in the adsorption of cations and anions, it is less likely and typically not as important as $\mathrm{pH}$ for controlling diel cycles in metals (Nimick and others, 2003).

The importance of $\mathrm{pH}$ on adsorption reactions has been known for some time; increases in $\mathrm{pH}$ increase cation adsorption and reduce anion adsorption (Benjamin and Leckie, 1981; Dzomback and Morel, 1990). The reasoning behind the dependence on $\mathrm{pH}$ for adsorption reactions is largely due to protonation of hydrous metal oxide surfaces. As $\mathrm{pH}$ decreases, surfaces become more protonated, resulting in a positive charge, and therefore attracting negatively charged particles (anions) in the water column. The opposite is also true; as $\mathrm{pH}$ increases, surfaces become less protonated, resulting in a negative charge, attracting more positively charged particles (cations) in the water column (Dzomback and Morel, 1990; Nimick and others, 2003; Gammons and others, 2015). A similar reaction involving protonation and deprotonation is also documented to occur on the surfaces of organic matter, including bacteria and algal cells. These surfaces, known as biofilms, are another important substrate involved in adsorption in many streams (Fein and others, 2001). Stumm and Morgan (1996) illustrated the sensitivity of aqueous metal concentrations as the $\mathrm{pH}$ is near the adsorption boundaries of a solute. In a controlled, experimental environment, each metal ion has a narrow band of $\mathrm{pH}$ where the extent of adsorption changes from 0 to 100 percent.

\section{Importance of Iron and Manganese Reactions}

The diel variation of iron was first documented by McKnight and others in the late 1980s and has since been studied to a great extent, mostly in acidic streams (McKnight and Bencala, 1988; McKnight and others, 1988). There have been numerous processes documented affecting the diel variability of iron in streams. These include photoreduction, oxidation, precipitation of hydrous ferric oxides, transport of colloidal iron, and adsorption and desorption (Nimick and others, 2011). 
Photoreduction of dissolved and (or) colloidal iron from ferric iron $\left(\mathrm{Fe}^{3+}\right)$ to ferrous iron $\left(\mathrm{Fe}^{2+}\right)$ takes place at all $\mathrm{pH}$ values, but the reaction occurs quicker in a $\mathrm{pH}$ range of 2 to 4 (Collienne, 1983; McKnight and others, 2001). The oxidation of $\mathrm{Fe}^{2+}$ to $\mathrm{Fe}^{+3}$ appears to be strongly $\mathrm{pH}$ dependent and has been documented as being 6 orders of magnitude slower at $\mathrm{pH} 3$ compared to $\mathrm{pH} 7$ (Stumm and Morgan, 1996). These reactions are also sensitive to temperature and occur faster in warmer water conditions. Because there is a strong $\mathrm{pH}$ dependence on the rates of photoreduction and oxidation states, these mechanisms are not expected to create strong diel fluctuations in streams with neutral to alkaline $\mathrm{pH}$ values (McKnight and others, 2001). However, iron concentrations in neutral and alkaline steams can show variability and may increase during the night because of desorption of iron from hydrous ferric oxides as temperatures decrease or $\mathrm{pH}$ decreases and decreases in iron oxidation rates during the night (Wieder, 1994; Bäckström and others, 2002; Gammons and others, 2005; Parker and others, 2008; Borman and others, 2010; Gammons and others, 2010). Even though photoreduction and oxidation do not create strong diel variation in iron within neutral to alkaline streams, they help create high specific-surface-area hydrous ferric oxides, which are active surfaces for adsorption (Shiller and others, 2006).

Reactions involving the oxidation and reduction of $\mathrm{Mn}$ are documented as potential mechanisms for diel cycling of $\mathrm{Mn}$ as well as other trace elements (Scott and others, 2002; Fuller and Harvey, 2000). Oxidation of dissolved Mn leads to the precipitation of Mn oxide, potentially creating additional sorption sites enhancing the removal of other trace elements (Balistrieri and Murray, 1986; Catts and Langmuir, 1986). The Mn oxidation rate increases with increased $\mathrm{pH}$ and solar radiation promoting $\mathrm{Mn}$ oxide precipitation during the day. However, as $\mathrm{pH}$ decreases, and solar radiation decreases, the Mn oxides becomes reduced and dissolve, releasing Mn back into the water column (Stumm and Morgan, 1996; Scott and others, 2002). The oxidation and reduction of Mn oxide potentially play an important role explaining the diel cycles of $\mathrm{Mn}$ and other associated trace elements.

\section{Methods}

The determination of diel cycles in the Eagle River Basin was approached using multiple methodologies during late-summer and early-fall river conditions. Multiparameter sondes at five sites were deployed in 2017 to evaluate the water-quality properties and determine if conditions were favorable for the diel cycling of trace elements and nutrients. Additionally, a detailed water-quality sampling, targeting nutrients and trace elements, was completed in 2018 at three of the five sites to confirm the presence or absence of diel cycling and, where present, the magnitude of the daily variation.

\section{Water-Quality Monitoring}

Water-quality properties were collected at five sites in the Eagle River Basin from late July through early October using water-quality monitors (table 1). Water temperature, specific conductance, dissolved oxygen, and $\mathrm{pH}$ were recorded at 15-minute intervals using a YSI 600XL water-quality sonde using the standard techniques and methods described in Wagner and others (2006). Water-quality sondes were deployed in perforated 2 in. schedule 40 polyvinyl chloride pipe and positioned near the streambed. An Apogee SQ520 full spectrum photosynthetically active radiation (PAR) sensor, recording every 15 minutes, was deployed near each monitor location, typically as near to the streamgage shelter as possible, with as few overhead obstructions as possible to maximize solar radiation reaching the sensor. Water-quality properties and PAR data are available in the USGS National Water Information System (NWIS) database (U.S. Geological Survey, 2019a).

\section{Water-Quality Data Collection}

Based on the 2017 water-quality monitoring data, sites were selected where water-quality properties indicated the potential for measurable diel cycles: 09066325 Gore Creek above Red Sandstone Creek at Vail, 09064600 Eagle River near Minturn, and 394220106431500 Eagle River below Milk Creek near Wolcott. In 2018, water-quality samples were collected in early September. This timing was selected to minimize streamflow effects on diel cycling relative to biogeochemical effects. Historical hydrographs indicated stable base-flow conditions should be present during this time period, allowing for a quantification of diel cycling without interference from streamflow variability (U.S. Geological Survey, 2019a). A YSI EXO1 water-quality sonde was also deployed during the sampling period measuring water temperature, specific conductance, dissolved oxygen, and $\mathrm{pH}$ at 15-minute intervals using the standard techniques and methods described in Wagner and others (2006). The Apogee SQ520 PAR sensors were not deployed during the 2018 sampling; therefore, a modeled PAR was used to quantify solar radiation instead. Modeled PAR values were calculated using the Clear Sky Calculator and the latitude and longitude of the Eagle, Colo., airport as a reference location (Apogee Instruments, 2019).

Samples at sites 09064600 and 394220106431500 were collected during a 24-hour period, about every 4 to 5 hours, resulting in 8 samples, including associated quality assurance and quality control (QA/QC) samples (1 split replicate) at each site. Site 09066325 had 2 samples collected during a 24-hour period, targeting the times of day having the highest potential for maximum and minimum results, allowing for a quantification of magnitude. Samples at 4- to 5-hour intervals were not collected at this site based on a previous evaluation of the 2017 monitor data. Inconsistencies and anomalies in the monitor data in 2017 led to uncertainty whether conditions at 
this site would allow for diel cycling to be present, and if so, it was caused by an unknown input source. For these reasons, it was determined that sampling to target the potential maximum and minimum would allow for an informative determination of diel cycling.

Water-quality samples were collected following protocols and procedures in the "National Field Manual for the Collection of Water-Quality Data" (U.S. Geological Survey, variously dated). Water-quality samples were collected using the equal-width-increment method and a United States standard sampler, Depth integrating, Hand-held developed in 1981 (US DH-81) attached to a United States standard sampler, Depth integrating developed in 1995 (US D-95) tetrafluoroethylene cap and nozzle with a 1-liter fluorinated ethylene propylene bottle and composited in an 8-liter polyethylene churn splitter. Raw water samples were drawn directly from the churn splitter, whereas filtered samples were filtered with a 0.45 -micrometer $(\mu \mathrm{m})$ filter. Nitric acid was used to preserve samples for cation and trace-element analysis, and sulfuric acid was used for preservation of samples for nutrient analysis as described in U.S. Geological Survey (2002). All samples were collected wearing powderless surgical gloves to prevent contamination during the collection and handling.

Laboratory analysis was conducted at the USGS National Water Quality Lab in Lakewood, Colo., following standard techniques and methods described by Fishman and Friedman (1989); Hoffman and others (1996); Garbarino and others (2005); Patton and Kryskall (2011); Fishman (1993); Patton and Truitt (2000); and U.S. Geological Survey (2010).

Samples were analyzed for low-level nutrients (including ammonia, nitrate, nitrite, orthophosphate, and phosphorus), trace elements and dissolved organic carbon. Quality assurance and quality control was conducted during the sampling period. Two QA/QC samples were collected, consisting of two replicate samples, approximately 10 percent of the collected samples during the sampling period. The QA/QC samples were analyzed at the National Water Quality Laboratory in Lakewood, Colo., using methods described in Pritt and Raese (1992). Water-quality sample data are available from the USGS NWIS database (U.S. Geological Survey, 2019a).

\section{Evaluation of 2017 Water-Quality Monitor Data}

The YSI 600XL water-quality sonde data were evaluated at each site after an approximately 2-month deployment in the late summer and early fall 2017. Assessment of the waterquality properties (water temperature, dissolved oxygen, $\mathrm{pH}$, specific conductance, and streamflow) and PAR allowed for an interpretation of the potential for diel cycles at each site. Although each site was fundamentally different regarding source water and nearby human processes, the overall patterns in water parameters were similar between sites (fig. 2). Streamflow gradually decreased during the deployment, and specific conductance increased at each site. Water temperature remained consistent through much of the deployment before decreasing in early September. Dissolved oxygen and $\mathrm{pH}$ also remained consistent through the deployment, with no substantial increases or decreases. Missing data in the graphs are a result of removing data determined to be erroneous.

\section{Streamflow}

Streamflow patterns were typical of mountain stream systems. Streamflow decreased through the deployment at most of the sites until late August or early September when base-flow conditions were reached. The typical daily streamflow pattern at most sites was an increase through the morning period, with a maximum near the middle of the day and then decreasing through the afternoon and evening until the middle of the night. Sites higher up in the basin had little variability, and a daily pattern in streamflow was not as noticeable (figs. $2 A$ and $D$ ). Numerous short-term increases in streamflow throughout the deployment are attributed to late-summer precipitation in the area. Streamflow increased from upstream to downstream, with the lowest streamflow at site 09065500 and the highest streamflow at site 3942201064315000 (fig. 2). Streamflow ranged from 3.9 to 33.0 (averaging 6.5) cubic feet per second $\left(\mathrm{ft}^{3} / \mathrm{s}\right.$ ) at site 09065500 and from 95.6 to 552 (averaging 151 ) $\mathrm{ft}^{3} / \mathrm{s}$ at site 394220106431500 (figs. $2 A$ and $F$ ). The remaining sites varied in streamflow depending on location and inputs upstream from the site. Site 09066325 ranged from 18.0 to $113 \mathrm{ft}^{3} / \mathrm{s}$, averaging $29.4 \mathrm{ft}^{3} / \mathrm{s}$ (fig. $2 B$ ). The upstream Eagle River sites 09063000 and 09064600 ranged from 11.7 to 69.9 (averaging 17.5) $\mathrm{ft}^{3} / \mathrm{s}$ and from 40.9 to 210 (averaging $51.7) \mathrm{ft}^{3} / \mathrm{s}$, respectively (figs. $2 D$ and $E$ ). The increase in flow between the sites is attributed to Homestake Creek joining the Eagle River upstream from 09064600 (fig. 1). Streamflow at site 394220106431500 (fig. $2 F$ ) averaged about $70 \mathrm{ft}^{3} / \mathrm{s}$ more than sites 09064600 and 09066325 combined.

\section{Water Temperature}

Water temperature remained consistent through August. Sites at higher elevation and shaded in valleys (sites 09065500, 09066325, and 09063000) had cooler temperatures during the deployment with the average water

Figure 2 (following page). 2017 variation in water temperature, $\mathrm{pH}$, streamflow, specific conductance, dissolved oxygen, photosynthetically active radiation, and daily average photosynthetically active radiation at site $A, 09065500$ (Gore Creek at Upper Station, near Minturn, Colorado [CO]), B, 09066325 (Gore Creek above Red Sandstone Creek, C0), C, zoomed in specific conductance and streamflow at site 09066325 (Gore Creek above Red Sandstone Creek, CO), D, 09063000 (Eagle River at Red Cliff, CO), E, 09064600 (Eagle River near Minturn, CO), and $F$, 394220106431500 (Eagle River below Milk Creek near Wolcott, CO). 

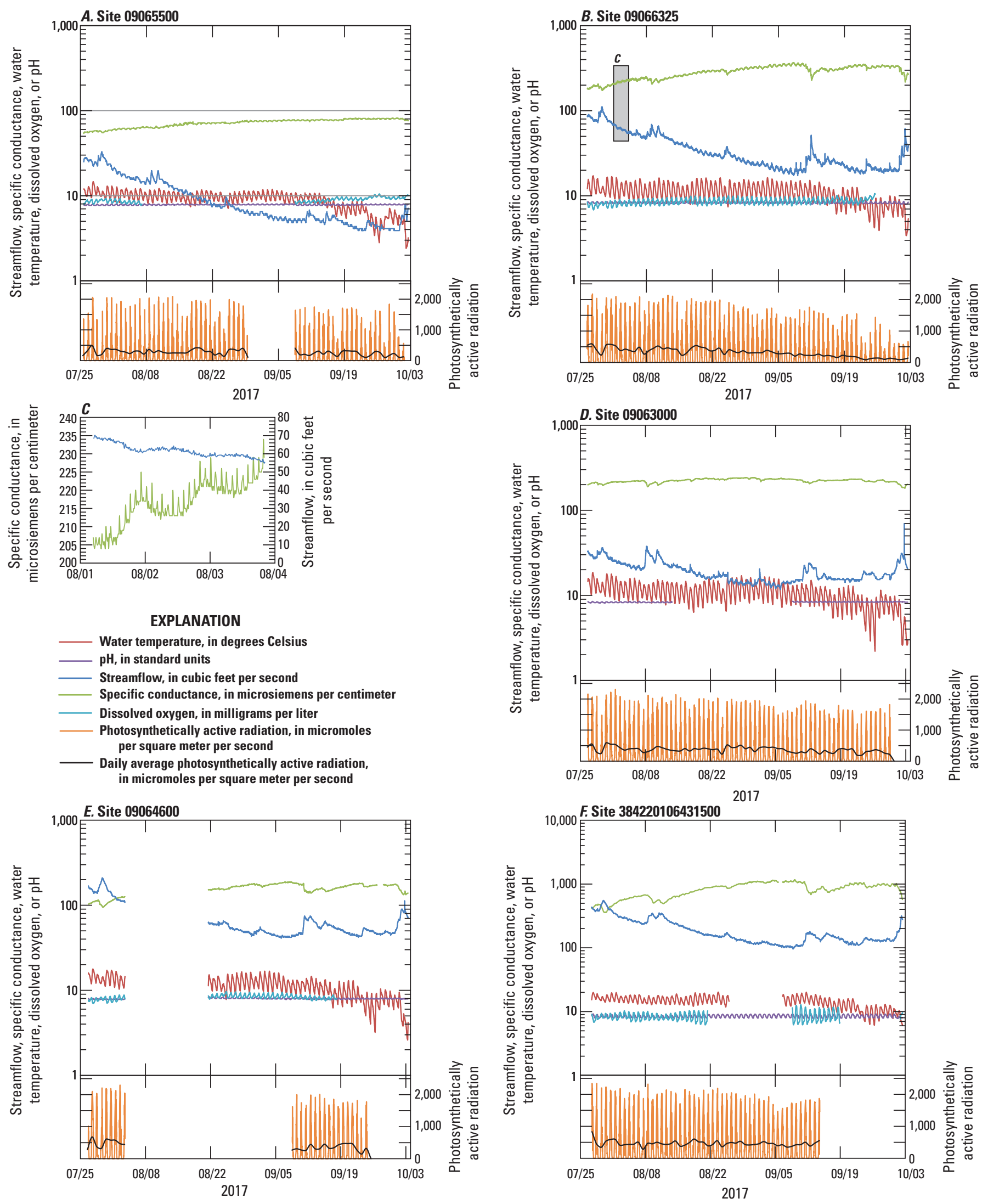
temperatures near 10.0 degrees Celsius $\left({ }^{\circ} \mathrm{C}\right)$ (table 2).

Site 394220106431500 had the warmest median temperature of $14.6^{\circ} \mathrm{C}$ and was the only site to record a water temperature warmer than $20.0^{\circ} \mathrm{C}$ (table 2 ). Water temperatures gradually decreased through September and decreased rapidly at the beginning of October (fig. 2).

\section{Specific Conductance}

Specific conductance maintained an inverse relation with streamflow at the deployment sites. This relation is more visible at sites with higher specific conductance values but is present at all sites. All sites showed slight increases in specific conductance through the deployment, mirroring the decrease in the streamflow as it nears base-flow conditions (fig. 2).

Sites 09065500 and 09063000 had lower values and a smaller increase through the deployment. The maximum and minimum values were dictated by the variability in the streamflow at these sites, and there was no visible pattern to the interdaily change in specific conductance (fig. 2). Values ranged from 54.0 to 82.0 microsiemens per centimeter $(\mu \mathrm{S} / \mathrm{cm})$ and 181 to $243 \mu \mathrm{S} / \mathrm{cm}$, respectively (table 2 ). Specific conductance values for site 09064600 ranged from 95.0 to $188 \mu \mathrm{S} / \mathrm{cm}$ (median $165)$ during the deployment, with the minimum occurring during high flow in late July and the maximum occurring during low flow in late August and early September (fig. 2E).

Table 2. Summary of 2017 water-quality monitoring deployments at five sites in the Eagle River Basin, Eagle County, Colorado.

$\left[\mathrm{CO}\right.$, Colorado; ${ }^{\circ} \mathrm{C}$, degrees Celsius; $\mu \mathrm{S} / \mathrm{cm}$, microseimens per centimeter; $\mathrm{mg} / \mathrm{L}$, milligrams per liter; —, no data $]$

\begin{tabular}{|c|c|c|c|c|c|}
\hline Parameter & Minimum & $\begin{array}{l}\text { Time of minimum }{ }^{1} \\
\text { (24 hour) }\end{array}$ & Median & Maximum & $\begin{array}{c}\text { Time of maximum } \\
\text { (24 hour) }\end{array}$ \\
\hline \multicolumn{6}{|c|}{09065500 Gore Creek at Upper Station, near Minturn, CO } \\
\hline Specific conductance, in $\mu \mathrm{S} / \mathrm{cm}$ & 54.0 & 1700 & 74.0 & 82.0 & ${ }^{1} 0545$ \\
\hline Dissolved oxygen, in mg/L & 7.7 & 12000 & 8.9 & 10.5 & ${ }^{1} 0945$ \\
\hline \multicolumn{6}{|c|}{09066325 Gore Creek above Red Sandstone Creek at Vail, CO } \\
\hline Water temperature, in ${ }^{\circ} \mathrm{C}$ & 3.4 & ${ }^{1} 0245$ & 10.7 & 17.2 & ${ }^{1} 1715$ \\
\hline Specific conductance, $\mu \mathrm{S} / \mathrm{cm}$ & 173 & 1515 & 297 & 369 & 0245 \\
\hline Dissolved oxygen, mg/L & 6.8 & 1900 & 8.5 & 10.6 & ${ }^{1} 1015$ \\
\hline Specific conductance, $\mu \mathrm{S} / \mathrm{cm}$ & 181 & ${ }^{1} 1915$ & 224 & 243 & ${ }^{1} 1345$ \\
\hline Dissolved oxygen $^{2}$, in $\mathrm{mg} / \mathrm{L}$ & - & - & - & - & - \\
\hline $\mathrm{pH}$, in standard units & 8.1 & ${ }^{1} 0445$ & 8.3 & 8.5 & ${ }^{1} 1445$ \\
\hline \multicolumn{6}{|c|}{09064600 Eagle River near Minturn, CO } \\
\hline Water temperature, in ${ }^{\circ} \mathrm{C}$ & 2.6 & ${ }^{1} 0900$ & 11.0 & 17.8 & 1645 \\
\hline Specific conductance, in $\mu \mathrm{S} / \mathrm{cm}$ & 95.0 & ${ }^{1} 1915$ & 165 & 188 & 12200 \\
\hline Dissolved oxygen, in mg/L & 7.0 & ${ }^{1} 1945$ & 8.3 & 9.7 & ${ }^{1} 0945$ \\
\hline $\mathrm{pH}$, in standard units & 7.8 & ${ }^{1} 0745$ & 8.0 & 8.4 & ${ }^{1} 1615$ \\
\hline \multicolumn{6}{|c|}{394220106431500 Eagle River below Milk Creek near Wolcott, CO } \\
\hline
\end{tabular}

${ }^{1}$ When minimum or maximum values occur at multiple times during the deployment, the reported time is the average of all times with the minimum or maximum value.

${ }^{2}$ Data were determined to be erroneous and unusable. The magnitude of the daily cycles and highly erratic nature of the data indicated there was an internal problem with the sensor. Data were not correctable or usable for data analysis. 
Site 09066325 had the same pattern throughout the deployment, ranging from 173 to 369 (median 297) $\mu \mathrm{S} / \mathrm{cm}$ (table 2). The minimum and maximum values were similar in timing to site 09064600 and were associated with maximum and minimum streamflow values during the deployment (fig. $2 B$ ). Although the overall trend in the specific conductance at site 09066325 was typical of a natural stream system, maintaining an inverse relation with streamflow, there were some short-term inconsistencies that could not be explained. There were many rises and drops during the day, some associated with small decreases or increases with streamflow, and some with no change in flow (fig. 2C). This pattern indicated there was potentially an unknown streamflow input upstream from the site potentially affecting the water chemistry.

As with many of the other parameters, site 394220106431500 had a wider range of specific conductance values than the other deployment sites and ranged from 358 to $1,170 \mu \mathrm{S} / \mathrm{cm}$ (median 872) throughout the deployment (table 2). Like the other sites, minimum and maximum specific conductance values occurred during the maximum and minimum streamflow conditions, respectively, for the deployment (fig. 2F).

\section{Dissolved Oxygen}

Dissolved oxygen concentrations had a consistent diel cycle from day to day inverse to the cycle of water temperature in most cases (greater during cool nighttime temperatures, less during warm daytime temperatures). Most of the sites had concentrations ranging from 6.8 to 10.6 milligrams per liter $(\mathrm{mg} / \mathrm{L})$, with a median dissolved oxygen concentration from 8.0 to $9.0 \mathrm{mg} / \mathrm{L}$ (table 2). Sites with a median concentration close to $9.0 \mathrm{mg} / \mathrm{L}$ also had a lower median water temperature. The exception was site 394220106431500 where dissolved oxygen was more variable through the deployment (fig. 2). The larger magnitude of diel change in dissolved oxygen at site 394220106431500 coincided with times of higher water temperature (fig. 2), indicating that biological activity, in the form of algal growth, was potentially enhancing the production and consumption of dissolved oxygen during the deployment. During many days, dissolved oxygen appears to exceed the theoretical percentage saturation capacity of the water (U.S. Geological Survey, variously dated), also an indication that dissolved oxygen is being produced at a high rate during times of deployment. The maximum dissolved oxygen $(12.7 \mathrm{mg} / \mathrm{L})$ and the minimum dissolved oxygen $(6.2 \mathrm{mg} / \mathrm{L})$ concentrations occurred on September 10, 2017 (table 2, fig. 2), indicating dissolved oxygen production from photosynthesis and consumption from respiration was supplementing the background gas exchange normally taking place throughout the day. Site 09063000 had no usable dissolved oxygen data because of a sensor malfunction that was not able to be corrected during the deployment (table 2).
pH

Diel changes in $\mathrm{pH}$ were consistent at each site throughout the deployment. The magnitude of diel change remaining similar from day to day, with the maximum value in the early afternoon and the minimum value occurring in the early morning (table 2). The general shape of the daily pattern mirrored water temperature; however, the minimum $\mathrm{pH}$ occurred much earlier in the morning than the minimum temperature at most sites (table 2). Smaller diel changes in $\mathrm{pH}$ occurred at the sites with less biological activity and cooler water conditions. Sites 09065500 and 09063000 had the smallest diel cycling of $\mathrm{pH}$ ranging from 7.7 to 8.0 standard units (median of 7.8) and from 8.1 to 8.5 standard units (median of 8.3), respectively (table 2). The magnitude of the diel change at site 09066325 ranged from 7.9 to 8.6 standard units. Values less than 8.1 standard units occurred on a few days in late September and early October (fig. 2). Site 09064600 had minimum $\mathrm{pH}$ value of 7.8 standard units and a maximum $\mathrm{pH}$ value of 8.4 standard units (median 8.0) during the deployment (table 2). Values less than 7.9 standard units occurred early in the monitoring period, during warmer water temperatures (fig. 2). Although most of the deployment sites were similar in $\mathrm{pH}$ range and diel magnitude, the $\mathrm{pH}$ values at site 394220106431500 behaved differently (fig. 2). The $\mathrm{pH}$ ranged from 7.8 to 9.2 standard units (median 8.5) during the deployment (table 2). The difference from minimum to maximum value was 3 to 5 times greater than the other deployment sites (table 2). The diel cycle of $\mathrm{pH}$ values consistently ranged from 8.0 to 9.0 standard units on most days, with the extreme values occurring on days with warmer water temperatures and larger ranges in dissolved oxygen (fig. 2). The higher $\mathrm{pH}$ values at this site indicate carbon dioxide consumption because of increased algal growth, reinforcing the photosynthesis and respiration cycle play an important role in controlling the diel $\mathrm{pH}$ cycle.

\section{Photosynthetically Active Radiation}

Photosynthetically active radiation is an important input to the photosynthesis and respiration cycle and closely ties it to the diel cycles of $\mathrm{pH}$ and dissolved oxygen. The PAR represents the amount of radiation in the wavelength of light used by plants for photosynthesis, and it controls the amount of photosynthesis occurring in a day. A full range of PAR values from 0.0 to about 2,300 micromoles per square meter per second $\left(\mu \mathrm{mol} / \mathrm{m}^{2} / \mathrm{s}\right)$ occurred at the deployment sites (fig. 2 ). Each site has slightly different PAR values because of shading from mountains, trees, localized cloud cover, and orientation of the sun relative to the sensor. The temporal distribution of PAR values at the sites was consistent; however, higher values occurred earlier in the deployment period and slowly decreased toward the end of the deployment because of migration of the sun to a lower latitude relative to its summer position, which decreased the radiation reaching the sensor (fig. 2). 


\section{Overview of 2017 Diel Patterns}

Overall, the diel patterns observed in the 2017 waterquality monitoring were consistent for each parameter from site to site, with more variability occurring at sites with more aquatic productivity. The headwater sites, 09065500 , 09063000, and 09064600, had similar results across all parameters monitored (water temperature, specific conductance, dissolved oxygen, and $\mathrm{pH}$ ) and showed little variability throughout the deployment in many parameters (fig. 2). The remaining sites 09066325 and 394220106431500 had more variability in some parameters, specifically, $\mathrm{pH}$ and dissolved oxygen (fig. 2).

Streamflow throughout the basin had an overall consistent pattern between all the sites. Decreases in streamflow during the deployment were seen at all sites (fig. 2). Sites 09065500, 394220106431500 , and 09064600 did not exhibit much diel variation in streamflow through the period. Sites 09066325 and 4220106431500 exhibited a more discernable diel cycle in streamflow with the maximum values typically in the middle of the day and the minimum around midnight (fig. 2).

Water temperature typically increased from upstream to downstream in the basin, with the warmest temperatures occurring in the late summer and gradually decreasing throughout the deployment (fig. 2). Water temperature exhibited a diel variation at all sites with the maximum values occurring in the late afternoon and then decreasing to a minimum value just before sunrise for most sites (table 2). This same pattern was universal between all sites and is a result of the availability of solar radiation to warm the surrounding air and directly heat the water.

Specific conductance followed an inverse relation to streamflow, generally increasing at most sites as streamflow was decreasing through the deployment. Sites with little daily variation in streamflow also had little variation in specific conductance (fig. 2). The sites where a diel pattern in streamflow existed, also had a diel pattern in specific conductance, inverse of the streamflow pattern.

Dissolved oxygen tended to follow an inverse relation to water temperature at most sites. Sites having little biological activity or little evidence of algae and aquatic plant growth had the maximum dissolved oxygen value occur at, or just after the minimum temperature. Sites with visible algal growth and aquatic productivity, primarily sites 09066325 and 394220106431500, had maximum dissolved oxygen concentrations near 1200, typically a few hours after the minimum water temperature. Minimum dissolved oxygen typically occurred just prior to sunset, also a few hours after the maximum water temperature. The sites with more aquatic productivity also exhibited the largest magnitude in diel cycle (table 2) and are also attributed to the increased photosynthetic and respiration activity in these reaches.

The diel pattern of $\mathrm{pH}$ was consistent through the deployment period at each site. The sites located in the headwaters have little variation in $\mathrm{pH}$ through the deployment as well as a small change in diel magnitude (fig. 2). The diel variation maintained an inverse relation to dissolved oxygen at the sites with little aquatic productivity. However, at sites with aquatic productivity $(09066325,394229106431500)$, the relation between $\mathrm{pH}$ and dissolved oxygen became out of phase slightly, but the maximum $\mathrm{pH}$ typically occurring late in the afternoon, presumably during the peak of the photosynthetic activity for the day (fig. 2, table 2). The minimum $\mathrm{pH}$ would then occur just prior to sunrise, corresponding not only to the lower water temperatures for the day, but also infers increased carbon dioxide values as a result of respiration occurring through the nighttime period. The sites demonstrating more variability and larger diel cycles in $\mathrm{pH}$ were of more interest to a detailed sampling. The sites tending to show the most $\mathrm{pH}$ variability included 09066325,09064600 , and 3942220106431500 , which may indicate these sites are more prone to the mechanisms driving diel cycling in nutrients and trace elements outlined in the Mechanisms of Diel Cycling section of this report.

\section{Assessment of Diel Cycling in Nutrient and Trace-Element Concentrations}

Nutrient and trace-element diel cycles were assessed at three sites in the Eagle River Basin (09064600, 09066325, and 394220103431500) and were selected based on the results of the 2017 water-quality monitoring deployments and an assessment of the historical water-quality information at all five sites. The assessment of the 2017 water-quality monitoring deployments was useful in determining sites having potential to allow for diel cycling in either trace elements or nutrients, based on patterns in streamflow, temperature, dissolved oxygen, and more importantly, $\mathrm{pH}$. Historical water-quality information was also assessed at each site to understand if historical samples indicated concentrations were at levels high enough to assess a diel cycle. Because of the high number of censored values for both trace-elements and nutrient concentrations, sites 09063000 and 09065500 were determined to be poor candidates for the diel cycling assessment. The diel cycle assessment included collecting water-quality samples during at least 24 hours in conjunction with short term, water-quality monitoring deployments.

\section{Water-Quality Data Collection}

Water-quality samples were collected every 4 to 5 hours at sites 09064600 on September 5 and 6 and 394220106431500 on September 10 and 11, and two samples were collected at site 09066325 on September 5 and 6 targeting the potential minimum and maximum values for the day at 1500 and 0400 hours (24-hour time) based on analysis of the 2017 monitoring data at the site. Two samples were collected at site 09066325 instead of a total of seven samples, because of the 2017 water-quality monitoring deployment data 
displayed some inconsistencies in both streamflow and specific conductance along with the lack of historical sample data. These inconsistencies included irregular spikes in streamflow and specific conductance creating concern there was a point-source input, which may mute or create a value that may indicate a diel was happening, when it was just a result of an inconsistent input. Also, because there was a lack of historical samples, it was determined expending limited resources on sampling this site every 4 to 5 hours was not a good use of the resources and allowed for more samples to be collected at the other sites. However, two samples were still collected at this site targeting the minimum and maximum values for the data, which allowed for a diel cycle to be detected, if present, and possibly indicate what the magnitude would be. Concurrent water-quality monitoring deployments at the time of sampling were used to verify the minimum and maximum $\mathrm{pH}$ value, which was targeted as the time of sampling. Water-quality properties and water-quality samples for nutrients and trace elements were collected at each site.

\section{Quality Assurance and Quality Control}

Quality assurance and quality control samples were collected equivalent to about 10 percent of total samples collected. The QA/QC consisted of two split-replicate samples, one sample each at sites 09064600 and 394220106431500 . Differences between replicate samples would indicate either variability in the analytical methodology or variability in field methods and equipment regarding the filtering and splitting of the sample prior to analysis. Numerous or large amounts of variation may identify a problem with field methods potentially adding bias or variability into the data prior to laboratory analysis. The relative percent difference was calculated to assess variability between the environmental and replicate samples (table 3). Mueller and others (2015) cautioned the high variability associated with relative percent differences greater than 20 percent could affect the interpretation of the environmental data.

Only two replicate pairs exceeded a relative percent difference of 20 percent. At site 09064600 , total phosphorus had a relative percent difference of 28.6 percent, and total arsenic had a relative percent difference of 28.6 percent at site 394220106431500 (table 3). Concern for the high relative percent differences affecting the interpretation of the environmental data is minor because of the generally low concentrations. In this case, small variations in concentrations between replicate pairs can give the impression of high relative percent differences, as seen in total phosphorus, where concentrations are 0.006 and $0.008 \mathrm{mg} / \mathrm{L}$ (table 3). A similar relation is between the replicate pairs associated with the high relative percent differences in total arsenic where concentrations are 0.3 and $0.4 \mu \mathrm{g} / \mathrm{L}$, giving the impression of a large relative percent difference, even though the difference in concentrations is small.

\section{Water-Quality Properties}

Water-quality properties, including temperature, specific conductance, dissolved oxygen, $\mathrm{pH}$, alkalinity, were measured with each sample collected. The corresponding streamflow from a stage-discharge relation at the corresponding USGS streamgage was documented for each sample, along with a modeled PAR value (table 4).

Streamflow was stable during sampling at all three sites, with the largest percentage diel change of 6.1 percent $\left(2.0 \mathrm{ft}^{3} / \mathrm{s}\right.$, with a median streamflow of $\left.35.0 \mathrm{ft}^{3} / \mathrm{s}\right)$ occurring at site 09064600 during the sampling period. Streamflow varied by 2.2 percent $\left(0.3 \mathrm{ft}^{3} / \mathrm{s}\right.$, with a median streamflow of $\left.13.6 \mathrm{ft}^{3} / \mathrm{s}\right)$ and 5.3 percent $\left(4.0 \mathrm{ft}^{3} / \mathrm{s}\right.$, with a median streamflow of $78.0 \mathrm{ft}^{3} / \mathrm{s}$ ) for sites 09066325 and 394220106431500 , respectively (table 4). Minimal variation with streamflow, along with minimal variation in specific conductance, indicated conditions during the sampling were steady, and the effect of streamflow on the diel cycle of nutrients and trace elements was negligible.

Water temperature varied between all sites and increased in value and magnitude farther downstream (fig. 1, table 4). Diel water-temperature cycle predictably showed maximum temperature during daytime occurring on September 6, 2018, at 1400 hours at site $09064600\left(12.6^{\circ} \mathrm{C}\right)$, on September 5, 2018 , at 1500 hours at site $09066325\left(12.5^{\circ} \mathrm{C}\right)$, and at September 10, 2018, at 1600 hours at site 394220106431500 $\left(19.3^{\circ} \mathrm{C}\right)$. At most sites, minimum temperatures occurred during night on September 6, 2018, 0500 hours at site 09064600 $\left(8.9^{\circ} \mathrm{C}\right)$, on September 6, 2018, at 0400 hours at site $09066325\left(9.0^{\circ} \mathrm{C}\right)$, and on September 11, 2018, at 0900 hours at site $394220106431500\left(11.9^{\circ} \mathrm{C}\right)$ (table 4$)$.

The diel cycle in $\mathrm{pH}$ varied between all three sites, with the largest variation occurring at site $394220106431500 \mathrm{pH}$ varied from 8.0 to 9.3, peaked on September 10, 2018, at 1600 hours and had minimum values on September 11, 2018, at 0500 hours) and the lowest variation at site $09064600(\mathrm{pH}$ varied from 7.8 to 8.2, peaked on September 5, 2018, at 1600 and September 6, 2018, at 1400 hours and had minimum values on September 5, 2018, at 1230 and on September 6, 2018, at 0100 hours). Site 09066325 was intermediate (pH varied from 8.1 to 8.6, peaked on September 5, 2018, at 1500 hours and had minimum values on September 6, 2018, at 0400 hours) (table 4 , fig. 3 ). The variation between sites indicates the processes and magnitude of the diel effect caused different $\mathrm{pH}$ behavior between each site. These processes causing diel variation in $\mathrm{pH}$ may include (1) carbon dioxide gas exchange (fig. 3) and (2) biological processes, specifically those related to photosynthesis and respiration, which occur even in systems having minor algae and aquatic plant growth.

Site 09064600 had visibly less algae and aquatic plant growth than the other sites and could be described as having limited algae or plant growth during the sampling period, and it was the only site to have a measured $\mathrm{pH}$ value below 8.0, consistent with having the highest measured carbon dioxide at all three sites of $2.8 \mathrm{mg} / \mathrm{L}$ (fig. 3). The diel cycle of $\mathrm{pH}$ at this 
[Blue box, highlights values of high variability; bold text, identifies relative percent differences greater than 20 percent. CO, Colorado; N, nitrogen; mg/L, milligrams per liter; $\mu \mathrm{g} / \mathrm{L}$, micrograms per liter; $<$, less than]

\begin{tabular}{|c|c|c|c|c|c|c|}
\hline \multirow{2}{*}{ Parameter } & \multicolumn{3}{|c|}{$\begin{array}{l}09064600 \\
\text { Eagle River near Minturn, CO }\end{array}$} & \multicolumn{3}{|c|}{$\begin{array}{c}394220106431500 \\
\text { Eagle River below Milk Creek near Wolcott, CO }\end{array}$} \\
\hline & Environmental & Replicate & $\begin{array}{c}\text { Relative percent } \\
\text { difference }^{1}\end{array}$ & Environmental & Replicate & $\begin{array}{c}\text { Relative percent } \\
\text { difference }^{1}\end{array}$ \\
\hline Ammonia, filtered as $\mathrm{N}(\mathrm{mg} / \mathrm{L})$ & $<0.01$ & $<0.01$ & 0 & 0.01 & $<0.01$ & 0 \\
\hline Ammonia + Organic $\mathrm{N}$, total recoverable as $\mathrm{N}(\mathrm{mg} / \mathrm{L})$ & 0.12 & 0.1 & 18.2 & 0.27 & 0.29 & 7.14 \\
\hline Nitrate + Nitrite, filtered as $\mathrm{N}(\mathrm{mg} / \mathrm{L})$ & $<0.10$ & $<0.10$ & 0 & 0.32 & 0.32 & 0 \\
\hline Nitrate, filtered as N (mg/L) & $<0.10$ & $<0.10$ & 0 & 0.32 & 0.31 & 0.95 \\
\hline Nitrite, filtered as $\mathrm{N}(\mathrm{mg} / \mathrm{L})$ & $<0.001$ & $<0.001$ & 0 & 0.008 & 0.009 & 11.8 \\
\hline Total nitrogen, total recoverable, $(\mathrm{mg} / \mathrm{L})$ & $<0.13$ & $<0.11$ & 0 & 0.6 & 0.61 & 1.65 \\
\hline Organic nitrogen, filtered $(\mathrm{mg} / \mathrm{L})$ & $<0.12$ & $<0.10$ & 0 & 0.26 & 0.29 & 10.9 \\
\hline Orthophosphate, filtered (mg/L) & $<0.004$ & $<0.004$ & 0 & 0.083 & 0.082 & 1.21 \\
\hline Phosphorus, total recoverable (mg/L) & 0.006 & 0.008 & 28.6 & 0.116 & 0.11 & 1.74 \\
\hline Organic carbon, filtered (mg/L) & 1.35 & 1.39 & 2.92 & 1.84 & 1.83 & 0.54 \\
\hline Barium, filtered $(\mu \mathrm{g} / \mathrm{L})$ & 59.3 & 59.2 & 0.17 & 61.3 & 64.8 & 5.55 \\
\hline Cadmium, filtered $(\mu \mathrm{g} / \mathrm{L})$ & 0.095 & 0.083 & 13.5 & $<0.06$ & $<0.06$ & 0 \\
\hline Copper, filtered $(\mu \mathrm{g} / \mathrm{L})$ & 1.4 & 1.5 & 6.9 & 1.4 & 1.5 & 6.9 \\
\hline Iron, total $(\mu \mathrm{g} / \mathrm{L})$ & 405 & 401 & 0.99 & 36.1 & 37.3 & 3.27 \\
\hline Lead, filtered $(\mu \mathrm{g} / \mathrm{L})$ & 0.122 & 0.122 & 0 & $<0.04$ & $<0.04$ & 0 \\
\hline Manganese, filtered $(\mu \mathrm{g} / \mathrm{L})$ & 81.3 & 79.5 & 2.24 & 2.84 & 3.3 & 15 \\
\hline Manganese, total recoverable ( $\mu \mathrm{g} / \mathrm{L})$ & 94.5 & 92.9 & 1.71 & 11.1 & 11.1 & 0 \\
\hline Silver, filtered $(\mu \mathrm{g} / \mathrm{L})$ & $<1.00$ & $<1.00$ & 0 & $<2.00$ & $<2.00$ & 0 \\
\hline Zinc, filtered $(\mu \mathrm{g} / \mathrm{L})$ & 38.3 & 38.1 & 0.52 & $<4.00$ & $<4.00$ & 0 \\
\hline Arsenic, total recoverable $(\mu \mathrm{g} / \mathrm{L})$ & 0.3 & 0.3 & 0 & 0.3 & 0.4 & 28.6 \\
\hline Selenium, filtered $(\mu \mathrm{g} / \mathrm{L})$ & 0.11 & 0.12 & 8.7 & 0.4 & 0.43 & 7.23 \\
\hline
\end{tabular}

${ }^{1}$ Relative percent difference (RPD) calculated with following equation: $\mathrm{RPD}=\{(($ larger result-smaller result $) /(($ larger result + smaller result $) / 2)) * 100\}$. 
Table 4. Summary of water-quality properties collected with water-quality samples in September 2018, Eagle County, Colorado.

$\left[\mathrm{CO}\right.$, Colorado; $\mathrm{ft}^{3} / \mathrm{s}$, cubic feet per second; ${ }^{\circ} \mathrm{C}$, degrees Celsius; $\mu \mathrm{S} / \mathrm{cm}$, microseimens per centimeter; $\mathrm{mg} / \mathrm{L}$, milligrams per liter; PAR, photosynthetically active

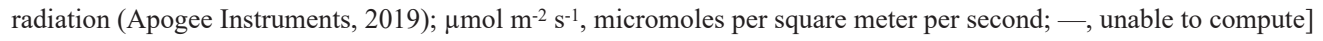

\begin{tabular}{|c|c|c|c|c|c|c|c|c|}
\hline Parameter & $\begin{array}{c}\text { Number } \\
\text { of } \\
\text { samples }\end{array}$ & Minimum & $\begin{array}{l}\text { Time of } \\
\text { minimum } 1 \\
\text { (24 hour) }\end{array}$ & Median & Maximum & $\begin{array}{c}\text { Time of } \\
\text { maximum }^{1} \\
\text { (24 hour) }\end{array}$ & $\begin{array}{c}\text { Diel } \\
\text { range }\end{array}$ & $\begin{array}{c}\text { Percent } \\
\text { diel } \\
\text { change }\end{array}$ \\
\hline \multicolumn{9}{|c|}{09064600 Eagle River near Minturn, CO } \\
\hline Streamflow, $\left(\mathrm{ft}^{3} / \mathrm{s}\right)$ & 7 & 33.0 & 1230 & 35.0 & 35.0 & ${ }^{1} 1115$ & $33.0-35.0$ & 6.1 \\
\hline Water temperature, $\left({ }^{\circ} \mathrm{C}\right)$ & 7 & 8.9 & 0500 & 9.7 & 12.6 & 1400 & $8.9-12.6$ & 41.6 \\
\hline $\mathrm{pH}$, (standard units) & 7 & 7.8 & ${ }^{1} 1900$ & 8.1 & 8.2 & ${ }^{1} 1500$ & $7.8-8.2$ & 5.1 \\
\hline PAR, modeled, $\left(\mu \mathrm{mol} \mathrm{m} \mathrm{m}^{-2} \mathrm{~s}^{-1}\right)$ & 7 & 0.0 & ${ }^{1} 0130$ & 1,272 & 1,811 & ${ }^{1} 1300$ & $0.0-1,811$ & - \\
\hline Alkalinity, $(\mathrm{mg} / \mathrm{L})$ & 7 & 85.6 & 1400 & 88.3 & 90.2 & 2000 & $85.6-90.2$ & 5.4 \\
\hline Carbon dioxide, $(\mathrm{mg} / \mathrm{L})$ & 7 & 1.0 & ${ }^{1} 1500$ & 1.5 & 2.8 & 1900 & $1.0-2.8$ & 180 \\
\hline Water temperature, $\left({ }^{\circ} \mathrm{C}\right)$ & 2 & 9.0 & 0400 & 10.8 & 12.5 & 1500 & $9.0-12.5$ & 38.9 \\
\hline Specific conductance, $(\mu \mathrm{S} / \mathrm{cm})$ & 2 & 378 & 1500 & 386 & 394 & 0400 & $378-394$ & 4.2 \\
\hline Dissolved oxygen, (mg/L) & 2 & 8.3 & 0400 & 8.8 & 9.2 & 1500 & $8.3-9.2$ & 10.8 \\
\hline $\mathrm{pH}$, (standard units) & 2 & 8.1 & 0400 & 8.4 & 8.6 & 1500 & $8.1-8.6$ & 6.2 \\
\hline PAR, modeled, $\left(\mu \mathrm{mol} \mathrm{m} \mathrm{m}^{-2} \mathrm{~s}^{-1}\right)$ & 2 & 0.0 & 0400 & 799 & 1,597 & 1500 & $0.0-1,597$ & - \\
\hline Alkalinity, (mg/L) & 2 & 123 & 1500 & 127 & 130 & 0400 & $123-130$ & 5.7 \\
\hline Carbon dioxide, $(\mathrm{mg} / \mathrm{L})$ & 2 & 0.6 & 1500 & 1.4 & 2.2 & 0400 & $0.6-2.2$ & 267 \\
\hline \multicolumn{9}{|c|}{394220106431500 Eagle River below Milk Creek near Wolcott, CO } \\
\hline Streamflow, $\left(\mathrm{ft}^{3} / \mathrm{s}\right)$ & 7 & 76.0 & 1300 & 78.0 & 80.0 & 0900 & $76.0-80.0$ & 5.3 \\
\hline Alkalinity, (mg/L) & 7 & 106 & 1600 & 126 & 129 & 0500 & $106-129$ & 21.7 \\
\hline Carbon dioxide, $(\mathrm{mg} / \mathrm{L})$ & 7 & 0.1 & ${ }^{1} 1800$ & 0.5 & 2.3 & 0500 & $0.1-2.3$ & 2,200 \\
\hline
\end{tabular}

${ }^{1}$ When minimum or maximum values occur at multiple times during the deployment, the reported time is the average of all times with the minimum or maximum value.

site, ranging from 7.8 to 8.2 (table 4), is assumed to be a result of gas transfer occurring at the water and air interface. There is a lack of biological activity at this site, which would help facilitate a biological interaction potentially causing increases and decreases in carbon dioxide. The higher levels of carbon dioxide are also supported by this site having the lowest measured water temperature during sampling (table 4), which would increase the ability to dissolve more carbon at the water and air interface, resulting in a lower $\mathrm{pH}$ value as carbon dioxide increases. Although biological activity potentially plays a role in the dissolved oxygen and carbon dioxide cycle at this site, it does not appear to be a large contributor.

Sites 09066325 and 394220106431500 also had increased carbon dioxide levels associated with the lowest $\mathrm{pH}$ value, although neither site had a measured $\mathrm{pH}$ value below 8.0 (fig. 3). However, both sites had carbon dioxide levels below $1.0 \mathrm{mg} / \mathrm{L}$ during the sampling period, which also related to dissolved oxygen levels higher than what was measured at site 09064600 (table 4), indicating additional processes were potentially occurring at these sites and not occurring at 

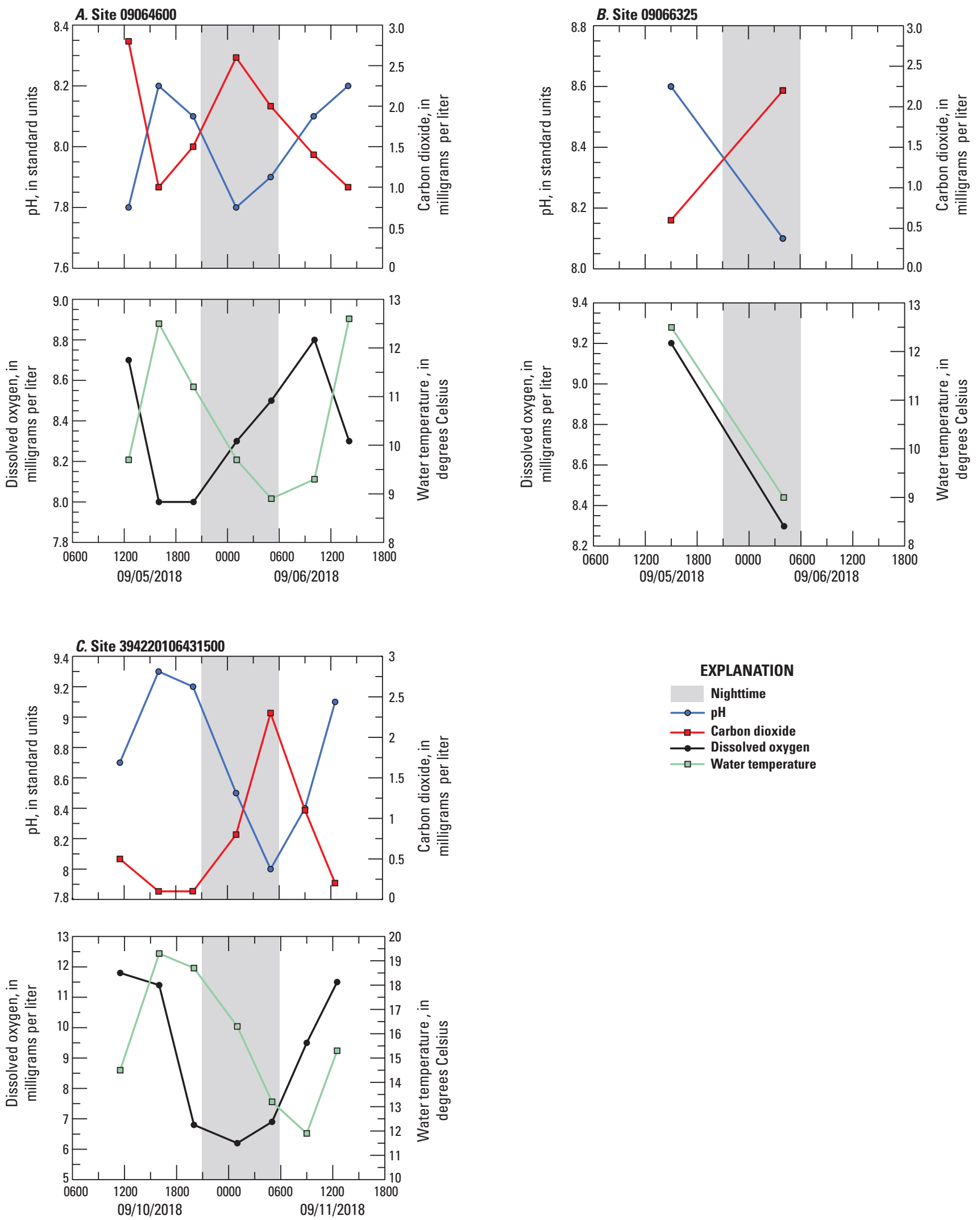

Figure 3. Diel variation of $\mathrm{pH}$, carbon dioxide, dissolved oxygen, and water temperature during water-quality sample collection September 5-11, 2018, at sites A, 09064600, B, 09066325, and C, 394220106431500, Eagle County, Colorado. 
site 09064600 . There were visibly small amounts of algal growth at site 09066325 during the sampling, which is assumed to be supplementing the gas exchange occurring at this site.

The more extreme case of these processes occurs at site 394220106431500 . There was abundant algal growth and aquatic plant growth at this site during sampling and likely allowed for a pronounced effect from photosynthesis and respiration. Although the minimum $\mathrm{pH}$ value was similar to the value at site 09066325 , with similar carbon dioxide levels, the maximum $\mathrm{pH}$ and dissolved oxygen levels at this site were higher in comparison (fig. 3, table 4). Carbon dioxide levels dropped to $0.1 \mathrm{mg} / \mathrm{L}$ during the day, indicating photosynthesis was actively consuming as much carbon dioxide as possible, resulting in the highest $\mathrm{pH}$ measured during the sampling event of 9.3 (fig. 3).

There was noticeable variation between sites in dissolved oxygen concentrations in water-quality sample data. All three sites displayed higher dissolved oxygen levels during the day and lower dissolved oxygen at night (fig. 3). Sites 09064600 (dissolved oxygen ranged from 8.0 to $8.8 \mathrm{mg} / \mathrm{L}$ [100 to 102 percent saturation] with the maximum value on September 6, 2018, at 1000 and the minimum value on September 5, 2018, at 1600 and on September 5, 2018, at 2000) and 09066325 (dissolved oxygen ranged from 8.3 to $9.2 \mathrm{mg} / \mathrm{L}$ [ 95 to 115 percent saturation] with the maximum value on September 5, 2018, at 1500 and the minimum value on September 6, 2018, at 0400) exhibited similar ranges in dissolved oxygen concentrations, and all concentrations were near 100 percent saturation during the day and at night (fig. 3, table 4). Site 09066325 had a slightly wider range in values during the sample period than site 09064600. Site 394220106431500 had the greatest diel range, from $6.2 \mathrm{mg} / \mathrm{L}$ to $11.8 \mathrm{mg} / \mathrm{L}$ (82 to 149 percent saturation), with the minimum value occurring in the early morning on September 11, 2018, at 0100, and the maximum value occurring on September 10, 2018, at 1130 (table 4). This site also had the highest percent saturation of 160 on September 10, 2018, at 1600 when dissolved oxygen concentration was $11.4 \mathrm{mg} / \mathrm{L}$ and water temperature was $19.3^{\circ} \mathrm{C}$ (fig. 3). This pattern is consistent with photosynthesis and respiration by algae and aquatic plants causing decreases in $\mathrm{CO}_{2}$ during the day when photosynthesis occurs and increases in $\mathrm{CO}_{2}$ and decreases in dissolved oxygen at night when photosynthesis ceases and respiration dominates. This transition appears to happen quickly at this site, with dissolved oxygen concentrations dropping from $11.4 \mathrm{mg} / \mathrm{L}$ at 1600 to $6.8 \mathrm{mg} / \mathrm{L}$ at 2000 , dropping by $4.6 \mathrm{mg} / \mathrm{L}$ in 4 hours (fig. 3), resulting in a 40 percent reduction in dissolved oxygen. Dissolved oxygen levels remained in the low to mid- $6.0 \mathrm{mg} / \mathrm{L}$ range until about 0500 at the beginning of sunrise and then rising rapidly to more than $11.0 \mathrm{mg} / \mathrm{L}$ by 1200 the next day (fig. 3). The same daily pattern found in the discrete samples is evident in the daily pattern during the 2018 water-quality monitoring data. Figure 4 illustrates the 2018 water-quality data with the discrete water-quality samples and the relation between the measured dissolved oxygen and the theoretical 100-percent saturation concentration.

\section{Diel Cycle and Magnitude in Nutrients}

Various nutrient concentrations were evaluated for diel cycles at sites 09064600,09066325 , and 394220106431500 (table 5). Many of the nutrient concentrations at sites 09064600 and 09066325 were below the laboratory reporting limits. Diel cycles were observed in most of the nutrients sampled at site 394220106431500 (table 5). The diel change in filtered nitrate plus nitrite was 179 percent, with concentrations ranging from 0.24 to $0.67 \mathrm{mg} / \mathrm{L}$. Most filtered nitrate plus nitrite is filtered nitrate, which increased 175 percent with concentrations ranging from 0.24 to $0.66 \mathrm{mg} / \mathrm{L}$. There was also an appreciable 77.4 percent increase in the diel concentration of total nitrogen, ranging from 0.53 to $0.94 \mathrm{mg} / \mathrm{L}$. The diel increase in filtered orthophosphate was 71.4 percent, with concentrations ranging from 0.07 to $0.12 \mathrm{mg} / \mathrm{L}$. Total phosphorus also had a diel increase of 50 percent, with concentrations ranging from 0.10 to $0.15 \mathrm{mg} / \mathrm{L}$ (table 5).

Comparisons of the diel cycles in nutrients at site 394220106431500 indicated the general shape of the diel cycle for most of the nutrients were similar, and filtered nitrate plus nitrite was used to illustrate this relation (fig. 5). Nutrient concentrations tend to be highest during the 1200 hour and then decreased through the rest of the afternoon. Concentrations tended to be lowest around sunset, which occurred near 1900 during the sampling, and rose steadily through the nighttime hours and early morning before again reaching the maximum daily value again near 0900 (fig. 5). This diel pattern was consistent with the expected pattern associated with photosynthesis and respiration and denitrification and nitrification cycles described in Nimick and others (2011) and as described in the Photosynthesis and Nutrients sections of this report.

Determining whether photosynthesis, nitrification, or denitrification is the dominant process affecting the diel cycle in nutrients is difficult. Most likely, it is a combination of all processes working in tandem. In addition, because of the oxygenated environment, nitrification, which occurs in aerobic environments, is presumed to be the dominant mechanism in the denitrification and nitrification cycle at this site. However, denitrification could be occurring below the bed surface if conditions are anoxic. Low ammonia levels, below reporting level, during the day, followed by an increase in ammonia after the sunset are indications nitrification is occurring rapidly during the day (Johnson and Tank, 2009).

\section{Diel Cycle and Magnitude in Trace Elements}

Numerous trace elements were evaluated at sites 09066325, 09064600, and 394220106431500. Many of the trace elements collected at site 09066325 were below 

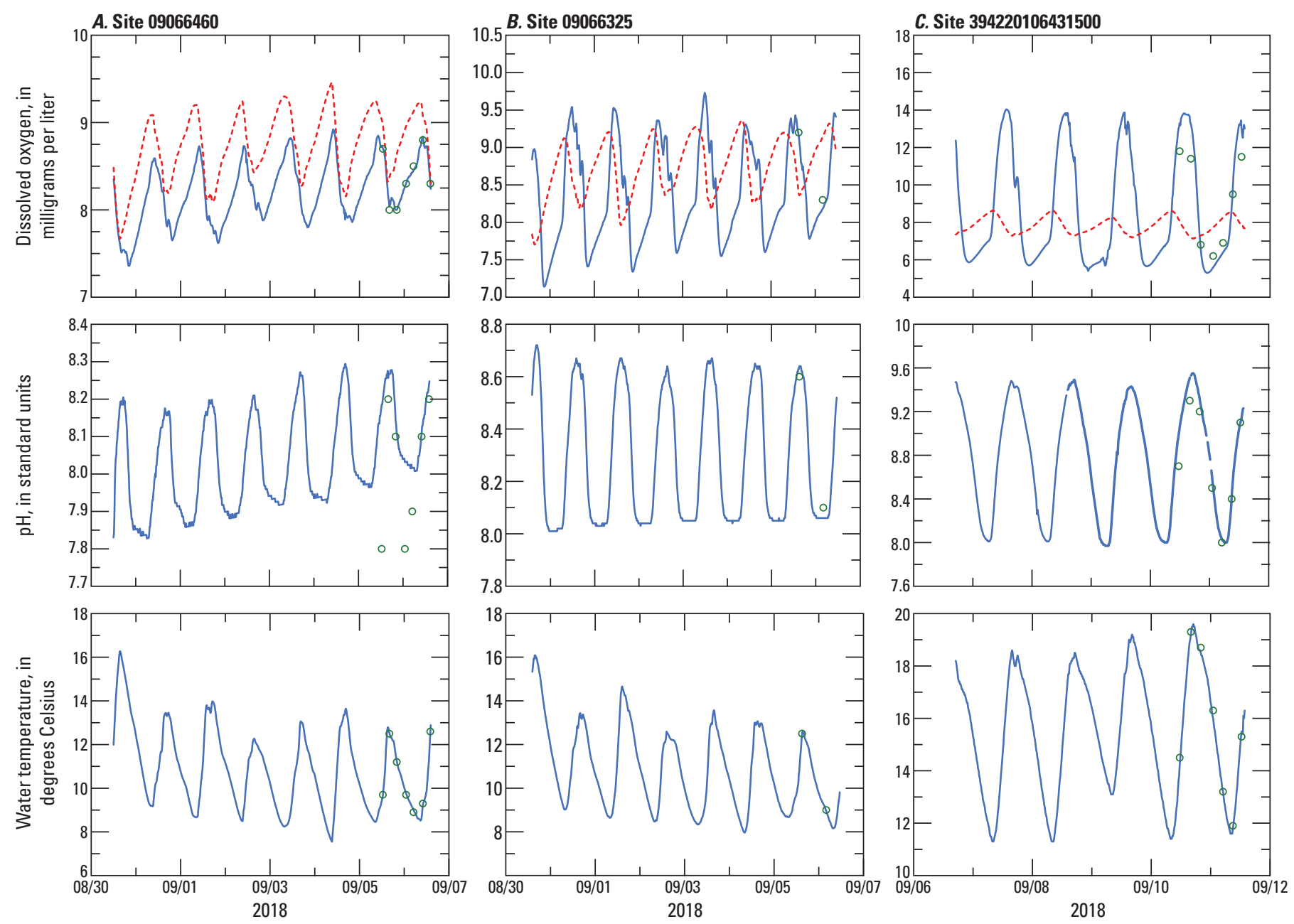

EXPLANATION

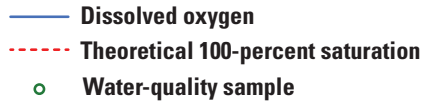

Figure 4. Water-quality monitoring data measured in August and September 2018, in conjunction with water-quality sampling at sites $A, 09064600, B, 09066325$, and $C, 394220106431500$, Eagle County, Colorado. The 100-percent saturation concentration values calculated using the USGS dissolved oxygen solubility tables documented in the USGS National Field Manual (Radtke and others, 1998).

the reporting limit and could not be assessed for diel cycles. Filtered barium, total recoverable iron, filtered manganese, total recoverable manganese, and filtered selenium had measurable concentrations that could be evaluated for diel cycles (table 6). Filtered barium, filtered manganese, and filtered selenium had small changes in concentrations (percent magnitude), of 115-121 $\mu \mathrm{g} / \mathrm{L}$ (5.2 percent), 1.44-1.72 $\mu \mathrm{g} / \mathrm{L}$ (19.4 percent), and $0.25-0.28 \mu \mathrm{g} / \mathrm{L}$ (12.0 percent), respectively. Total recoverable iron had the largest measured diel cycle at site 09066325 , with a diel cycle increasing greater than 94 percent, with concentrations ranging from $<10$ to
$19.4 \mu \mathrm{g} / \mathrm{L}$. Total recoverable manganese also had a notable diel increase of 50 percent, with concentrations ranging from 1.80 to $2.70 \mu \mathrm{g} / \mathrm{L}$ (table 6 ).

Sites 09064600 and 394220106431500 had few parameter values below reporting limits, and many of the parameters had measured values that could be assessed for a diel cycle (table 6). Concentrations were generally lower at site 394220106431500 than at site 09064600 (table 6). This pattern is assumed to be from dilution as the water travels 
Table 5. Summary of nutrient data collected at three sites in the Eagle River Basin, September 2018, Eagle County, Colorado.

[CO, Colorado; N, nitrogen; mg/L, milligrams per liter; P, phosphorus; <, less than; >, greater than; +, plus; - , value not calculated]

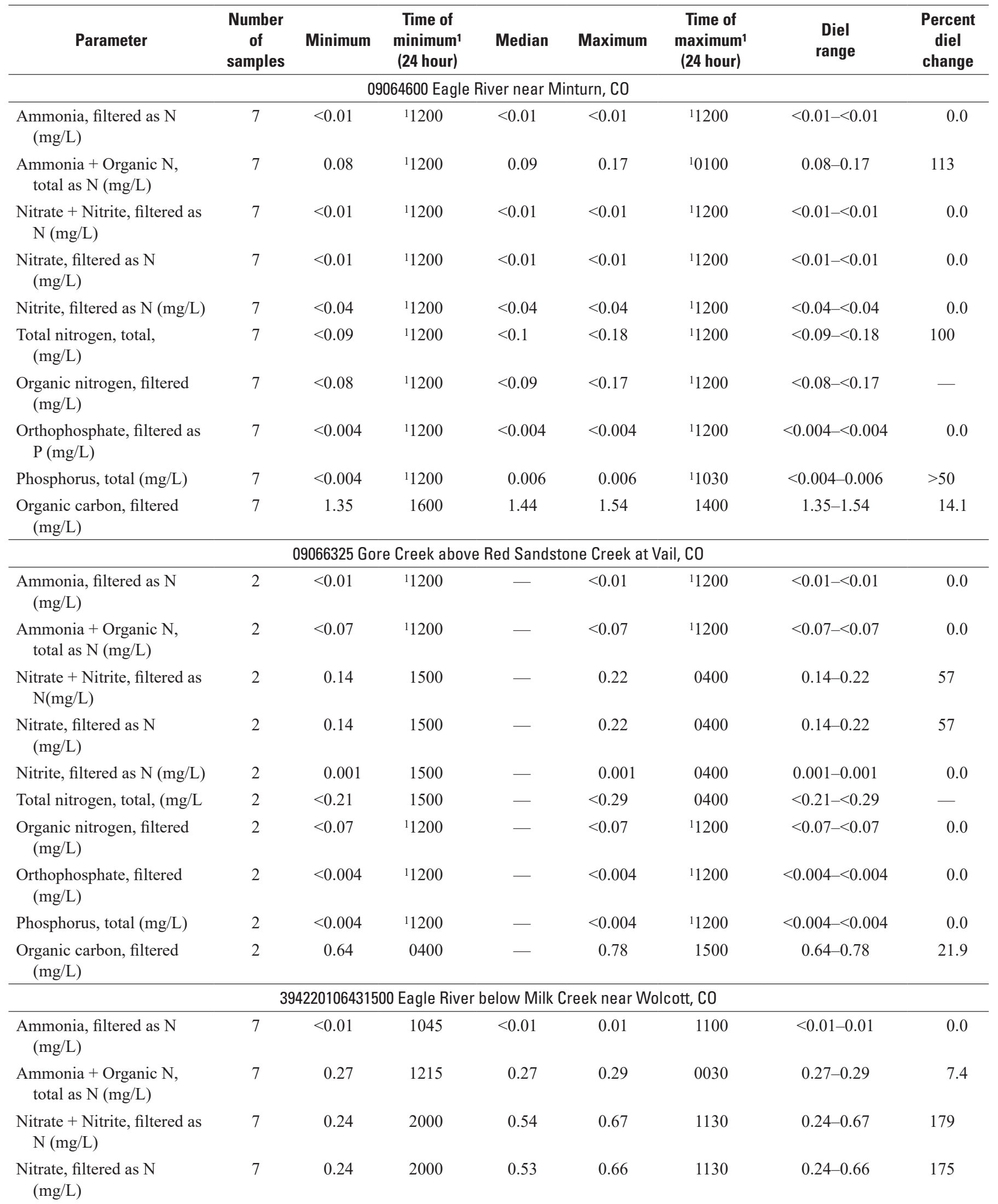


Table 5. Summary of nutrient data collected at three sites in the Eagle River Basin, September 2018, Eagle County, Colorado.Continued

[CO, Colorado; N, nitrogen; mg/L, milligrams per liter; P, phosphorus; <, less than; >, greater than; +, plus; —, value not calculated]

\begin{tabular}{|c|c|c|c|c|c|c|c|c|}
\hline Parameter & $\begin{array}{c}\text { Number } \\
\text { of } \\
\text { samples }\end{array}$ & Minimum & $\begin{array}{c}\text { Time of } \\
\text { minimum } 1 \\
\text { (24 hour) }\end{array}$ & Median & Maximum & $\begin{array}{c}\text { Time of } \\
\text { maximum }{ }^{1} \\
\text { (24 hour) }\end{array}$ & $\begin{array}{c}\text { Diel } \\
\text { range }\end{array}$ & $\begin{array}{c}\text { Percent } \\
\text { diel } \\
\text { change }\end{array}$ \\
\hline Nitrite, filtered as $\mathrm{N}(\mathrm{mg} / \mathrm{L})$ & 7 & 0.007 & 2000 & 0.012 & 0.014 & 0100 & $0.007-0.014$ & 100 \\
\hline Total nitrogen, total, $(\mathrm{mg} / \mathrm{L}$ & 7 & 0.53 & 2000 & 0.83 & 0.94 & 1130 & $0.53-0.94$ & 77.4 \\
\hline $\begin{array}{l}\text { Organic nitrogen, filtered } \\
\quad(\mathrm{mg} / \mathrm{L})\end{array}$ & 7 & 0.26 & 1600 & 0.27 & 0.28 & 0500 & $0.26-0.28$ & 7.7 \\
\hline Phosphorus, total (mg/L) & 7 & 0.10 & 2000 & 0.14 & 0.15 & 1130 & $0.10-0.15$ & 50 \\
\hline $\begin{array}{l}\text { Organic carbon, filtered } \\
\quad(\mathrm{mg} / \mathrm{L})\end{array}$ & 7 & 1.65 & 0900 & 1.73 & 1.84 & 1600 & $1.65-1.84$ & 11.5 \\
\hline
\end{tabular}

${ }^{1}$ When minimum or maximum values occur at multiple times during the deployment, the reported time is the average of all times with the minimum or maximum value. Parameters with censored minimum and maximum values were given a time of 1200 to represent the middle of the day.
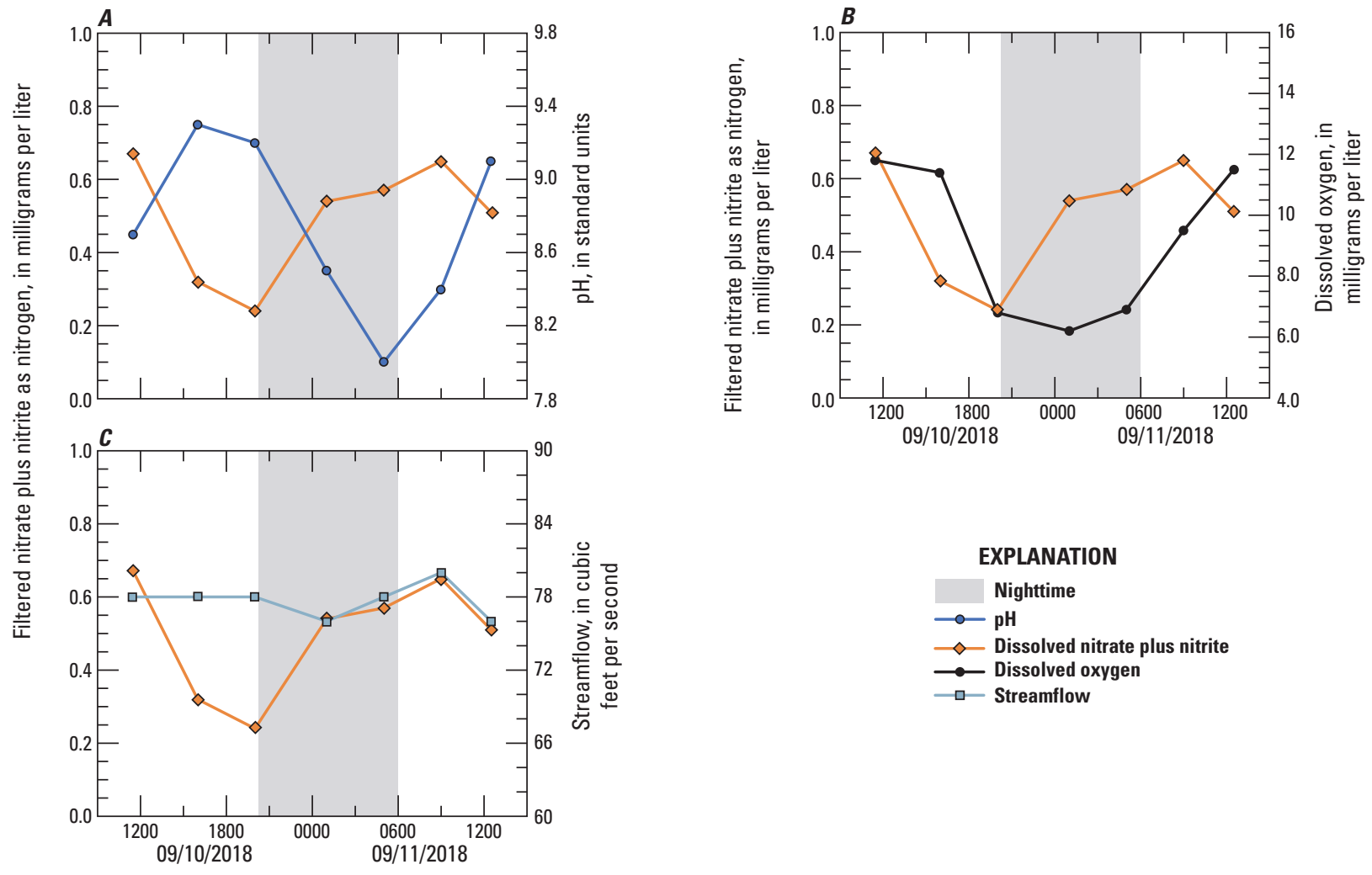

Figure 5. Filtered nitrate plus nitrite concentrations and $A, \mathrm{pH}, B$, dissolved oxygen, and $C$, streamflow measurements from water-quality samples collected September 10-11, 2018, at site 394220106431500, Eagle County, Colorado. 
Table 6. Summary of trace-element data collected at three sites in the Eagle River Basin, September 2018, Eagle County, Colorado.

$[\mathrm{CO}$, Colorado; total, total recoverable; $\mu \mathrm{g} / \mathrm{L}$, micrograms per liter; $<$, less than; $>$, greater than; - , value not calculated]

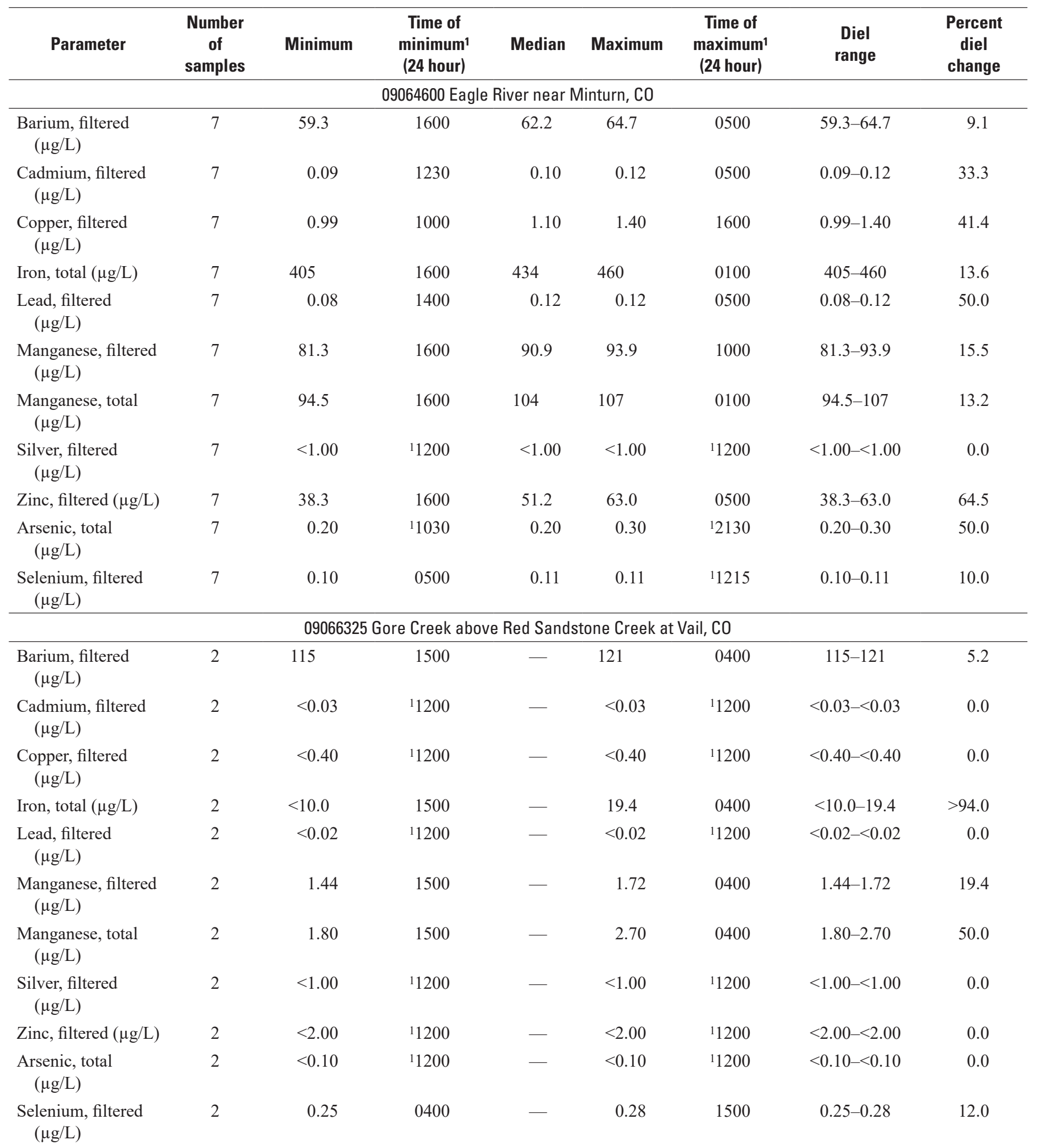


Table 6. Summary of trace-element data collected at three sites in the Eagle River Basin, September 2018, Eagle County, Colorado.Continued

$[\mathrm{CO}$, Colorado; total, total recoverable; $\mu \mathrm{g} / \mathrm{L}$, micrograms per liter; $<$, less than; >, greater than; —, value not calculated]

\begin{tabular}{|c|c|c|c|c|c|c|c|c|}
\hline Parameter & $\begin{array}{c}\text { Number } \\
\text { of } \\
\text { samples }\end{array}$ & Minimum & $\begin{array}{c}\text { Time of } \\
\text { minimum }{ }^{1} \\
\text { (24 hour) }\end{array}$ & Median & Maximum & $\begin{array}{c}\text { Time of } \\
\text { maximum } 1 \\
\text { (24 hour) }\end{array}$ & $\begin{array}{c}\text { Diel } \\
\text { range }\end{array}$ & $\begin{array}{c}\text { Percent } \\
\text { diel } \\
\text { change }\end{array}$ \\
\hline \multicolumn{9}{|c|}{394220106431500 Eagle River below Milk Creek near Wolcott, CO } \\
\hline $\begin{array}{l}\text { Barium, filtered } \\
\qquad(\mu \mathrm{g} / \mathrm{L})\end{array}$ & 7 & 61.3 & 1600 & 64.5 & 68.4 & 0500 & $61.3-68.4$ & 11.6 \\
\hline $\begin{array}{l}\text { Cadmium, filtered } \\
(\mu \mathrm{g} / \mathrm{L})\end{array}$ & 7 & $<0.06$ & ${ }^{1} 1200$ & $<0.06$ & $<0.06$ & ${ }^{1} 1200$ & $<0.06-<0.06$ & 0.0 \\
\hline $\begin{array}{l}\text { Copper, filtered } \\
\qquad(\mu \mathrm{g} / \mathrm{L})\end{array}$ & 7 & 0.98 & 0900 & 1.10 & 1.40 & 1600 & $0.98-1.40$ & 42.9 \\
\hline Iron, total $(\mu \mathrm{g} / \mathrm{L})$ & 7 & 33.1 & 1130 & 36.5 & 39.8 & 2000 & $33.1-39.8$ & 20.2 \\
\hline $\begin{array}{l}\text { Lead, filtered } \\
\qquad(\mu \mathrm{g} / \mathrm{L})\end{array}$ & 7 & $<0.04$ & ${ }^{1} 1200$ & $<0.04$ & $<0.04$ & ${ }^{1} 1200$ & $<0.04-<0.04$ & 0.0 \\
\hline $\begin{array}{l}\text { Manganese, filtered } \\
(\mu \mathrm{g} / \mathrm{L})\end{array}$ & 7 & 2.84 & 1600 & 6.18 & 10.9 & 0100 & $2.84-10.9$ & 284 \\
\hline $\begin{array}{l}\text { Manganese, total } \\
(\mu \mathrm{g} / \mathrm{L})\end{array}$ & 7 & 9.70 & 1130 & 14.7 & 19.5 & 0500 & $9.70-19.5$ & 101 \\
\hline $\begin{array}{l}\text { Silver, filtered } \\
\qquad(\mu \mathrm{g} / \mathrm{L})\end{array}$ & 7 & $<2.00$ & ${ }^{1} 1200$ & $<2.00$ & $<2.00$ & ${ }^{1} 1200$ & $<2.00-<2.00$ & 0.0 \\
\hline Zinc, filtered $(\mu \mathrm{g} / \mathrm{L})$ & 7 & $<4.00$ & ${ }^{1} 1600$ & 4.10 & 5.50 & 0700 & $<4.00-5.50$ & $>37.5$ \\
\hline $\begin{array}{l}\text { Arsenic, total } \\
\quad(\mu \mathrm{g} / \mathrm{L})\end{array}$ & 7 & 0.30 & ${ }^{1} 1100$ & 0.30 & 0.40 & 1130 & $0.30-0.40$ & 33.3 \\
\hline $\begin{array}{l}\text { Selenium, filtered } \\
\qquad(\mu \mathrm{g} / \mathrm{L})\end{array}$ & 7 & 0.37 & 0500 & 0.41 & 0.43 & 2000 & $0.37-0.43$ & 16.2 \\
\hline
\end{tabular}

${ }^{1}$ When minimum or maximum values occur at multiple times during the deployment, the reported time is the average of all times with the minimum or maximum value. Parameters with censored minimum and maximum values were given a time of 1200 to represent the middle of the day.

downstream away from the source locations along with additional biological and chemical processes potentially removing trace elements from the water column.

The majority of the trace elements observed at site 09064600 displayed some amount of diel cycling. Diel cycles tended to increase about 10-65 percent across all the trace elements during the sampling period (table 6). Trace elements with appreciable diel cycles during the sampling period included filtered cadmium, filtered copper, and filtered zinc. Filtered cadmium increased 33.3 percent with concentrations ranging from 0.09 to $0.12 \mu \mathrm{g} / \mathrm{L}$. The diel cycle in filtered copper increased 41.4 percent during the sampling period, ranging from 0.99 to $1.40 \mu \mathrm{g} / \mathrm{L}$. Filtered zinc had the largest change in concentration, increasing 64.5 percent, with concentrations ranging from 38.3 to $63.0 \mu \mathrm{g} / \mathrm{L}$ (table 6). Filtered cadmium and zinc showed concentration maxima at night, and minima after noon consistent with expected behavior for cations reported in other studies (Nimick and others, 2011). However, filtered copper had maxima in the afternoon and minima in the morning. Total arsenic increased 50 percent with concentrations ranging from 0.2 to $0.3 \mu \mathrm{g} / \mathrm{L}$ and displayed an inverse relation to the trace elements with maxima near sunset and minima after sunrise.
Total recoverable iron, filtered manganese, and filtered zinc all followed a similar diel pattern during the sampling period at site 09064600 . The maximum concentrations occurred during the nighttime or early morning period with some variation between the parameters regarding the timing of the peak concentration observed. Total recoverable iron had a peak concentration near 0100 , filtered zinc peaked at 0500 , just before sunrise, and filtered manganese peaked at about 1000, midmorning. The minimum concentrations for all three parameters occurred in the late afternoon, around 1600 (table 6; fig. 6).

Filtered copper, filtered manganese, total recoverable manganese, and filtered zinc had the most appreciable diel cycles during the sampling period at site 394220106431500 (table 6). The diel cycle in filtered copper was similar to site 09064600 with an increase of about 41.4 percent and concentrations ranging from 0.99 to $1.40 \mu \mathrm{g} / \mathrm{L}$. Filtered manganese, followed by total recoverable manganese, had the largest change in concentrations with increases of 284 and 101 percent, respectively; concentrations ranged from 2.84 to $10.9 \mu \mathrm{g} / \mathrm{L}$ for filtered manganese, whereas concentrations for total recoverable manganese ranged from 9.70 to $19.5 \mu \mathrm{g} / \mathrm{L}$. The diel cycle for filtered zinc increased greater than 37.5 percent, with concentrations ranging 

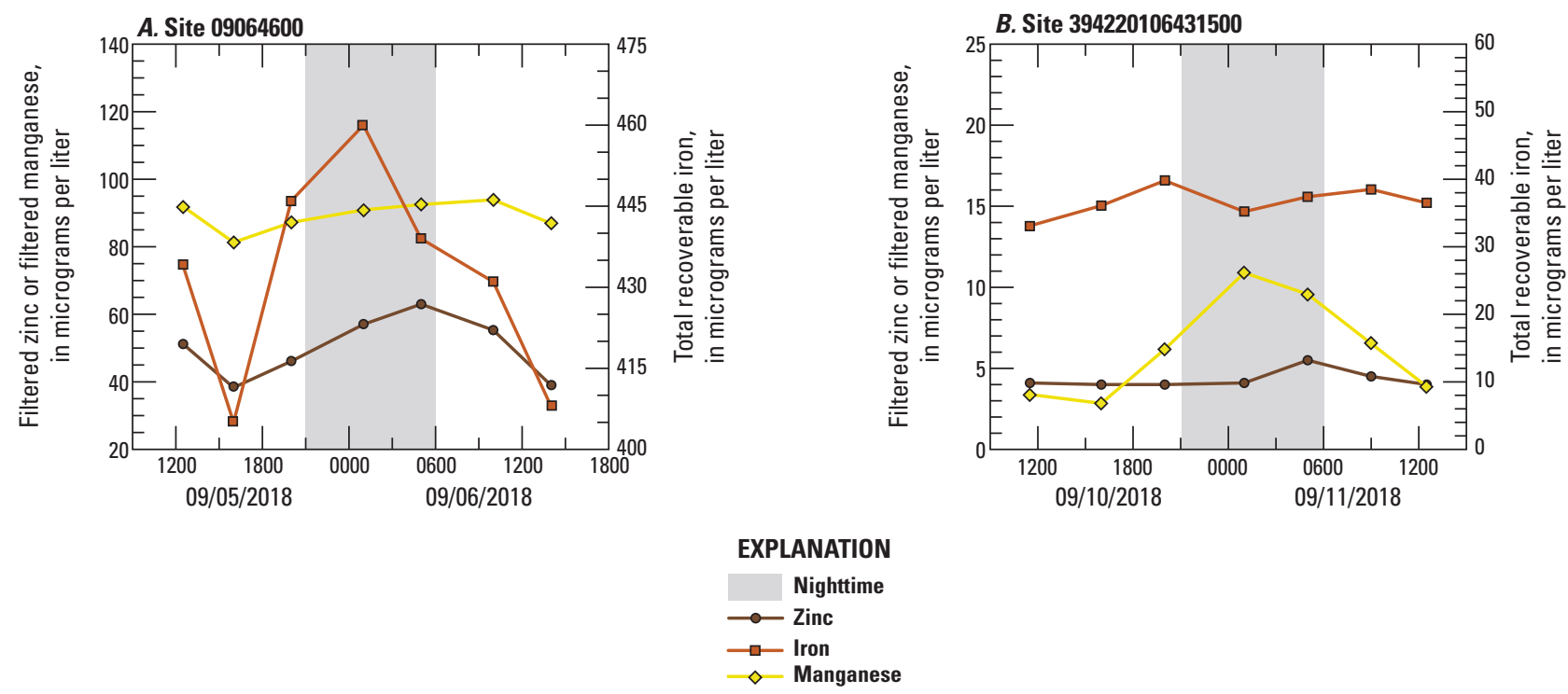

Figure 6. Diel variation of filtered zinc, filtered manganese, and total recoverable iron in water-quality samples collected at sites $A, 09064600$ and $B, 394220106431500$ from September 10-11, 2018, Eagle County, Colorado.

from $<4.00$ to $5.5 \mu \mathrm{g} / \mathrm{L}$ (table 6 ). Filtered manganese, total manganese, and filtered zinc showed concentration maxima at night, or near sunrise. Filtered copper had maxima in the afternoon. Filtered manganese, total manganese, and filtered zinc had minimum values at noon, or in the afternoon; whereas copper had minimum values in the morning, consistent with expected behavior for cations reported in other studies (Nimick and others, 2011). Total arsenic showed little variability in concentration at this site, with 6 of the 7 samples collected having the same value of $0.30 \mu \mathrm{g} / \mathrm{L}$. Filtered selenium had a little more variability increasing 16.2 percent, ranging from 0.37 to $0.43 \mu \mathrm{g} / \mathrm{L}$. The maximum values for filtered selenium were measured late evening, and the minimum values were measured just before sunrise (table 6).

At site 394220103431500 , the diel cycle for filtered zinc had similar timing to site 09064600 , with the peak concentrations occurring during the nighttime period (fig. 6). In contrast, total recoverable iron showed a maximum concentration just prior to sunset, and filtered manganese had its highest concentration at 0100 instead of just after sunrise. The minimum concentrations for all three constituents were in the late morning to early afternoon (1130-1230) during the sampling period (fig. 6).

There was generally an inverse relation among $\mathrm{pH}$ and filtered manganese and zinc concentrations at sites 09064600 and 394220106431500 (fig. 7). The highest concentrations of trace elements generally occurred during the nighttime period, typically in the early morning hours when $\mathrm{pH}$ was nearing or at its lowest value for the day (fig. 7). At site 09064600, the lowest manganese and zinc concentrations coincided with the highest $\mathrm{pH}$ value at around 1600 . The maximum concentrations lagged after $\mathrm{pH}$ reached its lowest value around 0100 , not reaching maximum concentration until early morning (0500 for zinc and 1000 for manganese) (fig. 7). At site 394220106431500 , the inverse relation between $\mathrm{pH}$ and cycling of filtered manganese and filtered zinc was more synchronized, and consistent with previous studies. The minimum filtered manganese concentration occurred in the midafternoon (1600) when $\mathrm{pH}$ was at its maximum value (fig. 7). Concentrations increased steadily through the late evening and into the night as $\mathrm{pH}$ decreased, peaking at 0100 for filtered manganese and 0500 for filtered zinc. The maximum concentration for filtered zinc matches the timing associated with the minimum $\mathrm{pH}$ value (fig. 7). Low concentrations of filtered zinc at this site limit the ability to detect a complete diel cycle as three samples were less than the detection limit of $4 \mu \mathrm{g} / \mathrm{L}$.

Mechanisms controlling diel cycles of filtered manganese and zinc in figures 6 and 7 likely include adsorption and manganese redox reactions. Both processes are highly $\mathrm{pH}$ dependent, and the data indicate trace-element concentrations generally parallel $\mathrm{pH}$ changes. Because of the rapid decrease in concentration as $\mathrm{pH}$ increases, it is likely adsorption is happening at a rapid rate at sites (Nimick and others, 2003). Interestingly, the separation of proton attraction through deprotonation does not appear to be as rapid and appears to be more delayed at site 09064600 and could be a result of manganese oxidation reactions creating additional surfaces for adsorption to occur. Once $\mathrm{pH}$ begins to drop and manganese becomes reduced, it returns to a dissolved form in the water column. This process could potentially be more gradual and result in a more gradual release of not only manganese, but other trace elements using the precipitated manganese as adsorption locations, reverting to a dissolved state (Nimick and others, 2003; Fuller and Harvey, 2000; Brick and Moore, 1996). Based on the ratio of filtered manganese concentration to filtered zinc concentration being much greater than one at 0904600 (an indicator to determine if manganese redox could 

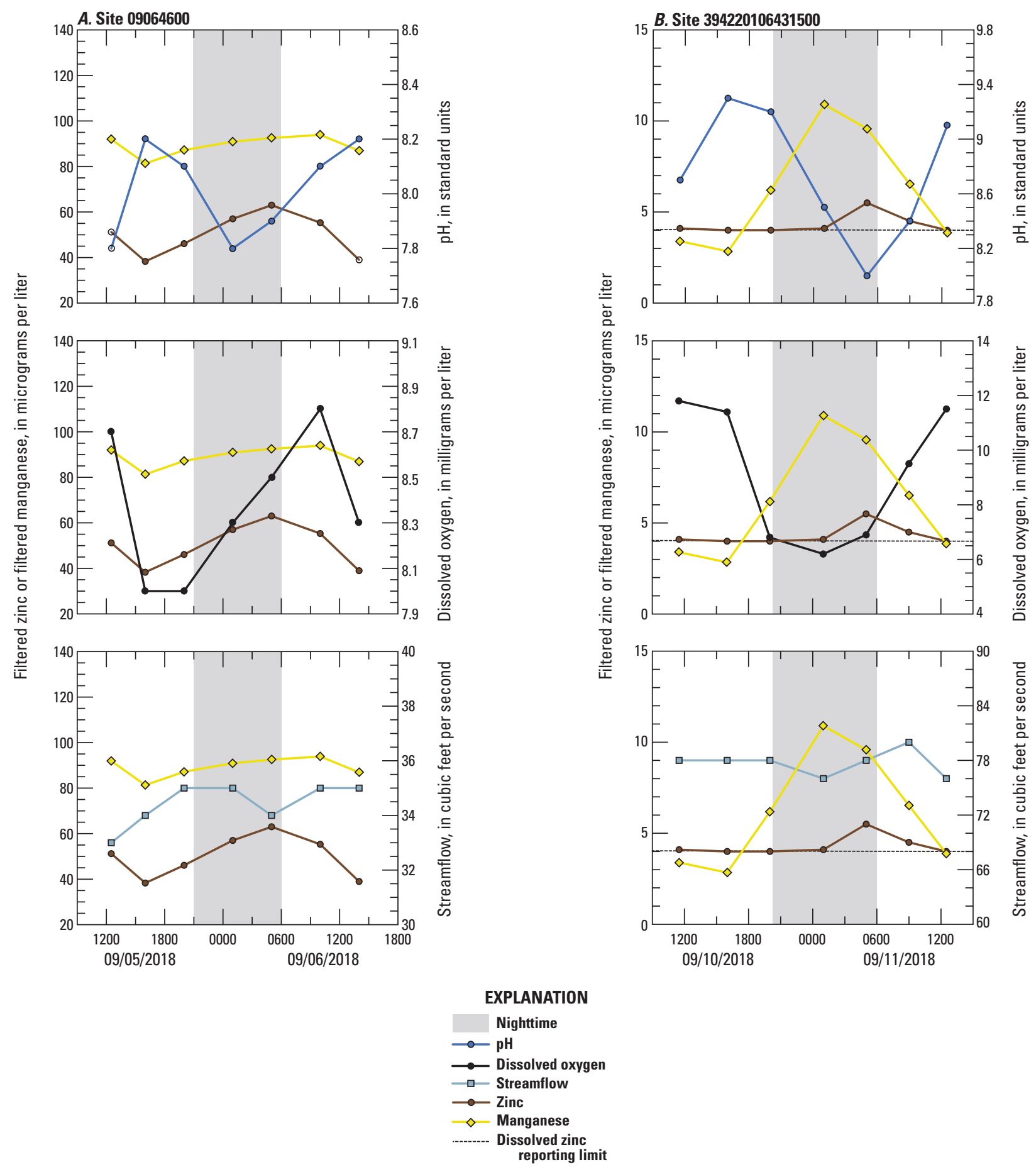

Figure 7. Diel variation of filtered manganese and zinc in relation to $\mathrm{pH}$, dissolved oxygen, and streamflow measured in relation to water-quality samples collected at sites $A, 09064600$ and $B, 394220106431500$ from September 10-11, 2018, Eagle County, Colorado. 
be occurring [Nimick and others, 2003]), the process of manganese redox reactions is plausible and could potentially be enhancing the effectiveness of adsorption in the system.

The mechanism controlling the diel cycle of trace elements at site 394220106431500 is most likely adsorption and manganese redox reactions. There is strong response in concentrations to changes in $\mathrm{pH}$ indicating the protonation and deprotonation of binding surfaces and the physical binding and unbinding of ions to these surfaces is happening rapidly. Manganese redox reactions may also be occurring at this site, creating additional adsorption locations for other element ions to bind to. The observed fluctuations in manganese concentrations (filtered and total recoverable) during the sampling period are potentially a result of manganese redox reactions occurring at this site (fig. 8). The additional adsorption locations provided by abundant biofilm and algae at this site could also enhance the effectiveness of adsorption. Although it is difficult to single out a process controlling the diel cycle of trace elements at this site, it is most likely a combination of multiple processes affecting diel variation of trace elements.

\section{Effects of Diel Cycling on Water- Quality Monitoring}

Characterization of nutrient and trace-element concentration ranges in streams is accomplished by data collection for a broad range of hydrologic conditions. Water quality is commonly used to characterize baseline conditions, identify contaminant sources, evaluate cleanup, monitor long-term effects, and evaluate risk to aquatic organisms. The presence of persistent and substantial diel cycles during routine data collection can lead to biased representations of data distributions that, in turn, can lead to in misinformed decisions (Nimick and others, 2011).

Historical sampling efforts are typically restricted to the workday hours, with most sampling activity between 0800 and 1700. A frequency distribution of historical samples at site 09064600 indicates two distinct time periods when sampling occurs, between 0900 and 1100, and 1400 and 1600 (fig. 9). From 2014 to 2018, 11 of 51 samples, about 22 percent, were collected between 0900 and 1100 . Typically, data collection in the afternoon is more common throughout the history of sampling activity at this site; however, fewer samples were collected during the afternoon in the last five years, as sampling during the morning increased (fig. 9) (U.S. Geological Survey, 2019a).

The frequency distribution of historical sampling at site 394220106431500 indicates a broad range of times when sampling occurs. Sampling occurs most frequently between 1100 and 1600 accounting for 66 percent of the historical samples. Remaining samples were collected earlier in the morning, between 0800 and 1000, and later in the afternoon, between 1600 and 1700 (fig. 9).

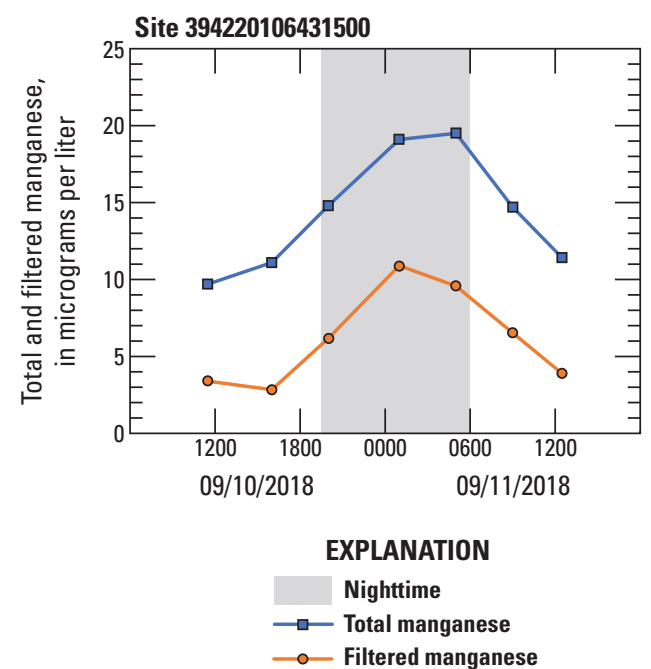

Figure 8. Comparison of total manganese and filtered manganese concentrations in water-quality samples collected September 10-11, 2018, at site 394220106431500, Eagle County, Colorado.

When results from the September 2018 sampling are plotted with the frequency graphs, the effect of sample timing is clearer (fig. 9). Although the concentrations associated with the sampling are only a small window in time compared to the multiple years and multiple seasons represented in the frequency plots, they demonstrate how diel cycling can affect sampling results. At site 09064600 , where trace elements are in higher concentrations, the diel cycle in filtered manganese and filtered zinc illustrate how sample timing can create a bias in the resulting data. During the peak sampling times, concentrations vary from a near maximum daily value to a minimum daily value, generating a bias depending on what time of day the samples are collected (fig. $9 A$ ). Similar to site 09064600 , site 394220106431500 illustrates how concentrations can vary, and how the historical sample distribution could be creating a low bias in the dataset. Using filtered manganese as a representative for the trace elements, the peak sampling times match up to the lowest sample concentration as part of the September 2018 sampling (fig. 9B). However, nitrate plus nitrite, may be near its peak value in the late morning and early afternoon, before decreasing sharply in late afternoon (fig. 9B). Although the sample concentrations plotted with the frequency curves are only a small representation of what is occurring seasonally or between separate years, they illustrate the timing of water-quality sampling in the presence of diel cycles can potentially bias the data and affect the interpretation of data results.

Analysis of historical samples and the sample collection time at site 09064600 and 394220106431500 indicate there is the potential for diel cycles through the historical period. At site 09064600 , analysis of filtered manganese and filtered zinc show patterns suggestive of a diel pattern, similar to the pattern illustrated in figure 7, have occurred historically 

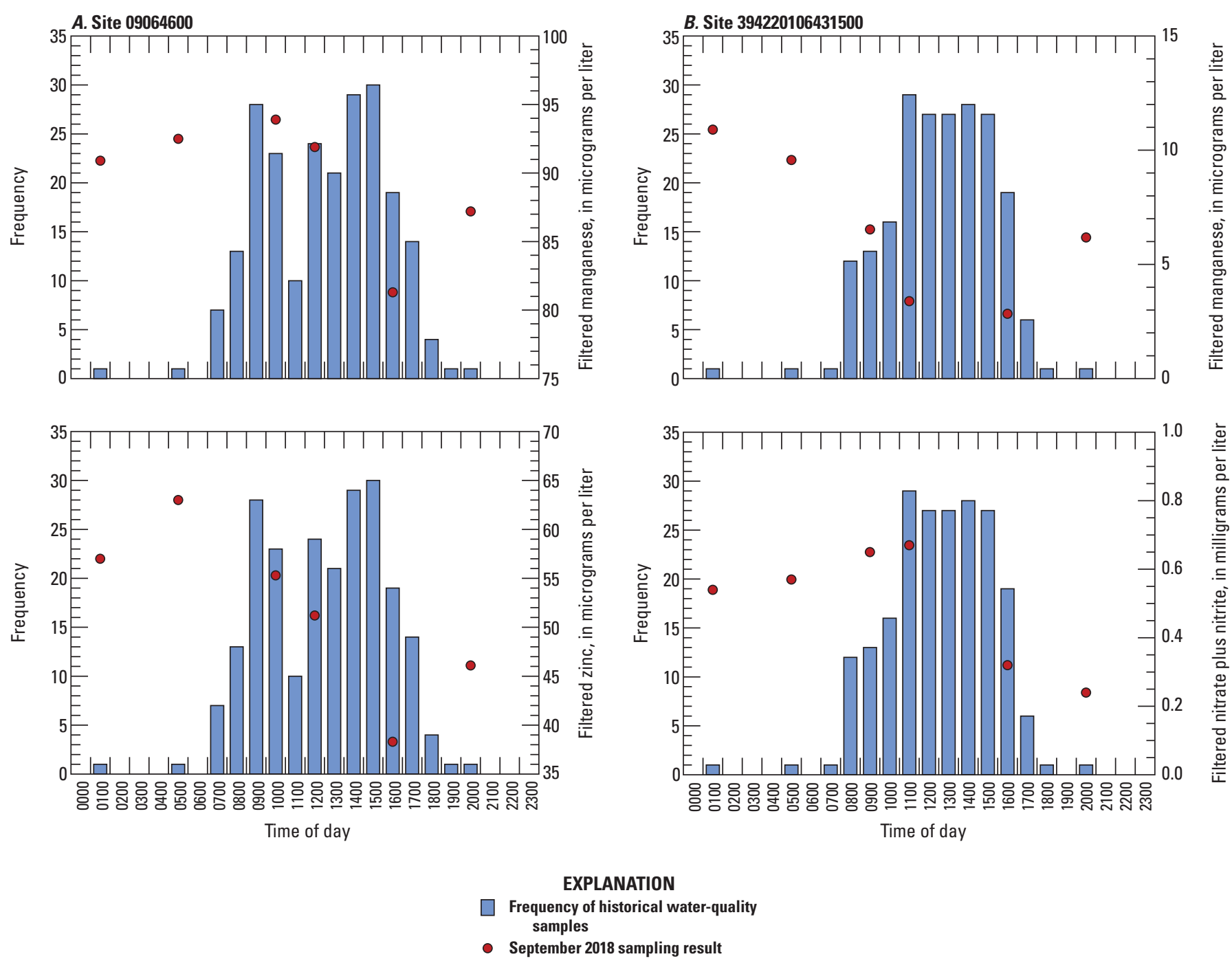

Figure 9. Frequency of historical water-quality samples in terms of time of day at sites $A, 09064600$ and $B, 394220106431500$ with sampling results from September 2018 included, Eagle County, Colorado.

(fig. 10A). There are instances where concentrations of filtered manganese are higher when samples are collected earlier in the day and lower when samples are collected later in the afternoon. However, there are some samples appearing to have the opposite behavior. Similar patterns between concentrations and sample collection time is visible at site 394220106431500 in filtered manganese and filtered nitrate plus nitrate (fig. 10B). Lower median concentrations in filtered manganese tend to be associated with sample times later in the day and many higher concentrations that appear to be associated with samples collected earlier it the day. The relation is not as clear in filtered nitrate plus nitrite; however, there are still numerous occasions where concentrations vary with the time of day they were collected (fig. 10B).
A key detail is samples collected during one 24-hour period, during a specific time of the year, do not represent what is happening during the course of an entire year. The relations between time of day and sample concentrations could be a result of many factors. The most pronounced factor is streamflow and its effect on concentrations as it increases and decreases.

To better understand the relation between time of day and sample concentration in historical samples (all samples prior to September 2018), the median concentration for filtered manganese and filtered zinc for hourly sample-collection intervals were examined (fig. 10). The high and low flow variation in the data was removed by excluding all samples associated with the runoff period, typically March through June, and winter samples, which could be affected by ice formation and thaw, November through February. After removal of the high 

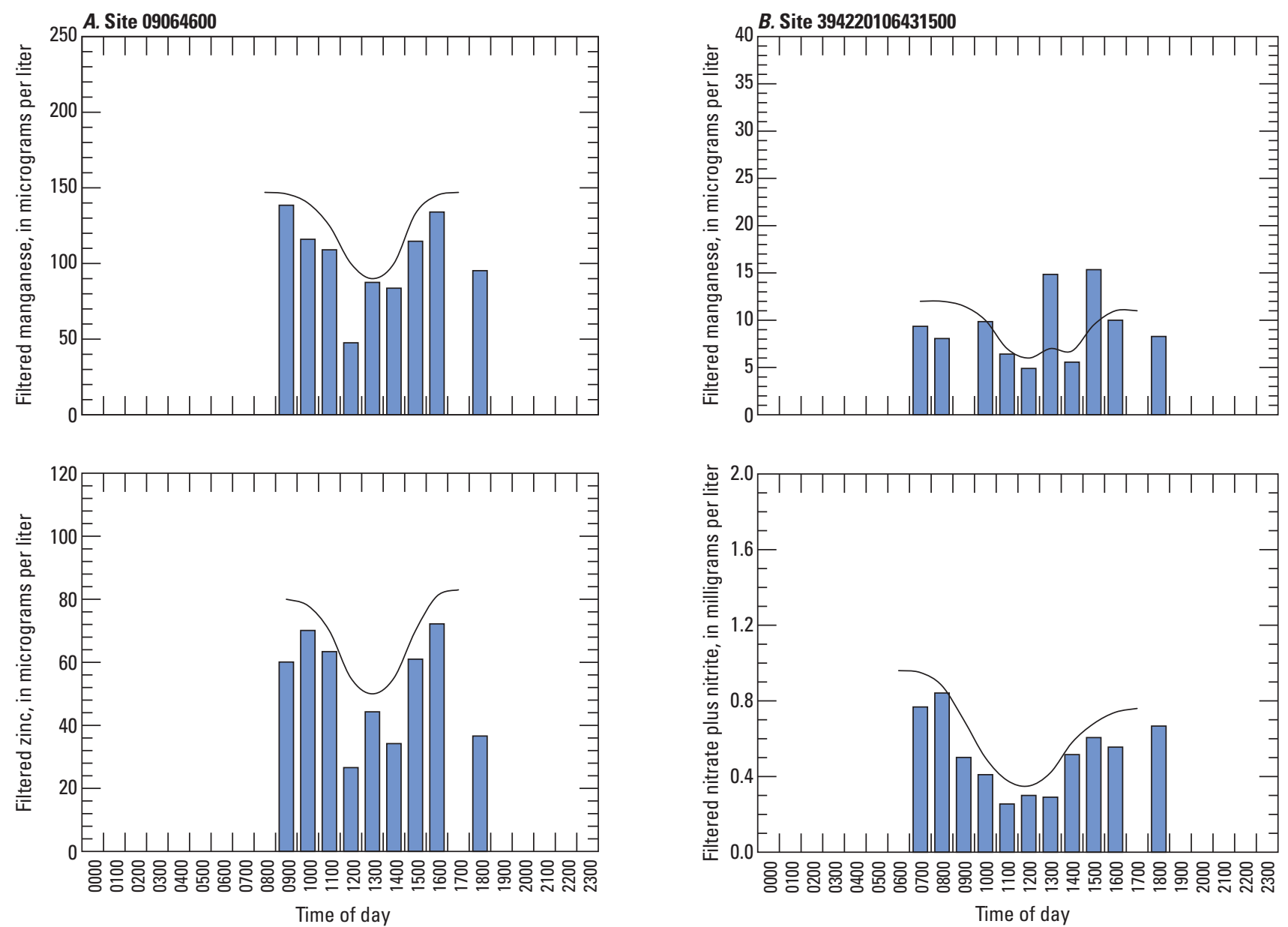

EXPLANATION

Historical samples, July - October

- Approximate trend line (hand drawn)

Figure 10. Median historical filtered manganese, filtered zinc, and filtered nitrate plus nitrite concentration each hour for historical samples collected from July through October at sites $A, 09064600$ and $B, 394220106431500$, Eagle County, Colorado.

and low flow samples, the resulting diel pattern in the median concentration for filtered manganese and filtered zinc at site 09064600 , and filtered manganese and filtered nitrate plus nitrite at site 394220106431500 , is consistent with the diel pattern in the September 2018 samples (fig. 10). Higher concentrations occur in the early morning and late afternoon, with the minimum median concentration between 1100 and 1400 .

The management of sampling programs within a river basin can have a substantial effect on the resulting dataset. Data used to establish baseline conditions, assess water-quality standards, detect long-term trends, and evaluate remediation efforts, in the presence of diel variability, may potentially be misinformative and lead to inaccurate conclusions. Diel variability is present in the Eagle River Basin and potentially affects the resulting data. The concentrations of numerous parameters appear to have a wide range of concentrations during the course of a day, as much as 284 percent, in the case of filtered manganese (table 6).

\section{Relation Between Diel Cycling and Land Use}

Another aspect to warrant consideration when developing or managing a sampling program is land use, and the different effects land use can have on diel cycling. Water-quality sampling sites in this study were chosen to help inform of the potential effects different types of land use may have on the diel cycling in both nutrients and trace elements. The classified land use types in the Eagle River Basin are displayed in figure 11 . Based on the results of the water-quality monitoring deployments and the water-quality sampling, it is difficult to make any firm statements about how land use affects the diel cycling of nutrients and trace elements; however, some generalities can be discussed and warrant consideration when managing a water-quality sampling program. 
The diel cycling of nutrients has typically been related to systems with known nutrient inputs (Nimick and others, 2003, Gammons and others, 2015). These systems are usually near urban development and are associated with turf maintenance and treatment of wastewater. Site 09066325 was designed to capture as much urban land use as possible while restricting other land use inputs (fig. 11), such as those related to agriculture and mining. Nutrient levels were generally low at this site during the water-quality sampling in September 2018 (table 5). The site is located upstream from a nearby waste-water treatment facility and did not capture the effect the treatment facility may have on nutrient concentrations and the cycling of those nutrients. However, even at low concentrations upstream from the treatment facility, nitrate results showed diel cycling (table 5). Trace elements associated with the site were also low, and most were below reporting limits. The few detectable parameters did show some diel signal (table 6). Site 394220106431500 encompassed many urban areas as well as agricultural inputs (fig. 11). Nutrient concentrations were above reporting limits for most parameters, and strong diel cycles existed (table 5). Based on data in this study and available historical data, urban land use has a high potential for inducing nutrient diel cycling based on the number and type of human inputs to the system.

Agricultural land may introduce nutrients into streams and can cause different diel ranges of dissolved oxygen and $\mathrm{pH}$ because of enhanced biological activity from the nutrients. The application of fertilizers, livestock practices, and management of the land all affect how nutrients enter the water system near agricultural land use areas. This study did not isolate agricultural land use, and most of the agricultural land in the Eagle River Basin is downstream from the sites used in the study (fig. 11). However, based on the information available at site 394220106431500, it appears increases in nutrient concentrations cause larger variation in $\mathrm{pH}$ and dissolved oxygen because of increased photosynthesis and respiration (table 4; table 5). These larger amplitude swings in dissolved oxygen and $\mathrm{pH}$ can increase the amplitude of the diel cycle on nutrients (table 4) and trace elements (table 5) varying depending on the amount of dissolved oxygen and the $\mathrm{pH}$ in streams.

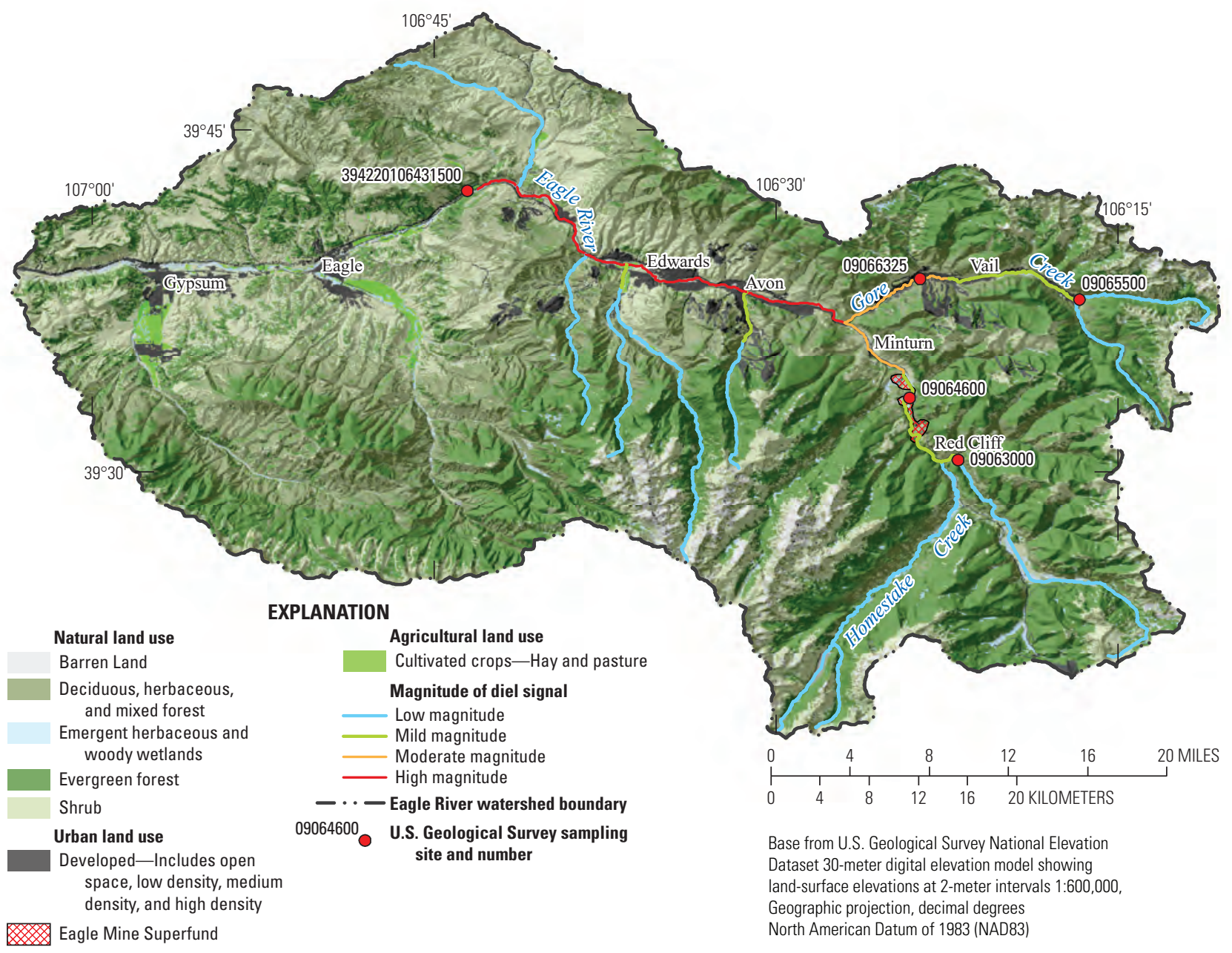

Figure 11. Land use in the Eagle River Basin, Eagle County, Colorado. 
Algal growth in the river system can affect the timing and magnitude of diel cycling in nutrients and, to a lesser degree, trace-element concentrations (through enhanced sorption surfaces on the streambed biota). This process can increase the magnitude of diel cycling in nutrients as more or less nutrients are being used up by the algae during the photosynthetic period of the day and affect the concentrations of nutrients in the water column at night when photosynthesis stops (Gammons and others, 2011). Nutrient inputs from various land uses help contribute to the timing and magnitude of the diel cycle as well. An example of this would be a nutrient input tending to be constant throughout the year. During colder periods of the year, the concentrations of nutrients may remain consistent in the input source, with a small diel signature associated with minor nutrient uptake from plants along the streambank and organisms using nutrients from the water column. However, once the water conditions are conducive to algal growth and algae begin to grow, the concentrations of nutrients can become more variable, and the magnitude of diel cycles also change.

If nutrient inputs remain constant during the algal growth period and more nutrients are being consumed, the magnitude of the range of observed diel concentrations will increase as maximum concentrations remain similar to before algal growth began. However, more nutrient consumption creates a lower minimum value. If nutrient inputs are changing throughout the day, the interaction becomes more complicated, and diel cycles also become more variable. In some cases, the diel cycle variability could result in concentrations unknowingly exceeding standard values for a stream segment. An example of this case could be a variable nutrient input monitored by discrete sampling and occurs during the typical daytime work period. Concentrations of these samples indicate nutrient concentrations are in an acceptable range; however, if there is active consumption of nutrients occurring during the sampling time frame, it may be misleading to what is happening during the rest of the day. Potentially, it is possible as photosynthesis stops at night, the concentrations of nutrients rise above standards. Also, increased inputs at night compared to the daytime could create higher than anticipated concentrations during the night because no photosynthesis is occurring to help consume nutrients in the water column.

The presence of diel cycling in trace elements related to natural inputs and historical mining has been well documented in literature. Nimick and others (2011), Gammons and others (2005), and Balistrieri and others (2012) have all documented large diel variation in streams near trace-element inputs, with a 900 percent change reported by Balistrieri and others (2012). The results presented herein at site 09064600 also confirm the presence of diel cycling of trace elements in the Eagle River below historical mining activity (fig. 11). This result indicates streams or stream segments located downstream from natural trace-element inputs and active or historical mining activity have high potential to exhibit larger ranges in diel cycles. However, based on the historical data collected and the results of this study, the presence of diel cycles in nutrients downstream from mining activity is most likely to be low, unless there is a known input of nutrients to the system associated with the mining activity.

Areas not falling into a land use designation of urban, mining affected, or agriculture are classified as natural land use. These areas have little human effects, and concentrations in these areas are predominately from natural sources. For the purposes of this study, site 09065500 and site 09063000 were used to assess the potential for diel signals associated with nature lands use designation (fig. 11). Historical data collected at these sites and the results of monitor deployments indicated concentrations of nutrients and trace elements from natural areas are low and many times below reporting limits (U.S. Geological Survey, 2019a). Because many concentrations are below reporting limits, it is difficult to assess a diel signal, and it is assumed the potential for a diel signal for nutrients and trace elements exists but is not visible because of method reporting levels. To illustrate and compare the difference between a natural land use site with minimal diel cycling of nutrients and trace elements and a site with documented diel cycling, $\mathrm{pH}$ and dissolved oxygen are plotted in figure 12 . The figure illustrates the larger diel variability in both $\mathrm{pH}$ and dissolved oxygen at site 394220106431500 , which is an indicator there is greater potential for diel cycling of nutrients and trace elements because there are more fluctuations in the values of $\mathrm{pH}$ and dissolved oxygen affecting diel cycling. In addition, this comparison provides an example human effects may have on water-quality parameters exhibiting diel cycling. Site 09065500 is an example of a site affected by only natural sources where the water-quality chemistry is affected mostly by geology and water quality and tends to be more stable, which is reflected in the reduced variability in $\mathrm{pH}$ and dissolved oxygen (fig. 12).

Seasonal effects on diel cycling are not well documented in the Eagle River Basin; winter base flow and snowmelt runoff periods are not documented and appear to have some effect on diel cycles during those periods. However, when streamflows are low and stable, there is evidence diel cycling of nutrients and trace elements have occurred historically and continue to occur in the Eagle River Basin. The potential to detect diel cycling is affected by numerous factors, including background conditions (geology), historical land use, and current land use, and as long as there are temperature gradients and photosynthesis occurring in streams, diel cycles will be present. When feasible, the potential of diel cycling warrants consideration, or at a minimum, diel cycling be recognized as a component of the river system dynamic and the potential consequences diel cycles may have in river management decisions. 

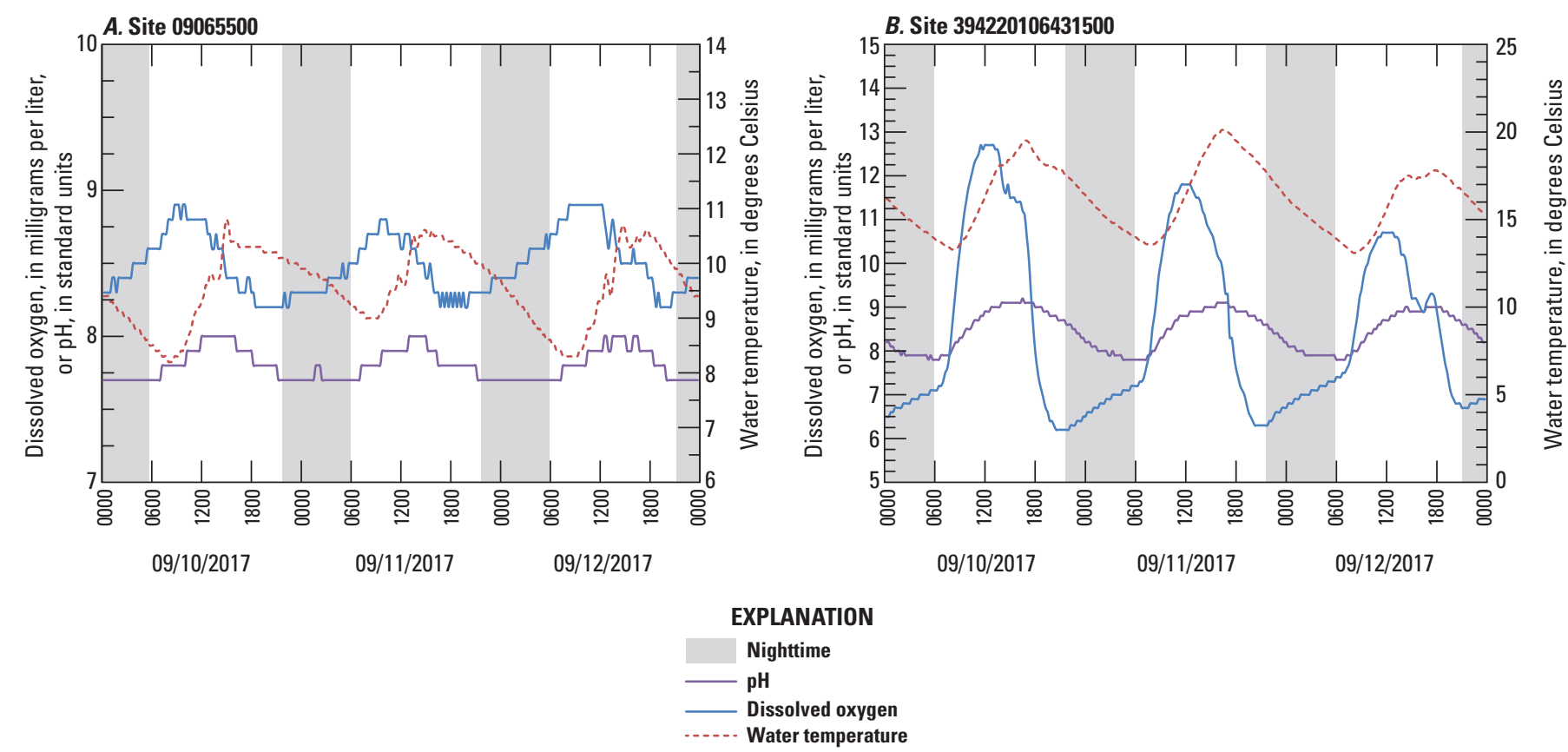

Figure 12. Water-quality monitoring data from September 10-September 12, 2017, comparing pH (purple), dissolved oxygen (dark blue), and water temperature (dashed red) at sites $A, 09065500$ and B, 394220106431500, Eagle County, Colorado.

\section{Summary}

Diel cycles are known to occur in all types of waters; historically, there has been more interest in streams and watersheds having actively been mined or having undergone mitigation from mining activities. Increasing literature indicate routine water samples may not provide an accurate snapshot in concentrations of trace elements and nutrients, and diel behavior in neutral to alkaline $\mathrm{pH}$ ranges is independent of streamflow variability and concentration. Periodic water-quality samples are useful in capturing a snapshot of the instream condition, in cases where a diel cycle exists; however, they can be misleading and potentially fail to capture the entire range of variability throughout the day and night.

Extensive historical water-quality data were collected in the Eagle River Basin during daylight hours. However, no data were collected throughout the nighttime period, making the evaluation of diel cycles impossible. To assess the importance diel cycling within the Eagle River Basin, the U.S. Geological Survey (USGS) - in cooperation with Eagle River Watershed Council - developed a study to assess diel cycles in waterquality properties at multiple locations within the basin and then to provide a preliminary quantification of the magnitude of change during the diel cycle for selected constituents.

The determination of diel cycles in the Eagle River Basin were approached using multiple methodologies during late summer and early fall river conditions. Multiparameter sondes at five sites were deployed in 2017 to evaluate the waterquality field parameters and determine if conditions were favorable for the diel cycling of trace elements and nutrients. Additionally, a detailed water-quality sampling, targeting nutrients and trace elements, was completed in the fall 2018 at three of the five sites to confirm the presence or absence of diel cycling and quantify the magnitude of daily variation.

The water-quality monitoring data were evaluated at five USGS streamgage sites (09065500, Gore Creek at Upper Station, near Minturn, Colorado, 09063000, Eagle River at Red Cliff, Colorado, 09064600, Eagle River near Minturn, Colorado, 09066325, Gore Creek above Red Sandstone Creek at Vail, Colorado, and 394220106431500, Eagle River below Milk Creek near Wolcott, Colorado) after approximately two-month deployments in the late summer, early fall 2017. Assessment of the environmental conditions through waterquality properties (streamflow, water temperature, specific conductance, dissolved oxygen, and $\mathrm{pH}$ ) along with photosynthetically active radiation allowed for interpretation regarding the potential for diel cycles at each site.

Streamflow and specific conductance maintained an inverse relation at all water-quality monitoring sites through the 2017 deployment period with a decrease in streamflow and increase in specific conductance. Water temperature and dissolved oxygen also inversely mirrored each other. The median water temperature at most water-quality sites was near 10.0 degrees Celsius $\left({ }^{\circ} \mathrm{C}\right)$ with minimum temperatures near $2.0^{\circ} \mathrm{C}$ degrees and maximum temperatures near $18.0^{\circ} \mathrm{C}$. Site 394220106431500 had the highest median temperature of $14.6^{\circ} \mathrm{C}$ and was the only site to exceed $20.0^{\circ} \mathrm{C}$ during the deployment. The water-quality monitoring sites had a median dissolved oxygen concentration 
between 8.0 and 9.0 milligrams per liter $(\mathrm{mg} / \mathrm{L})$. The maximum and minimum dissolved oxygen concentrations were at site 394220106431500 , ranging from 6.2 to $12.7 \mathrm{mg} / \mathrm{L}$. Visible algae and vegetation growth at this site indicated oxygen production from photosynthesis and consumption from respiration were resulting in larger diel variation at this site. The daily variations in $\mathrm{pH}$ during the deployment period were smaller at water-quality sites with less algae and aquatic plant growth, with variation of less than 0.5 standard units. The largest range in $\mathrm{pH}$ was measured at site 394220106431500 , ranging from 7.8 to 9.2 standard units, a variation of 3 to 5 times greater than other deployment water-quality sites. Photosynthetically active radiation values ranged from 0.0 micromoles per square meter per second during the nighttime period to about 2,300 micromoles per square meter per second during the middle of the day at the deployment water quality sites. Higher values occurred earlier in the deployment and slowly decreasing toward the end of the deployment, which contributed to the sun migrating to a lower latitude.

During the fall 2018, water-quality samples were collected every 4 to 5 hours at water-quality sites 09064600 and 394220106431500, and two samples (targeting the maximum and minimum $\mathrm{pH}$ values, indicated by the 2017 monitor deployments) were collected at site 09066325 . Water parameters, nutrients, and trace elements were collected and analyzed during the sampling. Steady-state streamflow conditions were important during the sampling period to ensure the minimal effect from streamflow variation on the diel variation of instream conditions. Streamflow remained stable during the sampling period. Site 09064600 had the largest percentage change of 6.1 percent $\left(2.0\right.$ cubic feet per second $\left[\mathrm{ft}^{3} / \mathrm{s}\right.$ ], ranging from 33 to $35 \mathrm{ft}^{3} / \mathrm{s}$ ). Streamflow varied 2.2 percent at site $09066325\left(0.3 \mathrm{ft}^{3} / \mathrm{s}\right.$, ranging from 13.4 to $\left.13.7 \mathrm{ft}^{3} / \mathrm{s}\right)$. Site 394220106431500 had more streamflow than the other water-quality sites and varied 5.3 percent $\left(4.0 \mathrm{ft}^{3} / \mathrm{s}\right.$, ranging from 76 to $80 \mathrm{ft}^{3} / \mathrm{s}$ ).

Ammonia, nitrate, nitrite, orthophosphate, and phosphorus were among the nutrients evaluated at site 09064600 , 09066325, and 394220106431500. Almost all nutrients sampled for at water-quality sites 09064600 and 09066325 were below reporting level, and diel cycle on these parameters could not be assessed. However, there was some variation in total nitrogen at site 09064600 . Site 09066325 had variation in total nitrogen, with much of that variation occurring as nitrate where there was a 57 percent diel change, ranging from 0.14 to $0.22 \mathrm{mg} / \mathrm{L}$. The most downstream site, 394220106431500 , had measurable concentrations in all nutrients and appreciable diel cycles. The largest percent diel change was 179 percent in nitrate plus nitrite, ranging from 0.24 to $0.67 \mathrm{mg} / \mathrm{L}$. The majority of this change is from nitrate, where 175 percent diel change was observed, ranging from 0.24 to $0.66 \mathrm{mg} / \mathrm{L}$. Additional notable nutrients were orthophosphate and phosphorus with 71.4 percent diel change (ranging from 0.07 to $0.12 \mathrm{mg} / \mathrm{L}$ ) and 50 percent diel change (ranging from 0.10 to $0.15 \mathrm{mg} / \mathrm{L}$ ), respectively. Maximum concentrations occurred prior to midday for most nutrients, decreased through the afternoon and evening, and increased during the night. The pattern is consistent with nutrient uptake in response to daytime photosynthesis along with biologically driven denitrification and nitrification cycles.

Numerous trace elements were evaluated at water-quality sites 09064600,09066325 , and 394220106431500. Most trace elements were above the reporting limit at site 09064600 . Site 09066325 had five trace elements above the reporting limit, including filtered barium, total recoverable iron, filtered and total manganese, and filtered selenium. Most trace elements had values above the reporting limit at site 394220106431500 .

Noteworthy diel cycles included filtered zinc (64.5 percent diel change, ranging from 38.3 to 63.0 micrograms per liter $[\mu \mathrm{g} / \mathrm{L}])$, total arsenic (50 percent diel change, ranging from 0.20 to $0.30 \mu \mathrm{g} / \mathrm{L}$ ), and filtered copper (41.4 percent diel change, ranging from 0.99 to $1.40 \mu \mathrm{g} / \mathrm{L}$ ). Total recoverable iron and total manganese were the most notable trace elements at site 09066325 with greater than 94.0 percent diel change (ranging from less than 10.0 to $19.4 \mu \mathrm{g} / \mathrm{L}$ ) and 50.0 percent diel change (ranging from 1.80 to $2.70 \mu \mathrm{g} / \mathrm{L}$ ), respectively. Site 394220106431500 had the largest measured percent diel change of the three water-quality sites with percent diel changes values ranging from 11.6 to 284 percent. Some appreciable trace elements at this site included filtered zinc (greater than 37.5 percent diel change, ranging from less than 4.00 to $5.50 \mu \mathrm{g} / \mathrm{L}$ ), filtered copper (42.9 percent change, ranging from 0.98 to $1.40 \mu \mathrm{g} / \mathrm{L}$ ), and total manganese (101 percent diel change, ranging from 9.70 to $19.5 \mu \mathrm{g} / \mathrm{L}$ ). The highest measured percentage diel change was measured in filtered manganese (284 percent diel change, ranging from 2.84 to $10.9 \mu \mathrm{g} / \mathrm{L}$ ). Although there was some variation in the timing of the peak, many trace elements had their maximum values during the night. However, there were some exceptions: Filtered copper, total arsenic, filtered selenium had maximum concentrations in the mid to late afternoon.

Analysis of historical data showed evidence of diel cycling. Historical samples collected from July through October were used to identify diel cycling in base-flow conditions. The resulting diel pattern in the median concentration for filtered manganese and filtered zinc at water-quality site 09064600 and filtered manganese and filtered nitrate plus nitrite at water-quality site 39422016431500 were consistent with the diel pattern in the September 2018 samples, and indicate time of day can bias sampling results even during daylight hours.

Diel cycling in the Eagle River Basin appears to be driven primarily by instream, biological processes. However, land use, particularly human effects downstream from urban areas, mining, and agriculture, may affect these processes. The presence of algae can increase the effects of photosynthesis allowing for greater fluctuations in dissolved oxygen and $\mathrm{pH}$. The presence of increased algae also affects the timing of nutrient uptake, with more nutrients being used during the day as photosynthesis is active and reduces at night during respiration creating larger diel magnitudes in diel cycles when more algae is present. This process was evident at site 394220106431500 
where the largest magnitude in diel variation was measured in most nutrients. Areas with increased algal growth also have the potential to create larger diel ranges in trace elements. The increased underwater surface area created by algae has the potential to allow more sorption locations for trace elements to bind to which could create a greater range in diel concentrations, evident in some of the largest percentage diel change values (284 percent in filtered manganese) in trace elements at site 394220106431500. Diel cycling in trace elements are also affected by natural and human inputs, most notably, historical or current mining activity, and stream segment near these inputs are more likely to exhibit larger ranges in diel variation.

The management of sampling programs within a river basin can have a substantial effect on establishing baseline conditions, assessing water-quality standards, detecting longterm trends, and evaluating remediation efforts. In the presence of diel variability, data may potentially be misinformative and lead to inaccurate conclusions. Nutrient and trace-element diel variability is present in the Eagle River Basin. The concentrations of numerous parameters appear to have a wide range of values, as much as 284 percent. Seasonal components are not well documented; however, when flows are low and stable, there is evidence diel cycling of trace elements and nutrients are occurring and occurred historically. When feasible, the potential of diel cycling warrants consideration in sample design to account for the potential of diel cycles, or at a minimum, be recognized as a component of the river dynamic and the potential consequences diel cycles may have in river management decisions.

\section{References Cited}

Angove, M.J., Johnson, B.B., and Wells, J.D., 1998, The influence of temperature on the adsorption of cadmium(II) and cobalt(II) on kaolinite: Journal of Colloid and Interface Science, v. 204, no. 1, p. 93-103, accessed August 2019, at https://doi.org/10.1006/jcis.1998.5549.

Apogee Instruments, [2019], Clear sky calculator for quantum sensors, Apogee Instruments web page, accessed August 2019, at https://clearskycalculator.com/quantumsensor.htm.

Bäckström, M., Börjesson, E., and Karlsson, S., 2002, Diurnal variations of abiotic parameters in a stream, recipient for drainage water in Ranstad, southwest Sweden: Journal of Environmental Monitoring, v. 4, no. 5, p. 772-777. [Also available at https://doi.org/10.1039/B201659A.]

Balistrieri, L.S., and Murray, J.W., 1986, the surface chemistry of sediments from the Panama Basin-The influence of Mn oxides on metal adsorption: Geochimica et Cosmochimica Acta, v. 50, no. 10, p. 2235-2243, accessed August 2019, at https://doi.org/10.1016/0016-7037(86)90078-5.
Balistrieri, L.S., Nimick, D.A., and Mebane, C.A., 2012, Assessing time-integrated dissolved concentrations and predicting toxicity of metals during diel cycling in streams: The Science of the Total Environment, v. 425, p. 155-168, accessed September 2019, at https://doi.org/10.1016/ j.scitotenv.2012.03.008.

Benjamin, M.M., and Leckie, J.O., 1981, Multiple site adsorption for $\mathrm{Cd}, \mathrm{Cu}, \mathrm{Zn}$, and $\mathrm{Pb}$ on amorphous iron oxyhydroxide: Journal of Colloid and Interface Science, v. 79, no. 1, p. 209-221, accessed August 2019, at https://doi.org/ 10.1016/0021-9797(81)90063-1.

Borman, C.J., Sullivan, B.P., Eggleston, C.M., and Colberg, P.J.S., 2010, Is iron redox cycling in a high altitude watershed photochemically or thermally driven?: Chemical Geology, v. 269, no. 1-2, p. 33-39, accessed August 2019, at https://doi.org/10.1016/j.chemgeo.2009.07.011.

Bourg, A.C.M., and Bertin, C., 1996, Diurnal variations in the water chemistry of a river contaminated by heavy metalsNatural biological cycling and anthropic influence: Water, Air, and Soil Pollution, v. 86, no. 1-4, p. 101-116, accessed August 2019, at https://doi.org/10.1007/BF00279148.

Brick, C.M., and Moore, J.N., 1996, Diel variation of trace metals in the upper Clark Fork River, Montana: Environmental Science \& Technology, v. 30, no. 6, p. 1953-1960, accessed September 2019, at https://doi.org/10.1021/es9506465.

Catts, J.G., and Langmuir, D., 1986, Adsorption of $\mathrm{Cu}, \mathrm{Pb}$ and $\mathrm{Zn}$ by $\mathrm{MnO}_{2}$ - Applicability of the site binding-surface complexation model: Applied Geochemistry, v. 1, no. 2, p. 255-264, accessed August 2019, at https://doi.org/ 10.1016/0883-2927(86)90010-7.

Collienne, R.J., 1983, Photoreduction in the epilimnion of acidic lakes-American Society of Limnology and Oceanography: Inc., v. 280, no. 1, p. 83-100, accessed August 2019, at https://doi.org/10.4319/1o.1983.28.1.0083.

Colorado Department of Public Health and Environment and U.S. Environmental Protection Agency, 2008, Eagle Mine Superfund Site, Eagle County, Colorado: Colorado Department of Public Health and the U.S. Environmental Protection Agency, Third Five-Year Review Report, 88 p., accessed September 2019, at https://semspub.epa.gov/work/ HQ/179809.pdf.

Colorado Department of Public Health and Environment and U.S. Environmental Protection Agency, 2018, Eagle Mine Superfund Site, Eagle County, Colorado: Colorado Department of Public Health and the U.S. Environmental Protection Agency, Fifth Five-Year Review Report, 73 p., accessed September 2019, at https://semspub.epa.gov/work/ 08/100005465.pdf. 
Dawson, J.J.C., Billett, M.F., and Hope, D., 2001, Diurnal variations in the carbon chemistry of two acidic peatland streams in north-east Scotland: Freshwater Biology, v. 46, no. 10, p. 1309-1322, accessed August 2019, at https://doi.org/10.1046/j.1365-2427.2001.00751.x.

Dzomback, D.A., and Morel, F.M.M., 1990, Surface complexation modeling: Hoboken, N.J., John Wiley and Sons, $105 \mathrm{p}$.

Fein, J.B., Martin, A.M., and Wightman, P.G., 2001, Metal adsorption onto bacterial surfaces-Development of a predictive approach: Geochimica et Cosmochimica Acta, v. 65, no. 23, p. 4267-4273, accessed August 2019, at https://doi.org/10.1016/S0016-7037(01)00721-9.

Fishman, M.J., 1993, Methods of analysis by the U.S. Geological Survey National Water Quality LaboratoryDetermination of inorganic and organic constituents in water and fluvial sediments: U.S. Geological Survey Open-File Report 93-125, 217 p., accessed June 2019, at https://doi.org/10.3133/ofr93125.

Fishman, M.J., and Friedman, L.C., 1989, Methods for determination of inorganic substances in water and fluvial sediments: U.S. Geological Survey Techniques of Water-Resources Investigations, book 5, chap. A1, 545 p., accessed June 2019, at https://doi.org/10.3133/twri05A1.

Forget, M., Carignan, R., and Hudon, C., 2009, Influence of diel cycles of respiration, chlorophyll, and photosynthetic parameters on the summer metabolic balance of temperate lakes and rivers: Canadian Journal of Fisheries and Aquatic Sciences, v. 66, no. 7, p. 1048-1058, accessed August 2019, at https://doi.org/10.1139/F09-058.

Fowle, D.A., and Fein, J.B., 2000, Experimental measurements of the reversibility of metal-bacteria adsorption reactions: Chemical Geology, v. 168, no. 1-2, p. 27-36, accessed June 2019, at https://doi.org/10.1016/S00092541(00)00188-1.

Fuller, C.C., and Davis, J.A., 1989, Influence of coupling of sorption and photosynthetic processes on trace elements cycles in natural waters: Nature, v. 340 , no. 6228 , p. 52-54, accessed September 2019, at https://doi.org/10.1038/ $340052 \mathrm{a} 0$.

Fuller, C.C., Davis, J.A., and Waychunas, G.A., 1993, Surface chemistry of ferrihydrite-Part 2, Kinetics of arsenate adsorption and coprecipitation: Geochimica et Cosmochimica Acta, v. 57, no. 10, p. 2271-2282, accessed August 2019, at https://doi.org/10.1016/00167037(93)90568-H.
Fuller, C.C., and Harvey, J.W., 2000, Reactive uptake of trace metals in the hyporheic zone of a mining-contaminated stream, Pinal Creek, Arizona: Environmental Science \& Technology, v. 34, no. 7, p. 1150-1155, accessed August 2019, at https://doi.org/10.1021/es990714d.

Gammons, C.H., Babcock, J.N., Parker, S.R., and Poulson, S.R., 2011, Diel cycling and stable isotopes of dissolved oxygen, dissolved inorganic carbon, and nitrogenous species in a stream receiving treated municipal sewage: Chemical Geology, v. 283, p. 44-55, accessed September 2019, at https://doi.org/10.1016/j.chemgeo.2010.07.006.

Gammons, C.H., Duaime, T.E., Parker, S.R., Poulson, S.R., and Kennelly, P., 2010, Geochemistry and stable isotope investigation of acid mine drainage associated with abandoned coal mines in central Montana, USA: Chemical Geology, v. 269, no. 1-2, p. 100-112, accessed August 2019, at https://doi.org/10.1016/j.chemgeo.2009.05.026.

Gammons, C.H., Nimick, D.A., Parker, S.R., Cleasby, T.E., and McCleskey, R.B., 2005, Diel behavior of iron and other heavy metals in a mountain stream with acidic to neutral $\mathrm{pH}$-Fisher Creek, Montana, USA: Geochimica et Cosmochimica Acta, v. 69, no. 10, p. 2505-2516, accessed August 2019, at https://doi.org/10.1016/j.gca.2004.11.020.

Gammons, C.H., Nimick, D.A., and Parker, S.R., 2015, Diel cycling of trace elements in streams draining mineralized areas-A review: Applied Geochemistry, v. 57, p. 35-44, accessed August 2019, at https://doi.org/10.1016/ j.apgeochem.2014.05.008.

Garbarino, J.R., Kanagy, L.K., and Cree, M.E., 2005, Determination of elements in natural-water, biota, sediment and soil samples using collision/reaction cell inductively coupled plasma-mass spectrometry: U.S. Geological Survey Techniques and Methods, book 5, sec. B, chap. 1, 88 p., accessed September 2019, at https://pubs.usgs.gov/tm/ 2006/tm5b1/.

Grover, N.C., and Harrison, A.W., 1966, Stream flowMeasurements: Dover, Records and Their Uses, 363 p.

Guasch, H., Armengol, J., Martí, E., and Sabater, S., 1998, Diurnal variation in dissolved oxygen and carbon dioxide in two low-order streams: Water Research, v. 32, no. 4, p. 1067-1074, accessed September 2019, at https://doi.org/ 10.1016/S0043-1354(97)00330-8.

Harris, S.H., and Smith, R.L., 2009, In situ measurements of microbially-catalyzed nitrification and nitrate reduction rates in an ephemeral drainage channel receiving water from coalbed natural gas discharge, Powder River Basin, Wyoming, USA: Chemical Geology, v. 267, no. 1-2, p. 77-84, accessed August 2019, at https://doi.org/10.1016/ j.chemgeo.2009.01.028. 
Harrison, J.A., Matson, P.A., and Fendorf, S.A., 2005, Effects of a diel oxygen cycle on nitrogen transformations and greenhouse gas emissions in a eutrophied subtropical stream: Aquatic Sciences, v. 67, no. 3, p. 308-315, accessed August 2019, at https://yaquivalley.stanford.edu/pdf/ Harrison_et_al_2005.pdf.

Hessen, D.O., Henrikson, A., and Smelhus, A.M., 1997, Seasonal fluctuations and diurnal oscillations in nitrate of a heathland brook: Water Research, v. 31, no. 7, p. 1813-1817, accessed September 2019, at https://doi.org/ 10.1016/S0043-1354(97)00010-9.

Hoffman, G.L., Fishman, M.J., and Garbarino, J.R., 1996, Methods of analysis by the U.S. Geological Survey National Water Quality Laboratory-In bottle acid digestion of whole water samples: U.S. Geological Survey Open-File Report 96-225, 28 p., accessed August 2019, at https://doi.org/10.3133/ofr96225.

Johnson, C.A., Leinz, R.W., Grimes, D.J., and Rye, R.O., 2002, Photochemical changes in cyanide speciation in drainage from a precious metal ore heap: Environmental Science \& Technology, v. 36, no. 5, p. 840-845, accessed August 2019, at https://doi.org/10.1021/es011064s.

Johnson, L.T., and Tank, J.L., 2009, Diurnal variations in dissolved organic matter and ammonium uptake in six open-canopy streams: Journal of the North American Benthological Society, v. 28, no. 3, p. 694-708, accessed August 2019, at https://doi.org/10.1899/08-107.1.

Kent, R., Belitz, K., and Burton, C.A., 2005, Algal productivity and nitrate assimilation in an effluent dominated concrete lined stream: Journal of the American Water Resources Association, v. 41, no. 5, p. 1109-1128, accessed September 2019, at https://doi.org/10.1111/j.1752-1688.2005.tb03788.x.

Loperfido, J.V., Just, C.L., and Schnoor, J.L., 2009, Highfrequency diel dissolved oxygen stream data modeled for variable temperature and scale: Journal of Environmental Engineering, v. 135, no. 12, p. 1250-1256, accessed October 2019, at https://doi.org/10.1061/(ASCE)EE.19437870.0000102 .

Lorens, R.B., 1981, Sr, Cd, Mn, Co distribution coefficients in calcite as a function of calcite precipitation rate: Geochimica et Cosmochimica Acta, v. 45, no. 4, p. 553-561, accessed, September 2019, at https://doi.org/ 10.1016/0016-7037(81)90188-5.

Lundquist, J.D., and Cayan, D., 2002, Seasonal and spatial patterns in diurnal cycles in streamflow in the western United States: Journal of Hydrometeorology, v. 3, no. 5, p. 591-603, accessed July 2019, at https://doi.org/10.1175/ 1525-7541(2002)003<0591:SASPID>2.0.CO;2.
Machesky, M.L., 1990, Influence of temperature on ion adsorption by hydrous metal oxides, in Chemical modeling of aqueous systems II: American Chemical Symposium Series, v. 416, chap. 46, p. 282-292, accessed September 2019, at https://doi.org/10.1021/bk-1990-0416.ch022.

McKnight, D.M., and Bencala, K.E., 1988, Diel variations in iron chemistry in an acidic stream in the Colorado Rocky Mountains, USA: Arctic and Alpine Research, v. 20, no. 4, p. 492-500, accessed August 2019, at https://doi.org/ 10.2307/1551347.

McKnight, D.M., Kimball, B.A., and Bencala, K.E., 1988, Iron photoreduction and oxidation in an acidic mountain stream: Science, v. 240, no. 4852, p. 637-640, accessed August 2019, at https://doi.org/10.1126/science.240.4852.637.

McKnight, D.M., Kimball, B.A., and Runkel, R.L., 2001, $\mathrm{pH}$ dependence of iron photoreduction in a rocky mountain stream affected by acid mine drainage: Hydrological Processes, v. 15, no. 10, p. 1979-1992, accessed September 2019, at https://doi.org/10.1002/hyp.251.

Mueller, D.K., Schertz, T.L., Martin, J.D., and Sandstrom, M.W., 2015, Design, analysis, and interpretation of field quality-control data for water-sampling projects: U.S. Geological Survey Techniques and Methods, book 4, chap. C4, 54 p., accessed September 2017, at https://doi.org/10.3133/tm4C4.

Mulholland, P.J., Thomas, S.A., Valett, H.M., Webster, J.R., and Beaulieu, J., 2006, Effects of light on $\mathrm{NO}_{3}{ }^{-}$uptake in small forested streams - Diurnal and day-to-day variations: Journal of the North American Benthological Society, v. 25, no. 3, p. 583-595, accessed October 2019, at https://doi.org/ 10.1899/0887-3593(2006)25[583:EOLONU]2.0.CO;2.

Nimick, D.A., Gammons, C.H., Cleasby, T.E., Madison, J.P., Skaar, D., and Brick, C.M., 2003, Diel cycles in dissolved metal concentrations in streams - Occurrence and possible causes: Water Resources Research, v. 39, no. 9, p. 1249, accessed June 2019, at https://doi.org/10.1029/ 2002WR001571.

Nimick, D.A., Gammons, C.H., and Parker, S.R., 2011, Diel biogeochemical processes and their effect on the aqueous chemistry of streams-A review: Chemical Geology, v. 233, no. 1-2, p. 3-17, accessed June 2019, at https://doi.org/ 10.1016/j.chemgeo.2010.08.017.

Nimick, D.A., Moore, J.M., Dalby, C.E., and Savka, M.W., 1998, The fate of geothermal arsenic in the Madison and Missouri Rivers, Montana and Wyoming: Water Resources Research, v. 34, no. 11, p. 3051-3067, accessed June 2019, at https://doi.org/10.1029/98WR01704.

Odum, H.T., 1956, Primary production in flowing water: Limnology and Oceanography, v. 2, no. 2, p. 85-97, accessed September 2109, at https://doi.org/10.4319/lo.1956.1.2.0102. 
Parker, S.R., Gammons, C.H., Pedrozo, F.L., and Wood, S.A., 2008, Diel changes in metal concentrations in a geogenically acidic river-Rio Agrio, Argentina: Journal of Volcanology and Geothermal Research, v. 178, no. 2, p. 213-223, accessed August 2019, at https://doi.org/ 10.1016/j.jvolgeores.2008.06.029.

Patton, C.J., and Kryskall, J.R., 2011, Colorimetric determination of nitrate plus nitrite in water by enzymatic reduction, automated discrete analyzer methods: U.S. Geological Survey Techniques and Methods, book 5, chap. B8, 34 p., accessed September 2019, at https://doi.org/10.3133/tm5B8.

Patton, C.J., and Truitt, E.P., 2000, Methods of analysis by the U.S. Geological Survey National Water Quality LaboratoryDetermination of ammonium plus organic nitrogen by a Kjeldahl digestion method and an automated photometric finish that includes digest cleanup by gas diffusion: U.S. Geological Survey Open-File Report 00-170, 31 p., accessed June 2019, at https://doi.org/10.3133/ofr00170.

Pritt, J.Q., and Raese, J.W., 1992, Quality assurance/quality control manual: U.S. Geological Survey Open-File Report 92-0495, 33 p., accessed July 2019, at https://doi.org/ $10.3133 /$ ofr92495.

Radtke, D.B. White, A.F., Davis, J.V., and Wilde, F.D., 1998, National field manual for the collection of waterquality data-Dissolved oxygen: U.S. Geological Survey Techniques of Water-Resources Investigations, book 9, chap. A6, sect. 6.2 [variously paged]. [Also available at https://doi.org/10.3133/tm9A6.2.]

Raymond, P.A., Caraco, N.F., and Cole, J.J., 1997, Carbon dioxide concentration and atmospheric flux in the Hudson River: Estuaries, v. 20, p. 381-390, accessed, October 2019, at https://doi.org/10.2307/1352351.

Roberts, B.J., and Mulholland, P.J., 2007, In-stream biotic control on nutrient biogeochemistry in a forested stream, West Fork of Walker Branch: Journal of Geophysical Research, v. 122, no. G4, no. G4, p. 1-11, accessed September 2019, at https://doi.org/10.1029/2007JG000422.

Scott, D.T., McKnight, D.M., Voelker, B.M., and Hrncir, D.C., 2002, Redox processes controlling manganese fate and transport in a mountain stream: Environmental Science \& Technology, v. 36, no. 3, p. 453-459, accessed August 2019, at https://doi.org/10.1021/es010951s.

Seaber, P.R., Kapinos, F.P., and Knapp, G.L., 1987, Hydrologic unit maps: U.S. Geological Survey Water-Supply Paper 2294, 63 p., accessed June 2019, at https://doi.org/10.3133/wsp2294.

Shiller, A.M., Duan, S., van Erp, P., and Bianchi, T.S., 2006, Photo-oxidation of dissolved organic matter in river water and its effect on trace element speciation: Limnology and Oceanography, v. 51, no. 4, p. 1716-1728, accessed September 2019, at https://doi.org/10.4319/ 1o.2006.51.4.1716.
Smith, R.L., Repert, D.A., and Hart, C.P., 2009, Geochemistry of inorganic nitrogen in waters released from coalbed natural gas production wells in the Powder River Basin, Wyoming: Environmental Science \& Technology, v. 43, no. 7, p. 2348-2354, accessed October 2019, at https://doi.org/10.1021/es802478p.

Stumm, W., and Morgan, J.J., 1996, Aquatic geochemistry: Hoboken, N.J., John Wiley \& Sons, 1,024 p.

Sullivan, A.B., Drevar, J.I., and McKnight, D.M., 1998, Diel variation in element concentrations-Peru Creek, Summit County, Colorado: Journal of Geochemical Exploration, v. 64 , no. 1-3, p. 141-145, accessed September 2019, at https://doi.org/10.1016/S0375-6742(98)00027-2.

Tesoriero, A.J., and Pankow, J.F., 1995, Solid solution partitioning of $\mathrm{SR}^{2+}, \mathrm{Ba}^{2+}$, and $\mathrm{Cd}^{2+}$ to calcite: Geochimica et Cosmochimica Acta, v. 60, no. 6, p. 1053-1063, accessed August 2019, at https://doi.org/10.1016/00167037(95)00449-1.

Trivedi, P., and Axe, L., 2000, Modeling Cd and Zn sorption to hydrous metal oxides: Environmental Science \& Technology, v. 34, no. 11, p. 2215-2223, accessed August 2019, at https://doi.org/10.1021/es991110c.

Trivedi, P., and Axe, L., 2001, Predicting divalent metal sorption to hydrous Al, Fe, and Mn oxides: Environmental Science \& Technology, v. 35, no. 9, p. 1779-1784, accessed August 2019, at https://doi.org/10.1021/es001644+.

Tweto, O., comp., 1979, Geologic map of Colorado: U.S. Geological Survey State Geologic Map, scale 1:500,000 (reprinted). U.S. Geological Survey, [variously dated], National field manual for the collection of water-quality data: U.S. Geological Survey Techniques of WaterResources Investigations, book 9, chap. A1-A9, accessed June 2019, at https://doi.org/10.3133/twri09.

U.S. Geological Survey, 2002, Processing of water samples [Wilde, F.D., ed.]: U.S. Geological Survey Techniques of Water-Resources Investigations, book 9, chap A5, accessed June 2019, at https://doi.org/10.3133/twri09A5.

U.S. Geological Survey, 2010, Office of Water Quality Technical Memorandum 2010.07: accessed June 2019, at https://water.usgs.gov/admin/memo/QW/qw10.07.html.

U.S. Geological Survey, 2019a, USGS water data for the Nation: U.S. Geological Survey National Water Information System database, accessed June 2019, https://doi.org/ 10.5066/F7P55KJN.

U.S. Geological Survey, 2019b, USGS 09065500 Gore Creek at upper Station, near Minturn, CO, in USGS water data for the Nation: U.S. Geological Survey National Water Information System database, accessed May 23, 2019, at https://doi.org/10.5066/F7P55KJN. 
U.S. Geological Survey, 2019c, USGS 09063000 Eagle River at Redcliff, CO, in USGS water data for the Nation: U.S. Geological Survey National Water Information System database, accessed May 23, 2019, at https://doi.org/10.5066/ F7P55KJN.

Wagner, R.J., Boulger, R.W., Jr., Oblinger, C.J., and Smith, B.A., 2006, Guidelines and procedures for continuous water-quality monitors - Station operation, record computation, and data reporting: U.S. Geological Survey Techniques and Methods 1-D3, 51 p., 8 attachments, accessed July 2019, at https://doi.org/10.3133/tm1D3.

Warwick, J.J., 1986, Diel variation of in-stream nitrification: Water Research, v. 20, no. 10, p. 1325-1332, accessed October 2019, https://doi.org/10.1016/0043-1354(86)90165-X.
Western Regional Climate Center, 2019, Cooperative climatological data summaries, Colorado, accessed June 5, 2019, at https://wrcc.dri.edu/summary/Climsmco.html.

Wieder, R.K., 1994, Diel changes in iron(III)/iron(II) in effluent from constructed acid mine drainage treatment wetlands: Journal of Environmental Quality, v. 23, no. 4, p. 730-738, accessed July 2019, https://doi.org/10.2134/ jeq1994.00472425002300040017x.

Zachara, J.M., Cowan, C.E., and Resch, C.T., 1991, Sorption of divalent metals on calcite: Geochimica et Cosmochimica Acta, v. 55, no. 6, p. 1549-1562, accessed August 2019, https://doi.org/10.1016/0016-7037(91)90127-Q. 
Publishing support provided by the Science Publishing Network, Denver Publishing Service Center

For more information concerning the research in this report, contact the

Director, USGS Colorado Water Science Center

Box 25046, Mail Stop 415

Denver, CO 80225

(303) 236-4882

Or visit the Colorado Water Science Center website at https://www.usgs.gov/centers/co-water 
